INEL-96/0369

September 1996

\title{
Drop-in Capsule Testing of Plutonium-based Fuels in the Advanced Test Reactor
}

\author{
RECENED \\ DEC 191996 \\ OSTI
}

Gray S. Chang

John M. Ryskamp

William K. Terry

Richard G. Ambrosek

A. Joseph Palmer

Robert A. Roesener Laboratory 


\section{DISCLAIMER}

This report was prepared as an account of work sponsored by an agency of the United States Government. Neither the United States Government nor any agency thereof, nor any of their employees, makes any warranty, express or implied, or assumes any legal liability or responsibility for the accuracy, completeness, or usefulness of any information, apparatus, product, or process disclosed, or represents that its use would not infringe privately owned rights. Reference herein to any specific commercial product, process, or service by trade name, trademark, manufacturer, or otherwise does not necessarily constitute or imply its endorsement, recommendation, or favoring by the United States Government or any agency thereof. The views and opinions of authors expressed herein do not necessarily state or reflect those of the United States Government or any agency thereof. 


\section{DISCLAIMER}

Portions of this document may be illegible in electronic image products. Images are produced from the best available original document. 


\title{
DROP-IN CAPSULE TESTING OF PLUTONIUM-BASED FUELS IN THE ADVANCED TEST REACTOR
}

\author{
Gray S. Chang \\ John M. Ryskamp \\ William K. Terry \\ Richard G. Ambrosek \\ A. Joseph Palmer \\ Robert A. Roesener
}

September 1996

Idaho National Engineering Laboratory

Lockheed Martin Idaho Technologies Co.

P.O. Box 1625

Idaho Falls, ID 83415-3885

Prepared for the U. S. Department of Energy

Under DOE Idaho Operations Office

Contract DE-AC07-94ID13223 


\section{SUMMARY}

The most attractive way to dispose of weapons-grade plutonium (WGPu) is to use it as fuel in existing light water reactors (LWRs) in the form of mixed oxide (MOX) fuel - i.e., plutonia $\left(\mathrm{PuO}_{2}\right)$ mixed with urania $\left(\mathrm{UO}_{2}\right)$. Before U.S. reactors could be used for this purpose, their operating licenses would have to be amended. Numerous technical issues must be resolved before LWR operating licenses can be amended to allow the use of MOX fuel. The proposed weaponsgrade MOX fuel is unusual, even relative to ongoing foreign experience with reactor-grade MOX power reactor fuel. Some demonstration of the in-reactor thermal, mechanical, and fission gas release behavior of the prototype fuel will most likely be required in a limited number of test reactor irradiations. The application to license operation with MOX fuel must be amply supported by experimental data.

The Advanced Test Reactor (ATR) at the Idaho National Engineering Laboratory (INEL) is capable of playing a key role in the irradiation, development, and licensing of these new fuel types. The ATR is a 250-MW (thermal) LWR designed to study the effects of intense radiation on reactor fuels and materials. For 25 years, the primary role of the ATR has been to serve in experimental investigations for the development of advanced nuclear fuels. Both large- and small-volume test positions in the ATR could be used for MOX fuel irradiation. The ATR would be a nearly ideal test bed for developing data needed to support applications to license LWRs for operation with MOX fuel made from weapons-grade plutonium. Furthermore, these data can be obtained more quickly by using ATR instead of testing in a commercial LWR.

Our previous work ${ }^{1-4}$ in this area has demonstrated that it is technically feasible to perform MOX fuel testing in the ATR. This report documents our analyses of sealed drop-in capsules containing plutonium-based test specimens placed in various ATR positions. Analyses have been performed on a variety of drop-in capsules to resolve fundamental questions about the suitability of the ATR for a MOX fuel testing program. The test results from a MOX fuel testing program must give valid data from which to draw conclusions about MOX fuel performance in a commercial reactor. Also, the presence of MOX fuel test specimens in the ATR must not impair the ability of the reactor to perform simultaneous irradiations in other test locations, because only a relative few of the ATR's test locations would be occupied by MOX fuel specimens. Most important, the tests must not jeopardize the operating safety of the reactor.

The analyses included calculations of neutron fluxes and spectra, fuel burnup rates, heating rates, temperatures, and decay activities. Similar analyses using similar methods were performed 
for typical commercial reactors: a Pressurized Water Reactor (PWR), a Boiling Water Reactor (BWR), and a CANDU (heavy water) reactor. We compared the conditions in commercial reactors containing MOX fuel with the conditions available at various positions in the ATR. We are able to select certain ATR positions that achieve reasonable matches to typical commercial reactor conditions.

The information provided in this report will be useful for setting realistic MOX testing requirements, selecting the desired test locations, estimating the irradiation time required to achieve a desired burnup level, and ensuring that the capsule temperature limits will not be exceeded. With the models and methods that we have developed, the INEL is now able to quickly design and analyze drop-in capsules in the ATR. This will also reduce the time necessary to accomplish MOX fuel testing in the ATR.

A comparison of the neutronics behavior of a single PWR-type MOX fuel capsule in a large I-hole with the behavior of six such capsules in the same location shows the effects of selfshielding dramatically. The average heat generation and burnup when six capsules are placed in the I-hole are about $30 \%$ less than when only one capsule is present. Similar effects are produced when capsules are placed in nearby test locations. These results show vividly that it is essential to perform ATR neutronics calculations self-consistently, and that estimates of burnup and other neutronics parameters made from unperturbed flux data would be seriously in error.

Neutronics and thermohydraulics analyses of single PWR-type capsules in small and large B-holes and small, medium, and large I-holes show that a range of burnup rates can be achieved, although temperatures in the higher-flux locations would be excessive without the use of some mitigating technique, such as placement of hafnium shrouds around the capsules. Further conclusions on the effects of self-shielding are reached from these calculations; for example, heat generation and burnup rates do not increase proportionately when the $\mathrm{PuO}_{2}$ concentration in the fuel pellets is increased.

Calculations of the residual radioactivity and decay heat show that these quantities fall rapidly for about three weeks after the MOX fuel is removed from the reactor; they subside slowly thereafter.

A neutronics methodology that is consistent with the methodology used to analyze drop-in capsules in the ATR was developed to analyze commercial reactors. The same consistent and reasonably accurate method has been used to compute neutron flux spectra in typical PWR, BWR, 
and CANDU reactors, as well as in various ATR irradiation positions. The spectra in the ATR reflector are similar to those in CANDU reactors, but much softer than the spectra in commercial PWRs containing full MOX cores.

A brief description of the transport of irradiated MOX fuel specimens from the ATR to post-irradiation examination hot cells is also included in this report. The selection of the transport packaging depends on the characteristics of the specimens and on the facilities involved. 


\section{CONTENTS}

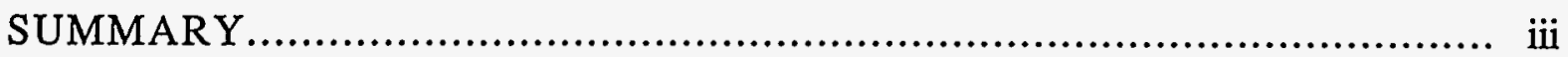

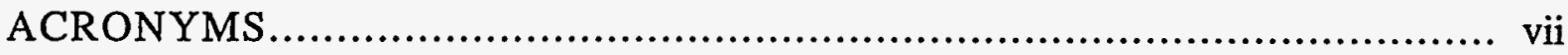

$1.0 \quad$ INTRODUCTION ............................................................ 1

2.0 FUEL TESTING IN THE ADVANCED TEST REACTOR............................. 5

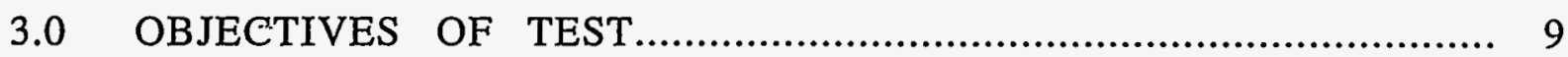

4.0 MECHANICAL DESIGN OF DROP-IN CAPSULES.............................. 12

5.0 NEUTRONICS AND THERMOHYDRAULICS STUDIES OF DROP-IN CAPSULES................................................................ 18

5.1 MOX Fuel in Large I-Holes................................................... 20

5.2 Single MOX Fuel Pins in I-Holes and B-Holes............................... 29

5.3 EMOX Fuel......................................................... 42

6.0 NEUTRONIC ANALYSIS OF COMMERCIAL REACTORS........................ 45

6.1 Weapons-Grade MOX Fuel Assembly Design Features......................... 45

6.2 Unit Cell and Checkerboard Assembly Models................................... 46

6.3 Unit Cell and Fuel Assembly Neutronic Characteristics.......................... 48

6.4 Mixed Fuel Assembly Burnup Analysis........................................... 55

6.5 Summary of PWR Analysis................................................. 56

6.6 BWR and CANDU Models................................................ 59

6.7 Comparison of ATR, PWR, BWR, and CANDU Neutron Flux Spectra..... 59

7.0 TRANSPORTATION OF IRRADIATED MOX FUEL SPECIMENS................ 69

7.1 Characteristics of the Specimens............................................... 69

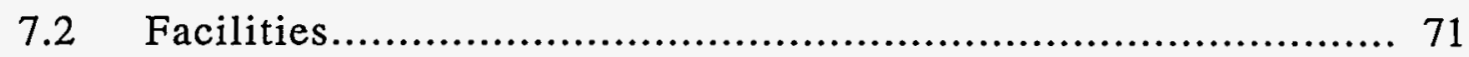

7.3 Transport Packaging Selection Summary....................................... 72

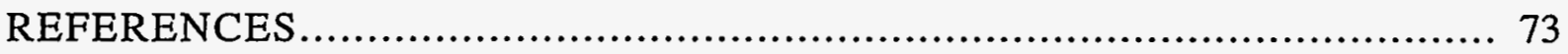




\section{ACRONYMS}

ASME

ATR

BDOGXS

BOC

BWR

CANDU

CBFAM

DOE

DOT

EFPD

EMOX

ENDF/B-V

EOC

FT

FY

GESMO

HMR

INEL

$\mathrm{K}_{\infty}$

LANL

LDRD

LEU

LLNL

LMITCO

LTA

LWR
American Society of Mechanical Engineers

Advanced Test Reactor

Burnup-Dependent One-Group Cross Sections

Beginning of Cycle

Boiling Water Reactor

Canadian Deuterium Uranium reactor

Checkerboard Fuel Assembly Model

Department of Energy

Department of Transportation

Effective Full-Power Days

Evolutionary Mixed Oxide Fuel

Evaluated Nuclear Data Files/B-version 5

End of Cycle

Flux Trap

Fiscal Year

Generic Environmental Statement for Use of Mixed-Oxide Fuel

Hazardous Materials Regulations

Idaho National Engineering Laboratory

Infinite Core Multiplication Factor

Los Alamos National Laboratory.

Laboratory Directed Research and Development

Low-Enriched Uranium

Lawrence Livermore National Laboratory

Lockheed Martin Idaho Technologies Company

Lead Test Assembly

Light Water Reactor 
MCNP

MOX

MTHM

Mwd

NAS

NE

NRC

NW

ORIGEN2

ORNL

PCS

PIE

PRPP

psig

$\mathrm{Pu}$

PWR

ROD

$R \& D$

SE

SW

TD

TRA

WGPu

$\mathrm{wt} \%$
Monte Carlo Neutron Photon Computer program

Mixed Oxide Fuel $\left(\mathrm{UO}_{2} / \mathrm{PuO}_{2}\right)$

Metric Tons of Heavy Metal

Megawatt-Days

National Academy of Sciences

Northeast

Nuclear Regulatory Commission

Northwest

Oak Ridge Isotope Generation and Depletion computer program

Oak Ridge National Laboratory

Primary Coolant System

Post-Irradiation Examination

Peak Relative Pin Power

pounds per square inch guage

Plutonium

Pressurized Water Reactor

Record of Decision

Research and Development

Southeast

Southwest

Theoretical Density

Test Reactor Area

Weapons-Grade Plutonium

weight percent 


\subsection{INTRODUCTION}

In July 1995, a National Academy of Sciences (NAS) panel on the disposition of weapons plutonium (Pu or WGPU) recommended the simultaneous development of two conversion technologies for rendering weapons $\mathrm{Pu}$ unfit for use as nuclear weapons material: first, burn the $\mathrm{Pu}$ in civilian reactors; and second, vitrify the $\mathrm{Pu}$ with high level radioactive waste and bury it. ${ }^{5}$ The first option processes the material for use as mixed-oxide (MOX) reactor fuel to be burned in commercial light water reactors (LWRs). This option would derive useful energy from excess weapons plutonium while quickly bringing it to the spent fuel standard; the Department of Energy (DOE) defines the spent fuel standard as a concept in which the weapons-usable Pu is made as inaccessible for weapons use as the much larger and growing quantity of $\mathrm{Pu}$ that exists in spent nuclear fuel from commercial LWRs. ${ }^{6}$

The DOE has prepared a draft of the "Storage and Disposition of Weapons-Usable Fissile Materials Programmatic Environmental Impact Statement." term storage and disposition alternatives and provides the necessary background, data, and analyses to help decisionmakers and the public understand the potential environmental impacts of each alternative. The DOE has also published a "Technical Summary Report for Surplus WeaponsUsable Plutonium Disposition. ${ }^{7}$ Several excellent overviews ${ }^{8-12}$ on plutonium disposition and several more specific papers ${ }^{13-19}$ on MOX fabrication and utilization were also published in 1996. Useful references on plutonium disposition published before 1996 are listed in our previous work. $^{1-4}$

The first disposition option is of interest here: using plutonium in nuclear reactor fuel, so that the plutonium remaining at the end of the fuel cycle is an integral part of spent reactor fuel. Although this approach would not transform all the plutonium into fission products, the plutonium remaining in the spent fuel would be difficult to extract for the manufacture of fission weapons because of the intense radiation emitted by fission products contained in the spent fuel, and because the fraction of ${ }^{240} \mathrm{Pu}$ would increase during irradiation.

In the United States, ail the reactors suitable for this option are LWRs that burn uranium fuel in the form of uranium oxide $\left(\mathrm{UO}_{2}\right)$ ceramic pellets. For plutonium disposition, the $\mathrm{UO}_{2}$ would be mixed with plutonium oxide $\left(\mathrm{PuO}_{2}\right)$ to form "mixed-oxide" (MOX) fuel. Several tests of partial core loading of MOX fuel were conducted in U.S. LWRs during the 1960s and 1970s, using plutonium recovered from LWR fuel. 
The Academy presents a list of major unresolved issues that must be addressed before a program to dispose of weapons-grade plutonium in LWRs can begin in the U.S. ${ }^{5}$ Some of the key technical issues on this list will require a reactor testing program for resolution. Resolution of these issues can essentially be characterized as demonstrating, with sufficient assurance to gain public support and to obtain licensing from the Nuclear Regulatory Commission (NRC), that LWRs can be operated safely with MOX fuel. The application to license operation with MOX fuel must be amply supported by experimental data. Numerous tests must be performed to obtain these data.

A great deal of useful testing could be performed in a test reactor, such as the Advanced Test Reactor (ATR) located in Idaho. The DOE plans to irradiate MOX pellets in the ATR. ${ }^{8}$ These tests will verify performance and determine if there is any corrosive reaction between the cladding of the fuel and alloying agents (gallium) in the plutonium. Many of the specific issues that must be resolved before a commercial reactor can be licensed to operate with MOX fuel can be resolved by experiments in a test reactor much more quickly and economically than by testing in commercial reactors. Following irradiation of the fuel experiments, the fuel must be examined in a hot cell to fully characterize the behavior of the fuel and thus assess its acceptability for use in LWRs.

The Record of Decision (ROD) on the plutonium disposition options is scheduled for December 1996. Burning MOX fuel in existing LWRs is one of the options likely to be pursued. If this option is selected, MOX testing in the ATR is very likely. The NAS recommends that the ROD should actively support pursuing the current reactor/spent-fuel option and the vitrificationwith-wastes option. The NAS recommends that project-oriented activities be initiated on both options, in parallel, at once. ${ }^{5}$

The fabrication, irradiation, and examination of MOX fuel is the single most expensive item recently identified by Oak Ridge National Laboratory (ORNL) and Lawrence Livermore National Laboratory (LLNL) in the long range R\&D plan for reactor-based plutonium disposition technologies (ORNL/MD/LTR-12). The prototypic fuels testing program was conservatively estimated to cost $\$ 50 \mathrm{M}$ and to last 9 years. The plan also states that this $R \& D$ area is likely to be a critical path item.

All of the specific requirements for MOX fuel testing can be subsumed into one broad requirement: MOX fuel must be shown to function without compromising the safety of operation. To receive NRC licensing approval for use in a commercial reactor, MOX fuel rods must be shown capable of withstanding a specified level of burnup without losing structural integrity or releasing fission products through the cladding. This capability must be demonstrated by a test irradiation 
program. After irradiation, fuel samples will be subjected to various kinds of physical examination, including visual inspection, ceramograpy, electron microscopy, and chemical analysis. Before a commercial reactor can be licensed to operate with a partial core loading of MOX fuel, the compatibility of MOX fuel assemblies and urania fuel assemblies must be demonstrated.

Partial core loadings of MOX fuel are in use in Europe. ${ }^{13,16}$ That experience, however, is not directly transferable. Significant differences exist between European MOX in current use, MOX studied in former U.S. investigations summarized in the GESMO (Generic Environmental Statement for the Use of Mixed-Oxide Fuel) Report in 1976, and the present MOX to be manufactured in the U.S. from excess weapons Pu. First, European MOX employs reactor-grade $\mathrm{Pu}$, which is less rich in the fissile ${ }^{239} \mathrm{Pu}$ isotope. Reactor-grade Pu contains a higher ratio of ${ }^{240} \mathrm{Pu}$ to ${ }^{239} \mathrm{Pu}$ than weapons-grade $\mathrm{Pu}$. ${ }^{240} \mathrm{Pu}$ has an almost zero thermal fission cross section, but a relatively high capture cross section. From a neutronics viewpoint, weapons-grade $\mathrm{Pu}$ is significantly more reactive than reactor-grade Pu. Second, European MOX uses plutonium dioxide contents up to $4 \%$ by weight, whereas $7 \%$ plutonium dioxide is proposed by the U.S. reactor vendors for weapons Pu disposition. This increase in Pu content affects the fuel's material properties and behavior, as well as its response in reactor transients. Finally, the relatively higher thermal fission cross sections of ${ }^{239} \mathrm{Pu}$ and ${ }^{241} \mathrm{Pu}$, combined with their higher release of neutrons upon fission, requires that a depletable neutron absorber be incorporated into MOX fuel fabricated from weapons Pu. U.S. vendors have recommended gadolinium or erbium additions. European MOX does not require or employ depletable neutron absorbers. Furthermore, oxide fuel performance is known to be very sensitive to fabrication variables such as fuel homogeneity, porosity, density, stability, stoichiometry, sintering temperatures and schedules, grain size, and others. These fabrication variables must be defined for our process relative to acceptable in-reactor performance. Therefore, MOX fuel manufactured in the U.S. from weapons-grade Pu cannot be shown to perform acceptably solely on the basis of European experience.

Westinghouse, General Electric, and ABB-Combustion Engineering recognize that experimental irradiations of special MOX fuel assemblies, called "Lead Test Assemblies" (LTAs), must take place in commercial reactors of a given type before such reactors can be licensed to use MOX fuel in a significant portion of their cores. Even for an LTA irradiation program, the safeguards concern of using weapons-grade plutonium in commercial reactors must be addressed. Furthermore, utilities may not accept the liabilities associated with an LTA program.

However, even before irradiation of LTAs in commercial reactors, a great deal of useful testing could be performed in a test reactor such as the ATR. Furthermore, some issues cannot be 
resolved with LTAs and must be addressed by specially-designed experiments in a test reactor. MOX fuel experiments in a test reactor comprise the first required phase in a MOX fuel qualification program. 


\subsection{FUEL TESTING IN THE ADVANCED TEST REACTOR}

The most suitable, indeed ideal, test reactor for performing these MOX fuel irradiations is the Advanced Test Reactor (ATR) located on the Idaho National Engineering Laboratory (INEL) and operated by Lockheed Martin Idaho Technologies Company (LMITCO). The ATR has large test spaces in and around the core, a high neutron flux, a wide latitude of experiment parameter control, extensive instrumentation facilities, and a regular operating schedule. The ATR is a 250 MW (thermal) LWR that was designed specifically for LWR fuels testing, and it has performed this mission for over 25 years. The ATR has the capability to perform the irradiation experiments required to address almost all of the technical issues that must be addressed in a MOX fuel testing program. The ATR can inexpensively and quickly perform capsule irradiations that could be used to resolve many important issues, such as fabrication process refinement, in a timely way prior to more sophisticated integral testing. Ultimately, the ATR's test loops could be used to accommodate a $5 \times 5$ pressurized water reactor (PWR) mini-assembly, or a $4 \times 4$ boiling water reactor ((BWR) mini-assembly, having prototypic MOX fuel rod diameters and pitches, but with fewer rods. The fact that the ATR has a high neutron flux allows for accelerated testing relative to LTAs. Furthermore, the ATR's short cycle length (usually about 40 days) allows for ease of access to experiments for the required interim examinations. Commercial reactors simply cannot be shut down for the removal of LTAs at other than scheduled refueling outages, which typically occur once each 12 to 24 months.

Located within the ATR core-reflector tank are 62 irradiation test "holes" and nine flux traps. Except for the five flux traps containing flow loops, which have their own separate cooling systems, these cylindrical cavities, extending the full length of the core, are cooled by water from the primary cooling system (PCS). Test specimens irradiated in the test holes are usually contained in sealed capsules, although bare specimens are sometimes inserted into the holes. Figure 1 illustrates the locations of the various types of test holes. Figure 2 shows a typical drop-in capsule in the ATR.

The initial phase of the MOX qualification testing will be a series of single rod or capsule tests conducted in "B" and/or "I" holes of the ATR. Irradiation charges for the "B" hole positions are reasonably low, while irradiation charges for the "I" hole positions are very low and may be 


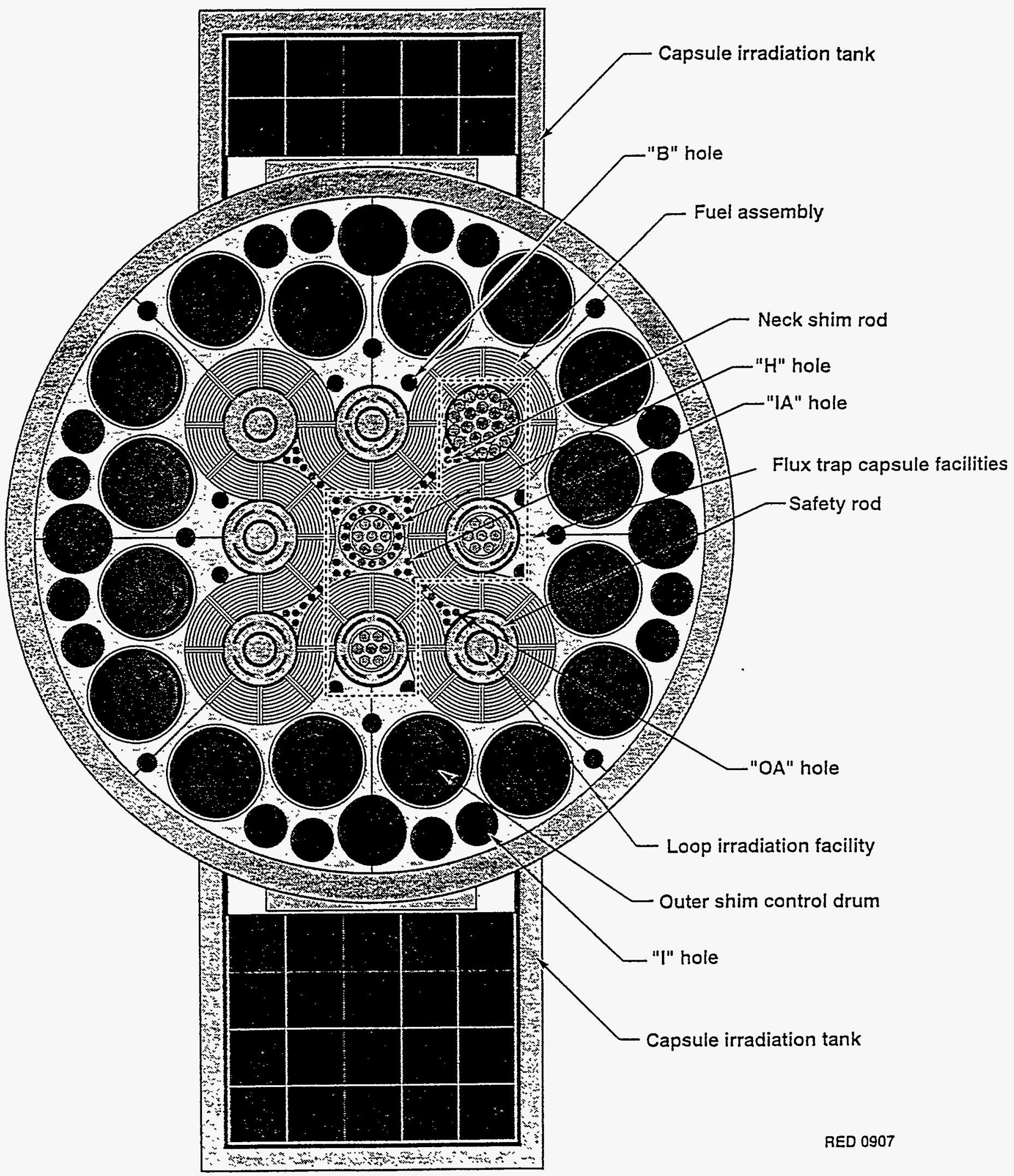

Figure 1. Cross-sectional diagram of the Advanced Test Reactor 


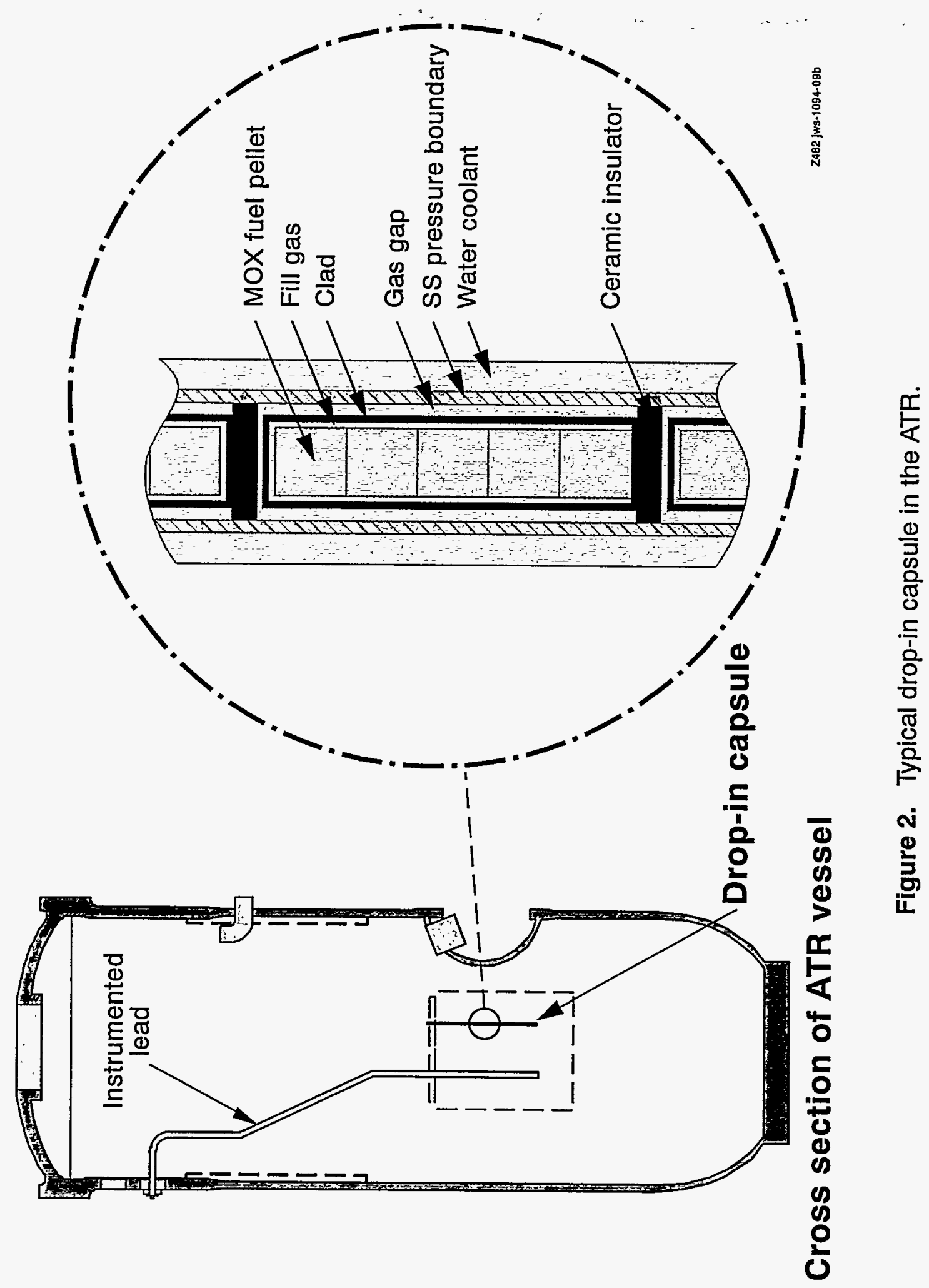


waived. The design and fabrication of the capsules are also simple and inexpensive. Thus, capsule irradiations provide a relatively inexpensive route to obtain useful preliminary data quickly. Oxide fuel performance is known to be sensitive to the pellet fabrication process. Capsule tests conducted at near prototypic fuel centerline temperatures followed by postirradiation examinations will provide critical feedback to the pellet fabricators, allowing for process refinement. Initial data on the behavior of gallium and/or americium in the fuel, on the behavior of depletable neutron absorbers, and on fission gas release may be obtained in the capsule irradiation phase.

Before a test can be installed in the ATR, it must be shown to be compatible with the design and operational constraints on the reactor. The test hardware must fit geometrically into a test space that can provide the required neutron flux. The materials used in the test must be compatible with the reactor materials. The thermohydraulic environment in the test locations must be suitable for successful completion of the test. The scheduling requirements for the test must fit with the scheduling commitments that have been made for the reactor to conduct other test programs. Most important of all, the test hardware and the test program must not compromise the operational safety of the reactor.

Drop-in capsules without instrumented leads can be designed to hold plutonium-based pellets for placement in ATR irradiation positions. This type of test space is cooled by primary cooling-system water that is separated from the core coolant in the core inlet plenum and rejoined with the core coolant in the core outlet plenum.

Some analyses have been performed on a variety of drop-in capsules to resolve fundamental questions about the suitability of the ATR for a MOX fuel testing program. The test results from a MOX fuel testing program must give valid data from which to draw conclusions about MOX fuel performance in a commercial reactor. Also, the presence of MOX fuel test specimens in the ATR must not impair the ability of the reactor to perform simultaneous irradiations in other test locations, because only a relative few of the ATR's test locations would be occupied by MOX fuel specimens.

The analyses included calculations of neutron fluxes and spectra, fuel burnup rates, heating rates, temperatures, and decay activities. Similar analyses using similar methods were performed for typical commercial reactors: a Pressurized Water Reactor, a Boiling Water Reactor, and a CANDU (heavy water) reactor. We compared the conditions in commercial reactors containing MOX fuel with the conditions available at various positions in the ATR. We are able to select certain ATR positions that achieve reasonable matches to typical commercial reactor conditions. 


\subsection{OBJECTIVES OF TESTS}

The program for testing MOX fuel in the ATR will be formulated to demonstrate that MOX fuel can be safely used in commercial nuclear power reactors. ${ }^{8}$ Therefore, when practical, the configuration of the test specimens and the thermal conditions in which they will operate will be set to resemble those in the commercial reactors in which MOX fuel will be burned. The physical configuration of the test fuel specimens includes parameters such as composition, density, dimensions, and cladding design. The thermal conditions include parameters such as linear heat generation rate, pellet surface temperature, and pellet centerline temperature.

The key issue in evaluating the suitability of MOX fuel pellets for use in commercial nuclear power reactors is whether they give satisfactory performance over the required service life of the fuel; this service life is measured in terms of burnup, in units of MWd/MTHM (megawattdays per metric ton of heavy metal). Post-irradiation examination (PIE) of the fuel pellets will reveal whether the pellets performed in a satisfactory manner during their irradiation.

Table 1 below gives the "prototypic" conditions for fuel in a typical commercial power reactor. In addition to the assessment of MOX in the configuration and under the conditions given in this table, the test program will allow comparisons to be made of the performance of MOX fuel made from weapons-grade plutonium (WGPu) treated to remove gallium and not so treated, and also of the performance of MOX fuel made by different conversion methods. Table 2 shows a possible test matrix that would permit these comparisons to be made.

Table 1. Prototypic condition expected in WG-MOX fuel rods in a commercial PWR

\begin{tabular}{|l|l|l|}
\hline \multicolumn{1}{|c|}{ Parameter } & \multicolumn{1}{c|}{ Average Rod } & \multicolumn{1}{c|}{ Peak Rod } \\
\hline Pellet diameter [in, cm] & $0.3225,0.82$ & $0.3225,0.82$ \\
\hline Pellet height [in, cm] & $0.530,1.35$ & $0.530,1.35$ \\
\hline Sintered density [\% TD] & 95.6 & 95.6 \\
\hline Pu content (\% total, \% fissile) & $4.9,4.6$ & $4.9,4.6$ \\
\hline Cladding OD [in, cm] & $0.374,0.95$ & $0.374,0.95$ \\
\hline Cladding thickness [in, cm] & $0.045,0.11$ & $0.045,0.11$ \\
\hline Linear heat generation rate [kW/ft] & 5.68 & 14.2 \\
\hline Flux (fast/thermal) [n/(cm ${ }^{2}$-s)] & $3.4 E 14 / 0.185 E 14$ (ratio $=18.7$ ) & $?$ \\
\hline Pellet surface temperature [C, F] & 400,750 & $?$ \\
\hline Pellet centerline temperature [C, F] & 930,1700 & $?$ \\
\hline Burnup [GWd/MT] & 44 & 60 \\
\hline
\end{tabular}


Table 2. Proposed Test Matrix (about 24 pellets of each, each type individually sealed in $\mathrm{Zr}$ clad)

\begin{tabular}{|c|c|c|c|c|c|}
\hline Fuel & Description & Feed & $\begin{array}{c}\text { Ga } \\
\text { Treatment }\end{array}$ & $\begin{array}{c}\text { Heat Rate } \\
{[\mathrm{kW} / \mathrm{ft}]}\end{array}$ & $\begin{array}{c}\text { Burnup } \\
\text { GWd/MT }\end{array}$ \\
\hline Control A & LEU & LEU & $\mathrm{n} / \mathrm{a}$ & 6 & 15 \\
\hline Control B & LEU & LEU & $\mathrm{n} / \mathrm{a}$ & $6-10$ & 30 \\
\hline Test 1A & $5 \%$ Pu MOX & Ga-free WG Pu & $\mathrm{n} / \mathrm{a}$ & 6 & 15 \\
\hline Test 1B & $5 \%$ Pu MOX & Ga-free WG Pu & $\mathrm{n} / \mathrm{a}$ & $6-10$ & 30 \\
\hline Test 2A & $5 \%$ Pu MOX & $1 \%$ Ga WG Pu & none & 6 & 15 \\
\hline Test 2B & $5 \%$ Pu MOX & $1 \%$ Ga WG Pu & none & $6-10$ & 30 \\
\hline Test 3A & $5 \%$ Pu MOX & $1 \%$ Ga WG Pu & thermal & 6 & 15 \\
\hline Test 3B & $5 \%$ Pu MOX & $1 \%$ Ga WG Pu & thermal & $6-10$ & 30 \\
\hline
\end{tabular}

In the ATR, the potential exists to irradiate test specimens under a higher neutron flux than the prototypic value in a commercial reactor. This option would allow the desired burnup to be achieved more rapidly, and it may or may not lead to better approximation to the commercial reactor operating conditions. On one hand, higher fluxes would produce higher temperatures, tending to produce test conditions that may not be as close to the commercial reactor fuel environment as the conditions that would arise from irradiation at the flux found in the commercial reactor. On the other hand, however, the shorter fuel pin length of the ATR test specimens and the much lower coolant inlet temperature in the ATR as compared to commercial reactors would tend to reduce pin temperatures. So irradiation at higher fluxes has competing consequences. Also, in order to obtain quick results for judging whether any gross deficiencies in fuel performance might occur, test managers may elect to irradiate some test specimens to lower burnup values than the prototypic ones. Conclusions and decisions regarding such tradeoffs have not been made yet.

\section{MOX and EMOX Fuel}

Two types of fuel containing WGPU have been evaluated in this LDRD project: standard MOX fuel and "evolutionary" MOX fuel, or EMOX fuel. In standard MOX fuel, henceforth denoted simply as $\mathrm{MOX}$ fuel, $\mathrm{WGPuO}_{2}$ comprises roughly 3-7 wt\% of the mixture, and the rest is natural or depleted $\mathrm{UO}_{2}$. It has been proposed ${ }^{20-23}$ that a WGPu-disposal program should use fuel that contains no uranium at all, so that no new plutonium is bred as the WGPU is depleted. This "non-fertile fuel," which would comprise about $20 \mathrm{wt} \% \mathrm{WGPuO}_{2}$ and about $80 \mathrm{wt} \%$ nonfissionable filler, would be a radical departure from any fuel composition previously used in commercial reactors. Thus, it could be desirable to evaluate an intermediate fuel form, comprising about $11 \mathrm{wt} \% \mathrm{WGPuO}_{2} 84 \%$ natural or depleted $\mathrm{UO}_{2}$, and the rest as filler such as $\mathrm{ZrO}_{2}$ and/or 
$\mathrm{CaO}$. This intermediate form is EMOX, which is being investigated and fabricated at the Los Alamos National Laboratory (LANL).

Because it may be possible to obtain EMOX fuel pellets more quickly than MOX pellets, some investigations discussed below, especially the mechanical design issues, were focused primarily on the EMOX fuel form. However, the main thrust of a WGPu-disposal testing program in the ATR is likely to be the MOX fuel form; therefore, most of the work done for this LDRD project considered MOX fuel. 


\subsection{MECHANICAL DESIGN OF DROP-IN CAPSULES}

Five different locations in the ATR were considered for MOX fuel test sites in this LDRD: small, medium, and large I-holes and small and large B-holes (Figure 1 shows the layout of the ATR and identifies the test locations; Table 3 gives the dimensions and other features of each of the test locations considered). When a test specimen is placed in a test location, it is contained in an assembly called a drop-in capsule, and one or more capsules are placed in a holder called a basket.

Table 3. ATR Experiment and Isotope Production Unperturbed* Fluxes at $250 \mathrm{MW}$

\begin{tabular}{|c|c|c|c|c|}
\hline Number & Diameter $(\mathrm{cm})$ & Name & $\begin{array}{c}\text { Thermal Flux } \\
\left(10^{14} \mathrm{~cm}^{-2} \mathrm{~s}^{-1}\right) \\
(2200 \mathrm{~m} / \mathrm{s})\end{array}$ & $\begin{array}{c}\text { Fast Flux } \\
\left(10^{14} \mathrm{~cm}^{-2} \mathrm{~s}^{-1}\right) \\
(>1 \mathrm{MeV})\end{array}$ \\
\hline 8 & 2.22 & B & 5.75 & 1.85 \\
\hline 4 & 3.81 & B & 2.48 & 0.37 \\
\hline 14 & 1.59 & H & 4.28 & 3.83 \\
\hline 8 & 1.59 & A & 4.82 & 3.83 \\
\hline 4 & 1.59 & A & 4.64 & 5.25 \\
\hline 4 & 12.70 & I & 0.39 & 0.03 \\
\hline 16 & 8.26 & I & 0.77 & 0.03 \\
\hline 4 & 3.81 & I & 1.89 & 0.07 \\
\hline 4 & 6.05 & FT & 8.80 & 1.90 \\
\hline 1 & 10.16 & FT & 8.80 & 1.90 \\
\hline 1 & 13.65 & FT & 8.80 & 1.90 \\
\hline 3 & 5.40 & FT & 8.80 & 1.90 \\
\hline
\end{tabular}

* Self-shielding and other effects from particular test materials can alter flux values considerably.

EMOX fuel pellets may be obtainable in small quantities on fairly short notice from LANL. Figure 3 shows a capsule design for the LANL EMOX pellets, with the pellets also illustrated.

Two key issues confronting capsule designers are internal and external pressure on the cladding. The operating pressure of ATR is $355 \mathrm{psig}$, whereas commercial reactors operate at 
pressures up to about $2250 \mathrm{psig}$. In order for commercial reactor operating conditions to be represented accurately, the test fuel cladding would ideally be subjected to external pressures comparable to commercial reactor operating pressures. However, in order for such pressures to be imposed on the cladding exterior, the cladding would have to be enclosed within a thick-walled tube containing an appropriate gas mixture, or perhaps pressurized water, in the interstitial space. This double-encapsulation concept is illustrated in Figures 2 and 4. Because of the thickness of the region between the fuel and the coolant water, such an arrangement would provide very poor heat transfer, and the allowable neutron flux level would have to be substantially reduced in order to keep temperatures within acceptable limits. Thus, the time required to achieve prescribed burnup levels would increase.

Also, according to ATR Technical Specifications, ${ }^{24}$ "Experiment containment that holds pressure greater than $235 \mathrm{psig}$, or contains material that can generate pressure pulses greater than 430 psig, shall have a design that meets the intent of ASME Section III, Class I standards, ${ }^{25}$ or the ability, demonstrated by prototype testing or other means, to withstand service conditions without failure." It is not known whether the fission product gas pressure generated within the cladding will be less than 235 psig at high values of burnup. Therefore, it is assumed that the cladding design will have to meet the stipulations of this ATR Technical Specification. Zircaloy, the standard material for cladding in commercial light water reactors, is not qualified as a pressure vessel material under ASME Section III, Class 1. Therefore, the design shown in Figure 3 specifies stainless steel as a cladding material.

One approach that could allow very high external pressures to be imposed on the cladding without requiring the cladding to be qualified under ASME Section III, Class 1 is to place the test specimens in an ATR test loop, which has its own cooling system separate from the main cooling system of the reactor. However, this approach would be more expensive. The capabilities of the ATR loops for MOX testing were discussed at length in the FY 1995 report for this LDRD project. $^{3}$

For the EMOX testing program, the possibility of beginning irradiations in the very near future led us to specify an existing basket design. Figure 5 shows a three-hole basket that can accommodate the EMOX capsule shown in Figure 3.

No mechanical design has been completed for MOX fuel capsules. However, the same issues on cladding external and internal pressure apply to MOX fuel as to EMOX fuel. Therefore, the cladding for the MOX fuel tests may also be stainless steel. However, utilities may insist on 


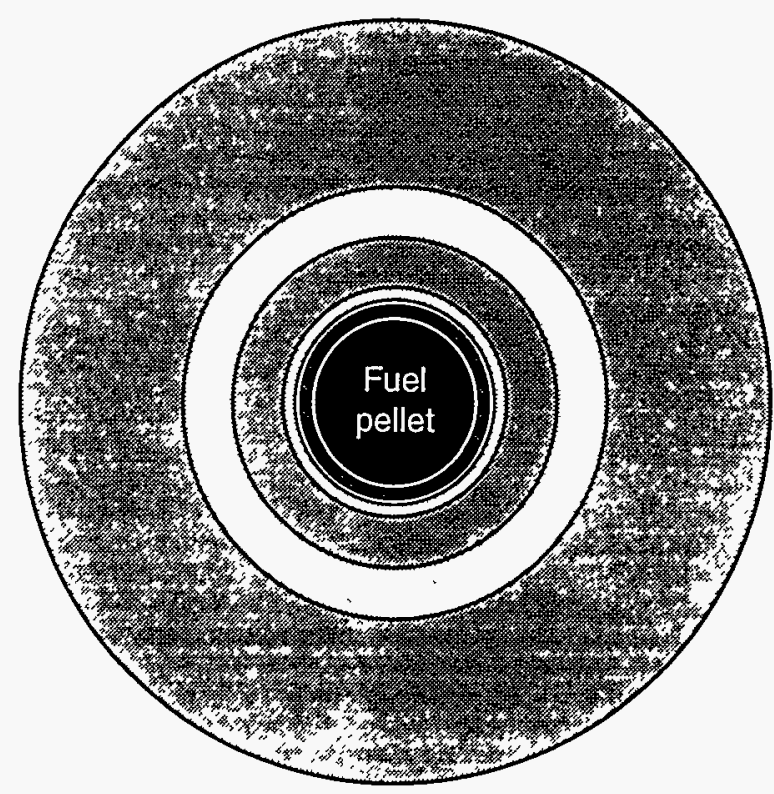

\section{Double Encapsulation}

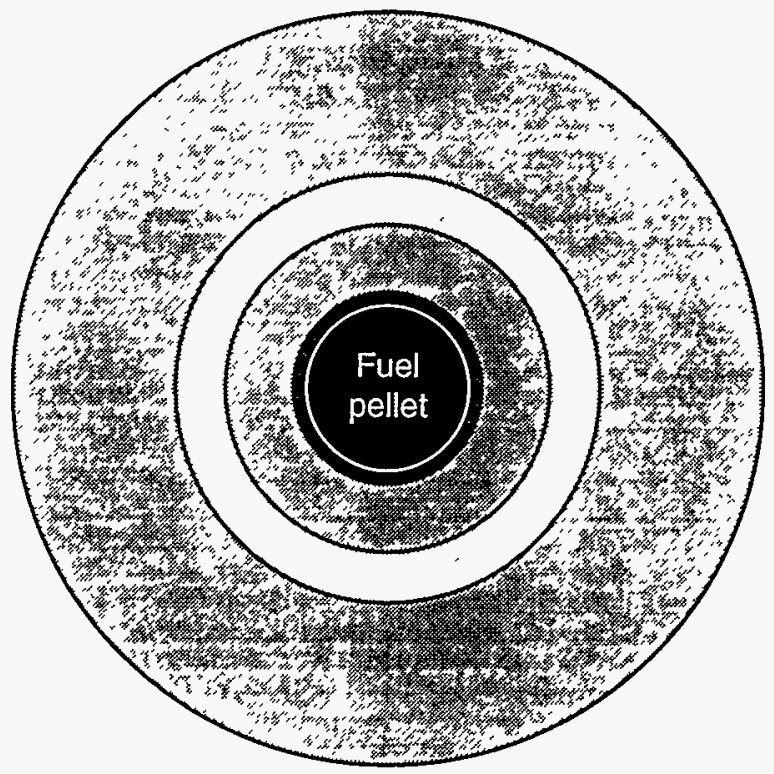

\section{Single Encapsulation}

\section{Water}

SST tube

Zircaloy cladding

C283-WHT-996-19t

Figure 4. Radial schematic view of MOX test assembly. 


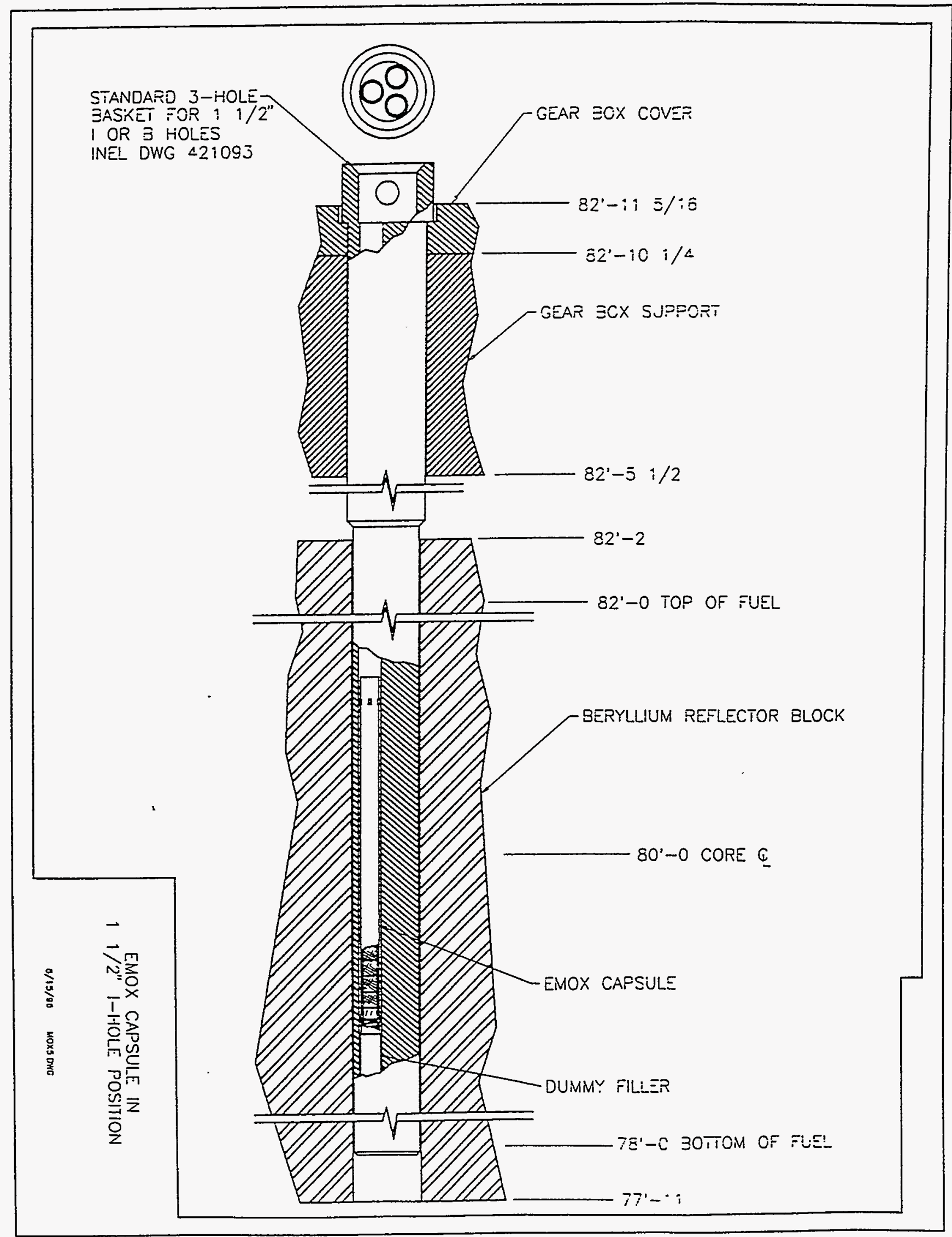

Figure 5. A three-hole basket that contains one EMOX capsule in a small I-hole in ATR. 
data from tests with the same Zircaloy cladding that will almost certainly be used on MOX fuel in commercial reactors. Double-encapsulation similar to that shown in Figure 4 may be required for the use of Zircaloy as the fuel cladding. The issue of cladding selection for ATR MOX fuel testing has not been resolved.

By the time MOX fuel testing is begun, the available pellet fabrication process will be better developed, and pellets equal in size to commercial $\mathrm{UO}_{2}$ pellets will be available. Thus, the pellet dimensions will be essentially the same as the prototypic dimensions given in Table 1. As discussed below, the MOX testing program may pack several MOX fuel rods into a single test space, especially if a large test space such as a large I-hole is chosen. To hold multiple fuel rods, special baskets will need to be fabricated. 


\subsection{NEUTRONICS AND THERMOHYDRAULICS STUDIES OF DROP-IN CAPSULES}

Neutronics studies performed for this LDRD project to support MOX fuel testing in the ATR dealt with five specific parameters: heat rates, burnup, fast neutron fluxes, residual radioactivity, and residual decay heat loads. These parameters were evaluated for several configurations of MOX fuel composition, fuel pin arrangement, and location in the ATR. Some thermohydraulics calculations were also performed, as discussed below. Other neutronics calculations, discussed in Section 6.0 below, dealt with MOX fuel in commercial reactors.

The neutronics calculations were performed with the widely-used MCNP Monte Carlo computer code ${ }^{26}$ and a standard MCNP input model of the ATR. ${ }^{27}$ Figure 4 shows the radial configuration of a MOX fuel drop-in capsule. Table 4 shows the dimensions of the components illustrated in the figure. Table 5 gives the isotopic compositions of $\mathrm{MOX}, \mathrm{UO}_{2}$, and $\mathrm{EMOX}$ fuel pellets.

Table 4. Drop-in capsule component dimensions for MOX fuel testing in ATR used in neutronics analysis

\begin{tabular}{|c|c|c|c|}
\hline Component & $\begin{array}{c}\text { Region thickness } \\
\text { (inches) }\end{array}$ & $\begin{array}{c}\text { Outer diameter } \\
\text { (inches) }\end{array}$ & Outer radius (cm) \\
\hline MOX fuel pellet & $3.255 \mathrm{e}-01$ & $3.255 \mathrm{e}-01$ & $4.134 \mathrm{e}-01$ \\
\hline Gas gap & $3.244 \mathrm{e}-03$ & $3.320 \mathrm{e}-01$ & $4.216 \mathrm{e}-01$ \\
\hline Cladding & $2.500 \mathrm{e}-02$ & $3.820 \mathrm{e}-01$ & $4.85 \mathrm{e}-01$ \\
\hline Gap & $2.500 \mathrm{e}-03$ & $3.870 \mathrm{e}-01$ & $4.915 \mathrm{e}-01$ \\
\hline Inner SST tube & $4.000 \mathrm{e}-02$ & $4.670 \mathrm{e}-01$ & $5.931 \mathrm{e}-01$ \\
\hline Water annulus & $9.109 \mathrm{e}-02$ & $6.492 \mathrm{e}-01$ & $8.245 \mathrm{e}-01$ \\
\hline SST tube & $9.843 \mathrm{e}-02$ & $8.460 \mathrm{e}-01$ & $1.074 \mathrm{e}+00$ \\
\hline Outer water annulus & $3.270 \mathrm{e}-01$ & $1.500 \mathrm{e}+00$ & $1.905 \mathrm{e}+00$ \\
\hline
\end{tabular}


Table 5. Composition of $\mathrm{MOX}^{\mathrm{a}}, \mathrm{UO}_{2}{ }^{\mathrm{b}}$ and Non-fertile ${ }^{\mathrm{c}}$ fuel pellets used in PWR capsule neutronics calculations

\begin{tabular}{|c|c|c|c|}
\hline Material & $\begin{array}{c}\text { MOX composition } \\
\text { (atoms/b-cm) }\end{array}$ & $\begin{array}{c}\mathrm{UO}_{2} \text { composition } \\
\text { (atoms/b-cm) }\end{array}$ & $\begin{array}{c}\text { EMOX composition } \\
\text { (atoms/b-cm) }\end{array}$ \\
\hline $\mathrm{Pu}-239$ & $1.0847 \mathrm{e}-03$ & & $2.2482 \mathrm{e}-03$ \\
\hline $\mathrm{Pu}-240$ & $6.8372 \mathrm{e}-05$ & & $1.4171 \mathrm{e}-04$ \\
\hline $\mathrm{Pu}-241$ & $4.6354 \mathrm{e}-06$ & & $9.6078 \mathrm{e}-06$ \\
\hline $\mathrm{Pu}-242$ & $1.1588 \mathrm{e}-06$ & & $2.4019 \mathrm{e}-06$ \\
\hline $\mathrm{U}-235$ & $1.5639 \mathrm{e}-04$ & $1.1733 \mathrm{e}-03$ & $1.3132 \mathrm{e}-04$ \\
\hline $\mathrm{Ca}$ & $2.2186 \mathrm{e}-02$ & & $4.3179 \mathrm{e}-04$ \\
\hline $\mathrm{U}-238$ & & $2.2293 \mathrm{e}-02$ & $1.8629 \mathrm{e}-02$ \\
\hline $\mathrm{Zr}$ & $4.7001 \mathrm{e}-02$ & & $2.303 \mathrm{e}-03$ \\
\hline $\mathrm{O}_{2}$ & $1.0540 \mathrm{e}+01$ & $4.6933 \mathrm{e}-02$ & $4.8226 \mathrm{e}-02$ \\
\hline \hline
\end{tabular}

a Weapons-grade $\mathrm{PuO}_{2}\left(5 \mathrm{wt} \%\right.$ ), natural $\mathrm{UO}_{2}$ (95 wt\%).

b $\mathrm{UO}_{2}$ with U-235 enrichment $5 \%$.

c Weapons-grade $\mathrm{PuO}_{2}(10.9 \mathrm{wt} \%)$, natural $\mathrm{UO}_{2}$ (83.9 wt\%), $\mathrm{ZrO}_{2}(4.7 \mathrm{wt} \%)$, and $\mathrm{CaO}(0-5$ wt\%).

Linear heat rate, or heat generated per unit length of a fuel pin, is the key parameter that determines the temperatures in a fuel pin of a specific design in a specific thermohydraulic regime. This parameter is a meaningful indicator of how a fuel pin would behave thermally if put into different reactors. Also, it was used as input to the thermal calculations performed for this LDRD. Except where specifically noted otherwise, the MOX drop-in capsules contain 100 pellets, occupying $30.0 \mathrm{in}$. out of a total capsule length of $4 \mathrm{ft}$. Therefore, direct comparisons can also be made if total heat rate is given instead of linear heat rate, and computational results are sometimes presented as total heat rates.

As discussed above, the basic goal of the whole ATR irradiation program is to achieve specified levels of burnup in the fuel specimens placed in the ATR. Clearly, the relationship between burnup level achieved and the residence time of fuel in the reactor is a crucial parameter to be calculated.

The fast neutron fluxes in the test specimens are the primary cause of atomic displacements in the fuel microstructure. Calculated values can be used to predict the level of fuel damage to be expected in the tests, and they can be correlated after the tests with the actual damage observed.

The residual radioactivity and the residual decay heat loads emitted by the test fuel after it is removed from the ATR must be known to determine how long to let the fuel cool before shipping, and how to handle the fuel for shipping and PIE. 
The neutronics calculations discussed in this section may be divided for discussion into three groups. In each group, results were obtained for MOX fuel compositions containing 3.0, 5.0 , and $7.0 \mathrm{wt} \% \mathrm{WGPuO}_{2}$. In the first group, the primary issue was how best to arrange fuel rods in large, medium, and small ATR I-holes. In particular, in a large 1-hole, which has room to hold several fuel rods at once, what penalties does self-shielding impose on the performance of each fuel rod? How much longer would it take to achieve the desired burnup level if several rods were placed in the I-hole than if only one were inserted?

In the second group of calculations, the primary issue was how a single fuel pin would perform in the different available test locations in the ATR: small, medium, and large I-holes and small and large B-holes. Thermohydraulics analyses were performed using the results from this group of neutronics calculations as input. These thermohydraulics analyses gave the maximum expected fuel temperatures in the MOX capsules.

The third group of calculations addressed the behavior of EMOX fuel.

In all of the calculations reported in this section, the fuel pellets were assumed to be contained in a single layer of cladding made of stainless steel. It is not unlikely that utility requirements will lead to the use of Zircaloy cladding, with possible double-encapsulation in stainless steel, in the actual test program.

\subsection{MOX Fuel in Large I-Holes}

In these calculations, an ATR configuration was assumed in which the power distribution among the NW, NE, Center, SW, and SE lobes was 17, 30, 25.9, 26, and $27 \mathrm{MW}$, respectively, for a total thermal power of $125.9 \mathrm{MW}$. Burnup rates were calculated at the beginning of the first cycle, and burnup quantities at the ends of various time periods were assumed to be accumulated at those rates, without accounting for depletion. The ATR was assumed to operate at constant power for seven 42-day cycles per year.

For a $\mathrm{WGPuO}_{2}$ concentration of $3.0 \mathrm{wt} \%$, Table 6 compares the total heat rates generated in each fuel pin in two possible arrangements in a large I-hole in the East quadrant of the ATR. Figure 6 shows these two arrangements: in one, a single MOX fuel pin is located in the center of the I-hole, and in the other, six pins are spaced evenly on a circle around the center of the I-hole. 
Table 6. Total heat rates of weapons-grade $\mathrm{MOX}$ fuel $\left(\mathrm{WGPuO}_{2} 3.0 \mathrm{wt} \%\right)$ capsules in a large Ihole in the East quadrant of ATR

\begin{tabular}{|c|c|c|c|c|c|c|c|c|}
\hline & $\begin{array}{c}\text { One } \\
\text { capsule }\end{array}$ & \multicolumn{7}{|c|}{ Six capsules in large I-hole ${ }^{\mathrm{A}}$} \\
\hline & Center & Average & 1 & 2 & 3 & 4 & 5 & 6 \\
\hline $\begin{array}{c}\text { Top 1 fuel } \\
\text { section }\end{array}$ & $5.278 \mathrm{e}-01$ & $3.630 \mathrm{e}-01$ & $2.747 \mathrm{e}-01$ & $3.649 \mathrm{e}-01$ & $4.189 \mathrm{e}-01$ & $3.320 \mathrm{e}-01$ & $4.146 \mathrm{e}-01$ & $3.731 \mathrm{e}-01$ \\
\hline 2 & $6.217 \mathrm{e}-01$ & $4.301 \mathrm{e}-01$ & $3.271 \mathrm{e}-01$ & $4.581 \mathrm{e}-01$ & $4.773 \mathrm{e}-01$ & $3.744 \mathrm{e}-01$ & $5.066 \mathrm{e}-01$ & $4.372 \mathrm{e}-01$ \\
\hline 3 & $5.876 \mathrm{e}-01$ & $4.204 \mathrm{e}-01$ & $3.256 \mathrm{e}-01$ & $4.379 \mathrm{e}-01$ & $4.925 \mathrm{e}-01$ & $3.794 \mathrm{e}-01$ & $4.798 \mathrm{e}-01$ & $4.073 \mathrm{e}-01$ \\
\hline $\begin{array}{c}\text { Bottom 4 } \\
\text { fuel section }\end{array}$ & $4.786 \mathrm{e}-01$ & $3.431 \mathrm{e}-01$ & $2.687 \mathrm{e}-01$ & $3.268 \mathrm{e}-01$ & $3.886 \mathrm{e}-01$ & $3.036 \mathrm{e}-01$ & $4.107 \mathrm{e}-01$ & $3.602 \mathrm{e}-01$ \\
\hline SST cladding & $2.020 \mathrm{e}-02$ & $1.948 \mathrm{e}-02$ & $1.325 \mathrm{e}-02$ & $1.667 \mathrm{e}-02$ & $2.278 \mathrm{e}-02$ & $2.463 \mathrm{e}-02$ & $2.331 \mathrm{e}-02$ & $1.623 \mathrm{e}-02$ \\
\hline SST tube & $2.029 \mathrm{e}-02$ & $1.983 \mathrm{e}-02$ & $1.313 \mathrm{e}-02$ & $1.711 \mathrm{e}-02$ & $2.328 \mathrm{e}-02$ & $2.523 \mathrm{e}-02$ & $2.351 \mathrm{e}-02$ & $1.670 \mathrm{e}-02$ \\
\hline $\begin{array}{c}\text { Water } \\
\text { annulus }\end{array}$ & $2.681 \mathrm{e}-02$ & $2.963 \mathrm{e}-02$ & $2.044 \mathrm{e}-02$ & $2.553 \mathrm{e}-02$ & $3.470 \mathrm{e}-02$ & $3.757 \mathrm{e}-02$ & $3.452 \mathrm{e}-02$ & $2.502 \mathrm{e}-02$ \\
\hline Outer SST & $2.141 \mathrm{e}-02$ & $2.087 \mathrm{e}-02$ & $1.389 \mathrm{e}-02$ & $1.773 \mathrm{e}-02$ & $2.464 \mathrm{e}-02$ & $2.661 \mathrm{e}-02$ & $2.482 \mathrm{e}-02$ & $1.755 \mathrm{e}-02$ \\
\hline Outer water & $2.935 \mathrm{e}-02$ & $3.216 \mathrm{e}-02$ & $2.166 \mathrm{e}-02$ & $2.667 \mathrm{e}-02$ & $3.787 \mathrm{e}-02$ & $4.232 \mathrm{e}-02$ & $3.795 \mathrm{e}-02$ & $2.647 \mathrm{e}-02$ \\
\hline
\end{tabular}

A Heat rate unit $=$ watt/gram per quadrant $M W$.

For selected NE $30 \mathrm{MW}$ cycle, the power split over NW, NE, Center, SW and SE lobes is 17, 30, $25.9,26$, and $27 \mathrm{MW}$, respectively. North-West quadrant $=23.48 \mathrm{MW}$, North-East quadrant 36.48 , and East quadrant $=34.98 \mathrm{MW}$.

The table gives the heat rate values for each pin and also the average value for the six-pin arrangement. Self-shielding in the six-pin configuration leads to a reduction in the average heat rate of about $30 \%$ in the fuel compared to the single-pin case. Similarly, the burnup rates are reduced by self-shielding in the six-pin arrangement, as displayed in Table 7. Tables 8-11 show the same quantities for $\mathrm{WGPuO}_{2}$ concentrations of 5.0 and $7.0 \mathrm{wt} \%$, and Figures 7-9 graphically display some of the information in these tables, along with the values of the fast neutron flux. 


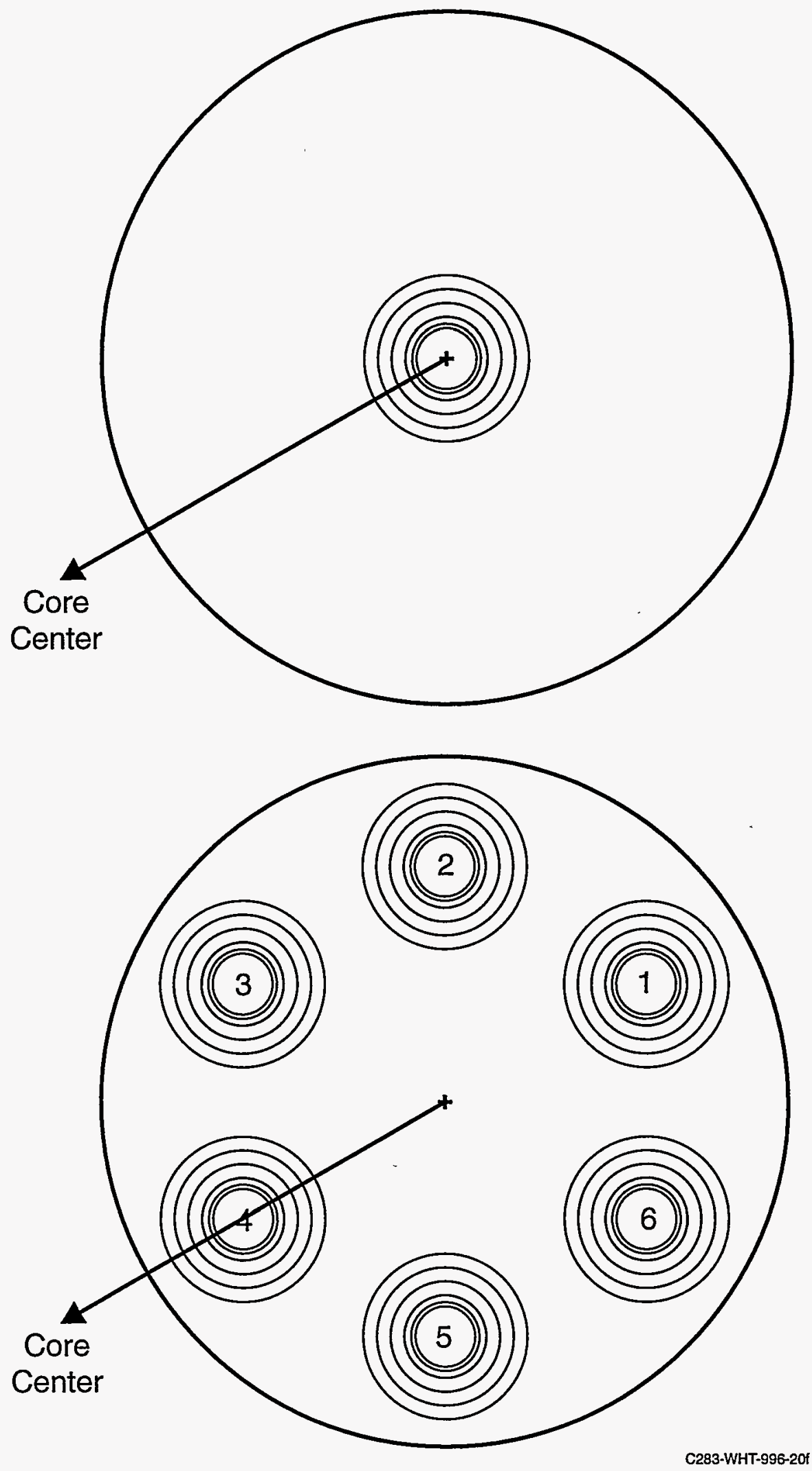

Figure 6. Plan view of ATR large I-hole with six capsules and with one capsule. 
Table 7. Burnup (MWd/MT) of weapons-grade $\mathrm{MOX}$ fuel $\left(\mathrm{WGPuO}_{2} 3.0 \mathrm{wt} \%\right)$ capsules in a large I-hole in the East quadrant of ATR

\begin{tabular}{|c|c|c|c|}
\hline Location & $\begin{array}{c}\text { Burnup (MWd/MT) } \\
\text { per irradiation cycle }\end{array}$ & $\begin{array}{c}\text { Burnup (MWd/MT) } \\
\text { per year }\end{array}$ & $\begin{array}{c}\text { Burnup (MWd/MT) } \\
\text { per 18 months }\end{array}$ \\
\hline $\begin{array}{c}\text { Single capsule in large } \\
\text { I-hole }\end{array}$ & $9.002 \mathrm{e}+02$ & $6.302 \mathrm{e}+03$ & $9.452 \mathrm{e}+03$ \\
\hline $\begin{array}{c}\text { Average of six } \\
\text { capsules }\end{array}$ & $6.211 \mathrm{e}+02$ & $4.347 \mathrm{e}+03$ & $6.521 \mathrm{e}+03$ \\
\hline \hline Capsule 1 & $4.855 \mathrm{e}+02$ & $3.399 \mathrm{e}+03$ & $5.098 \mathrm{e}+03$ \\
\hline Capsule 2 & $6.413 \mathrm{e}+02$ & $4.489 \mathrm{e}+03$ & $6.734 \mathrm{e}+03$ \\
\hline Capsule 3 & $7.040 \mathrm{e}+02$ & $4.928 \mathrm{e}+03$ & $7.392 \mathrm{e}+03$ \\
\hline Capsule 4 & $5.341 \mathrm{e}+02$ & $3.739 \mathrm{e}+03$ & $5.608 \mathrm{e}+03$ \\
\hline Capsule 5 & $7.202 \mathrm{e}+02$ & $5.041 \mathrm{e}+03$ & $7.562 \mathrm{e}+03$ \\
\hline Capsule 6 & $6.413 \mathrm{e}+02$ & $4.489 \mathrm{e}+03$ & $6.734 \mathrm{e}+03$ \\
\hline
\end{tabular}

* For the orientation of capsules see Figure 6.

Table 8. Total heat rates of weapons-grade $\mathrm{MOX}$ fuel $\left(\mathrm{WGPuO}_{2} 5.0 \mathrm{wt} \%\right)$ capsules in a large Ihole in the East quadrant of ATR

\begin{tabular}{|c|c|c|c|c|c|c|c|c|}
\hline \multirow{2}{*}{ Location } & $\begin{array}{c}\text { One } \\
\text { capsule }\end{array}$ & \multicolumn{7}{|c|}{ Six capsules in large I-hole ${ }^{\mathrm{A}}$} \\
\cline { 2 - 9 } & Center & Average & 1 & 2 & 3 & 4 & 5 & 6 \\
\hline $\begin{array}{c}\text { Top 1 fuel } \\
\text { section }\end{array}$ & $6.673 \mathrm{e}-01$ & $4.560 \mathrm{e}-01$ & $3.349 \mathrm{e}-01$ & $4.604 \mathrm{e}-01$ & $5.413 \mathrm{e}-01$ & $3.920 \mathrm{e}-01$ & $5.230 \mathrm{e}-01$ & $4.846 \mathrm{e}-01$ \\
\hline 2 & $8.132 \mathrm{e}-01$ & $5.385 \mathrm{e}-01$ & $4.275 \mathrm{e}-01$ & $5.292 \mathrm{e}-01$ & $6.142 \mathrm{e}-01$ & $4.858 \mathrm{e}-01$ & $6.231 \mathrm{e}-01$ & $5.509 \mathrm{e}-01$ \\
\hline 3 & $7.680 \mathrm{e}-01$ & $5.090 \mathrm{e}-01$ & $3.731 \mathrm{e}-01$ & $5.296 \mathrm{e}-01$ & $5.833 \mathrm{e}-01$ & $4.506 \mathrm{e}-01$ & $6.040 \mathrm{e}-01$ & $5.132 \mathrm{e}-01$ \\
\hline $\begin{array}{c}\text { Bottom } 4 \\
\text { fuel } \\
\text { section }\end{array}$ & $6.477 \mathrm{e}-01$ & $4.075 \mathrm{e}-01$ & $3.081 \mathrm{e}-01$ & $4.249 \mathrm{e}-01$ & $4.681 \mathrm{e}-01$ & $3.571 \mathrm{e}-01$ & $4.621 \mathrm{e}-01$ & $4.249 \mathrm{e}-01$ \\
\hline $\begin{array}{c}\text { SST } \\
\text { cladding }\end{array}$ & $2.108 \mathrm{e}-02$ & $2.005 \mathrm{e}-02$ & $1.316 \mathrm{e}-02$ & $1.723 \mathrm{e}-02$ & $2.367 \mathrm{e}-02$ & $2.499 \mathrm{e}-02$ & $2.364 \mathrm{e}-02$ & $1.759 \mathrm{e}-02$ \\
\hline SST tube & $2.105 \mathrm{e}-02$ & $2.015 \mathrm{e}-02$ & $1.342 \mathrm{e}-02$ & $1.724 \mathrm{e}-02$ & $2.404 \mathrm{e}-02$ & $2.503 \mathrm{e}-02$ & $2.371 \mathrm{e}-02$ & $1.743 \mathrm{e}-02$ \\
\hline $\begin{array}{c}\text { Water } \\
\text { annulus }\end{array}$ & $2.858 \mathrm{e}-02$ & $3.141 \mathrm{e}-02$ & $2.193 \mathrm{e}-02$ & $2.738 \mathrm{e}-02$ & $3.668 \mathrm{e}-02$ & $3.869 \mathrm{e}-02$ & $3.644 \mathrm{e}-02$ & $2.733 \mathrm{e}-02$ \\
\hline $\begin{array}{c}\text { Outer } \\
\text { SST }\end{array}$ & $2.154 \mathrm{e}-02$ & $2.107 \mathrm{e}-02$ & $1.371 \mathrm{e}-02$ & $1.812 \mathrm{e}-02$ & $2.526 \mathrm{e}-02$ & $2.660 \mathrm{e}-02$ & $2.498 \mathrm{e}-02$ & $1.777 \mathrm{e}-02$ \\
\hline $\begin{array}{c}\text { Outer } \\
\text { water }\end{array}$ & $3.002 \mathrm{e}-02$ & $3.356 \mathrm{e}-02$ & $2.298 \mathrm{e}-02$ & $2.827 \mathrm{e}-02$ & $3.956 \mathrm{e}-02$ & $4.382 \mathrm{e}-02$ & $3.881 \mathrm{e}-02$ & $2.792 \mathrm{e}-02$ \\
\hline
\end{tabular}

A Heat rate unit $=$ watt/gram per quadrant MW.

For selected NE $30 \mathrm{MW}$ cycle, the power split over NW, NE, Center, SW and SE lobes is 17, $30,25.9,26$, and $27 \mathrm{MW}$, respectively. North-West quadrant $=23.48 \mathrm{MW}$, North-East quadrant $=36.48$, and East quadrant $=34.98 \mathrm{MW}$. 
Table 9. Burnup (MWd/MT) of weapons-grade $\mathrm{MOX}$ fuel $\left(\mathrm{WGPuO}_{2} 5.0 \mathrm{wt} \%\right)$ capsules in a large I-hole in the East quadrant of ATR

\begin{tabular}{|c|c|c|c|}
\hline Location & $\begin{array}{c}\text { Burnup (MWd/MT) } \\
\text { per irradiation cycle }\end{array}$ & $\begin{array}{c}\text { Burnup (MWd/MT) } \\
\text { per year }\end{array}$ & $\begin{array}{c}\text { Burnup (MWd/MT) } \\
\text { per 18 months }\end{array}$ \\
\hline $\begin{array}{c}\text { Single capsule in large } \\
\text { I-hole }\end{array}$ & $1.194 \mathrm{e}+03$ & $8.355 \mathrm{e}+03$ & $1.253 \mathrm{e}+04$ \\
\hline $\begin{array}{c}\text { Average of six } \\
\text { capsules }\end{array}$ & $7.728 \mathrm{e}+02$ & $5.410 \mathrm{e}+03$ & $8.114 \mathrm{e}+03$ \\
\hline \hline Capsule 1 & $5.907 \mathrm{e}+02$ & $4.135 \mathrm{e}+03$ & $6.203 \mathrm{e}+03$ \\
\hline Capsule 2 & $7.930 \mathrm{e}+02$ & $5.551 \mathrm{e}+03$ & $8.327 \mathrm{e}+03$ \\
\hline Capsule 3 & $8.901 \mathrm{e}+02$ & $6.231 \mathrm{e}+03$ & $9.346 \mathrm{e}+03$ \\
\hline Capsule 4 & $6.656 \mathrm{e}+02$ & $4.659 \mathrm{e}+03$ & $6.988 \mathrm{e}+03$ \\
\hline Capsule 5 & $8.942 \mathrm{e}+02$ & $6.259 \mathrm{e}+03$ & $9.389 \mathrm{e}+03$ \\
\hline Capsule 6 & $8.052 \mathrm{e}+02$ & $5.636 \mathrm{e}+03$ & $8.454 \mathrm{e}+03$ \\
\hline
\end{tabular}

* For the orientation of capsules see Figure 6.

Table 10. Total heat rates of weapons-grade $\mathrm{MOX}$ fuel $\left(\mathrm{WGPuO}_{2} 7.0 \mathrm{wt} \%\right)$ capsules in a large Ihole in the East quadrant of ATR

\begin{tabular}{|c|c|c|c|c|c|c|c|c|}
\hline \multirow{2}{*}{ Location } & $\begin{array}{c}\text { One } \\
\text { capsule }\end{array}$ & \multicolumn{7}{|c|}{ Six capsules in large I-hole ${ }^{\mathrm{A}}$} \\
\cline { 2 - 9 } & Center & Average & 1 & 2 & 3 & 4 & 5 & 6 \\
\hline $\begin{array}{c}\text { Top 1 fuel } \\
\text { section }\end{array}$ & $7.958 \mathrm{e}-01$ & $5.130 \mathrm{e}-01$ & $3.926 \mathrm{e}-01$ & $5.196 \mathrm{e}-01$ & $5.786 \mathrm{e}-01$ & $4.611 \mathrm{e}-01$ & $5.998 \mathrm{e}-01$ & $5.265 \mathrm{e}-01$ \\
\hline 2 & $9.115 \mathrm{e}-01$ & $6.042 \mathrm{e}-01$ & $4.438 \mathrm{e}-01$ & $6.204 \mathrm{e}-01$ & $7.202 \mathrm{e}-01$ & $5.330 \mathrm{e}-01$ & $7.321 \mathrm{e}-01$ & $5.755 \mathrm{e}-01$ \\
\hline 3 & $9.155 \mathrm{e}-01$ & $5.760 \mathrm{e}-01$ & $4.492 \mathrm{e}-01$ & $6.033 \mathrm{e}-01$ & $6.810 \mathrm{e}-01$ & $4.907 \mathrm{e}-01$ & $6.750 \mathrm{e}-01$ & $5.568 \mathrm{e}-01$ \\
\hline $\begin{array}{c}\text { Bottom } 4 \\
\text { fuel } \\
\text { section }\end{array}$ & $7.614 \mathrm{e}-01$ & $4.729 \mathrm{e}-01$ & $3.750 \mathrm{e}-01$ & $4.878 \mathrm{e}-01$ & $5.190 \mathrm{e}-01$ & $4.070 \mathrm{e}-01$ & $5.631 \mathrm{e}-01$ & $4.856 \mathrm{e}-01$ \\
\hline $\begin{array}{c}\text { SST } \\
\text { cladding }\end{array}$ & $2.163 \mathrm{e}-02$ & $2.087 \mathrm{e}-02$ & $1.418 \mathrm{e}-02$ & $1.814 \mathrm{e}-02$ & $2.431 \mathrm{e}-02$ & $2.638 \mathrm{e}-02$ & $2.448 \mathrm{e}-02$ & $1.772 \mathrm{e}-02$ \\
\hline SST tube & $2.146 \mathrm{e}-02$ & $2.079 \mathrm{e}-02$ & $1.389 \mathrm{e}-02$ & $1.808 \mathrm{e}-02$ & $2.469 \mathrm{e}-02$ & $2.630 \mathrm{e}-02$ & $2.403 \mathrm{e}-02$ & $1.775 \mathrm{e}-02$ \\
\hline $\begin{array}{c}\text { Water } \\
\text { annulus }\end{array}$ & $2.985 \mathrm{e}-02$ & $3.308 \mathrm{e}-02$ & $2.335 \mathrm{e}-02$ & $2.901 \mathrm{e}-02$ & $3.860 \mathrm{e}-02$ & $4.080 \mathrm{e}-02$ & $3.799 \mathrm{e}-02$ & $2.872 \mathrm{e}-02$ \\
\hline $\begin{array}{c}\text { Outer } \\
\text { SST }\end{array}$ & $2.191 \mathrm{e}-02$ & $2.143 \mathrm{e}-02$ & $1.416 \mathrm{e}-02$ & $1.848 \mathrm{e}-02$ & $2.564 \mathrm{e}-02$ & $2.723 \mathrm{e}-02$ & $2.504 \mathrm{e}-02$ & $1.805 \mathrm{e}-02$ \\
\hline $\begin{array}{c}\text { Outer } \\
\text { water }\end{array}$ & $3.091 \mathrm{e}-02$ & $3.487 \mathrm{e}-02$ & $2.394 \mathrm{e}-02$ & $2.980 \mathrm{e}-02$ & $4.091 \mathrm{e}-02$ & $4.509 \mathrm{e}-02$ & $4.036 \mathrm{e}-02$ & $2.910 \mathrm{e}-02$ \\
\hline
\end{tabular}

A Heat rate unit = watt/gram per quadrant MW.

For selected NE $30 \mathrm{MW}$ cycle, the power split over NW, NE, Center, SW and SE lobes is 17, $30,25.9,26$, and $27 \mathrm{MW}$, respectively. North-West quadrant $=23.48 \mathrm{MW}$, North-East quadrant $=36.48$, and East quadrant $=34.98 \mathrm{MW}$. 
Table 11. Burnup (MWd/MT) of weapons-grade $\mathrm{MOX}$ fuel $\left(\mathrm{WGPuO}_{2} 7.0 \mathrm{wt} \%\right)$ capsules in a large I-hole in the East quadrant of ATR

\begin{tabular}{|c|c|c|c|}
\hline Location & $\begin{array}{c}\text { Burnup (MWd/MT) } \\
\text { per irradiation cycle }\end{array}$ & $\begin{array}{c}\text { Burnup (MWd/MT) } \\
\text { per year }\end{array}$ & $\begin{array}{c}\text { Burnup (MWd/MT) } \\
\text { per 18 months }\end{array}$ \\
\hline $\begin{array}{c}\text { Single capsule in large } \\
\text { I-hole }\end{array}$ & $1.400 \mathrm{e}+03$ & $9.799 \mathrm{e}+03$ & $1.470 \mathrm{e}+04$ \\
\hline $\begin{array}{c}\text { Average of six } \\
\text { capsules }\end{array}$ & $8.820 \mathrm{e}+02$ & $6.174 \mathrm{e}+03$ & $9.261 \mathrm{e}+03$ \\
\hline \hline Capsule 1 & $6.838 \mathrm{e}+02$ & $4.786 \mathrm{e}+03$ & $7.180 \mathrm{e}+03$ \\
\hline Capsule 2 & $9.124 \mathrm{e}+02$ & $6.387 \mathrm{e}+03$ & $9.580 \mathrm{e}+03$ \\
\hline Capsule 3 & $1.016 \mathrm{e}+03$ & $7.109 \mathrm{e}+03$ & $1.066 \mathrm{e}+04$ \\
\hline Capsule 4 & $7.465 \mathrm{e}+02$ & $5.225 \mathrm{e}+03$ & $7.838 \mathrm{e}+03$ \\
\hline Capsule 5 & $1.046 \mathrm{e}+03$ & $7.321 \mathrm{e}+03$ & $1.098 \mathrm{e}+04$ \\
\hline Capsule 6 & $8.881 \mathrm{e}+02$ & $6.217 \mathrm{e}+03$ & $9.325 \mathrm{e}+03$ \\
\hline
\end{tabular}

* For the orientation of capsules see Figure 6.

A phenomenon related to self-shielding is the effect on the thermal neutron flux in one capsule caused by the presence of other capsules in nearby test holes. In the calculations presented in this section, only aluminum filler, which is nearly transparent to neutrons, occupies the medium and small I-holes and the B-holes near the large I-hole containing MOX fuel capsules. In the calculations presented in Section 5.2, all of the I-holes and B-holes are simultaneously filled with MOX fuel capsules. The burnup per year in the large I-holes can be seen to be cut almost in half for a single capsule in a large I-hole when the adjacent I-holes and B-holes are occupied by fuel, as compared to the case when they are occupied by aluminum filler. (Not only is the difference in the power distributions in this section and Section 5.2 too small to account for a significant part of this change in burnup, but the difference in power distributions should produce a burnup change in the opposite sense from that which is observed.)

The strong effects of self-shielding in the test fuel assemblies show dramatically that test fuel performance calculations cannot be based on the unperturbed neutron fluxes. Proper prediction of heat rates, burnup, and neutron fluxes requires the use of codes and input models that can account correctly for self-shielding in the strongly absorbing fuel. Furthermore, the performance of one test fuel capsule cannot be predicted accurately without accounting for the depression in the neutron flux caused by other nearby capsules; the neutron flux solution for a whole lobe or quadrant of the ATR must be obtained self-consistently. 
Figure 7. Calculated linear heat rates, burnups, and fast neutron fluxes of MOX fuel pins in one or six drop-in capsules in an ATR large-I hole (WG-Pu $3.0 \mathrm{wt} \%$ ).

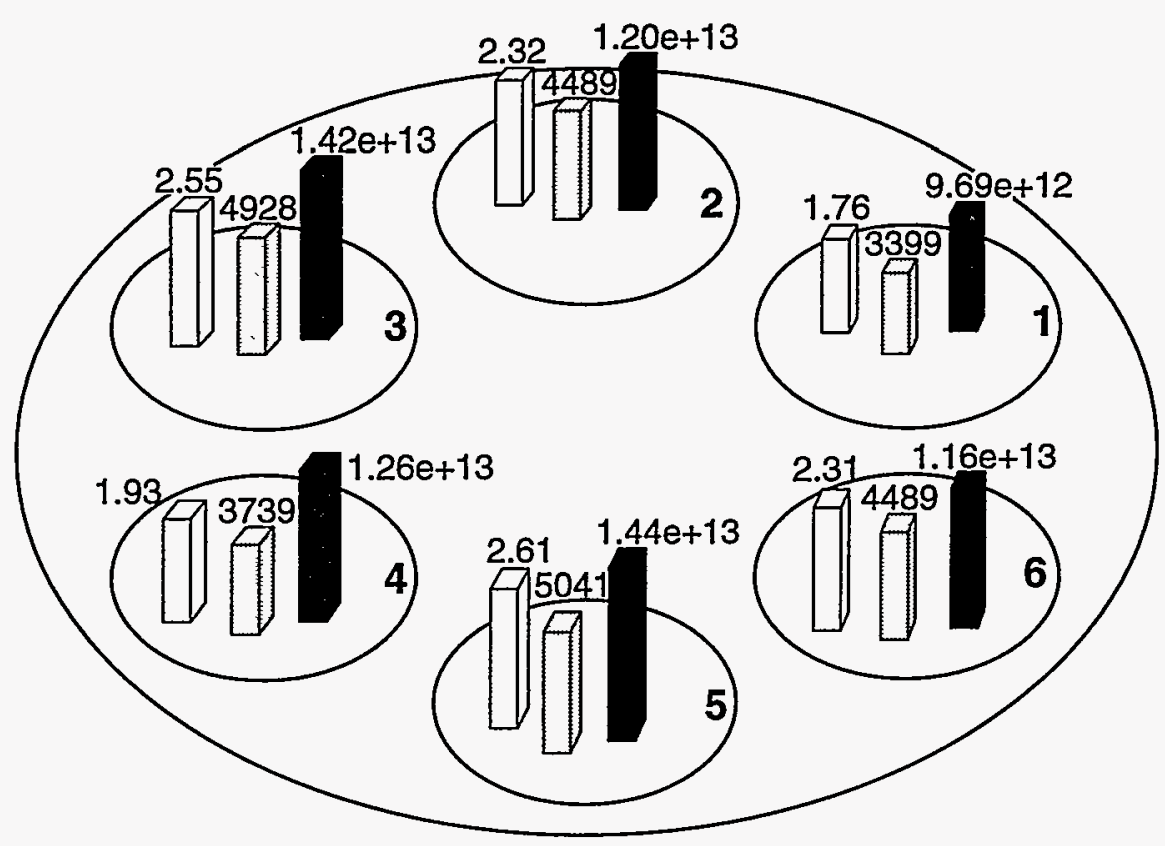

$\square \quad$ Linear heat rate $(\mathrm{kW} / \mathrm{ft})$

$\square$ Burnup (MWd/MT per year)

Fast neutron flux $>1 \mathrm{MeV}\left(\mathrm{n} / \mathrm{cm}^{2}-\mathrm{sec}\right)$

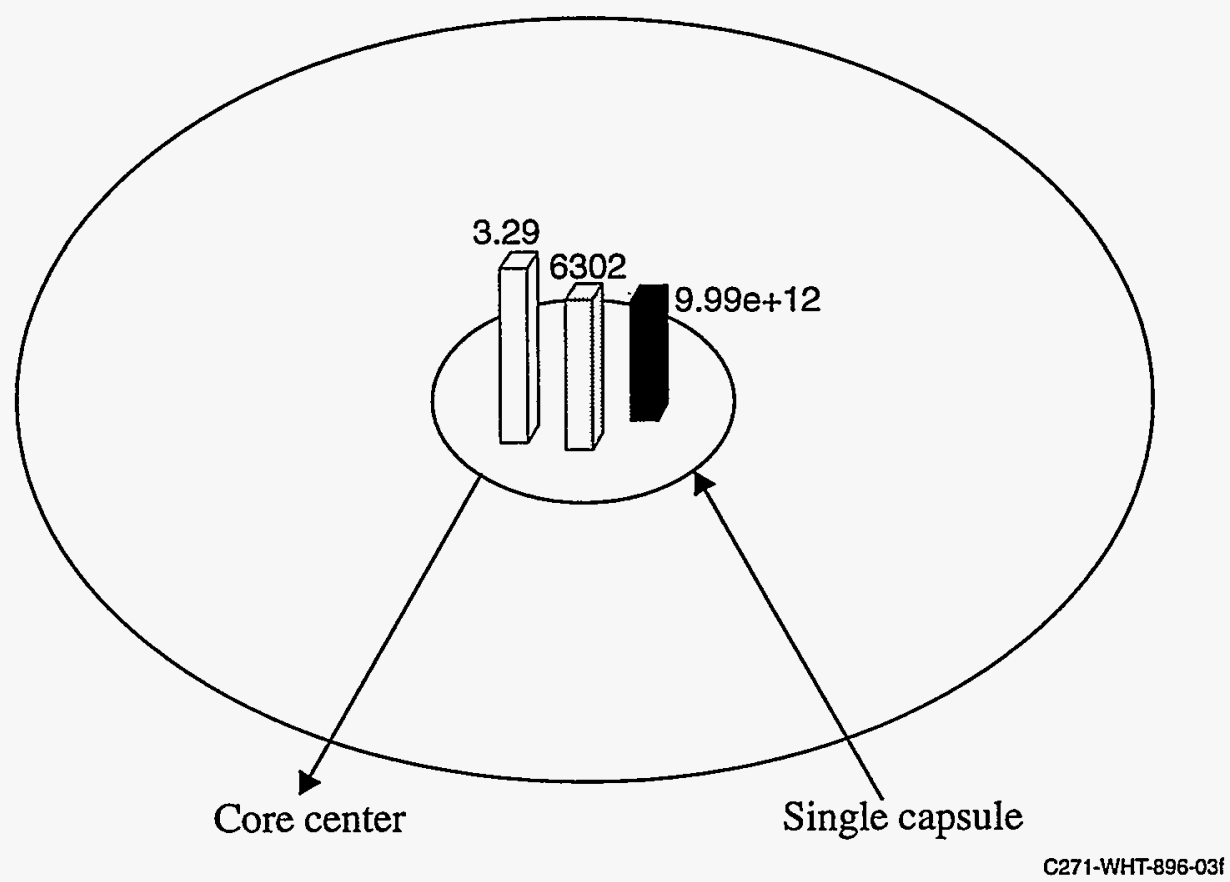


Figure 8. Calculated linear heat rates, burnups, and fast neutron fluxes of MOX fuel pins in one or six drop-in capsules in an ATR large-I hole (WG-Pu $5.0 \mathrm{wt} \%$ ).

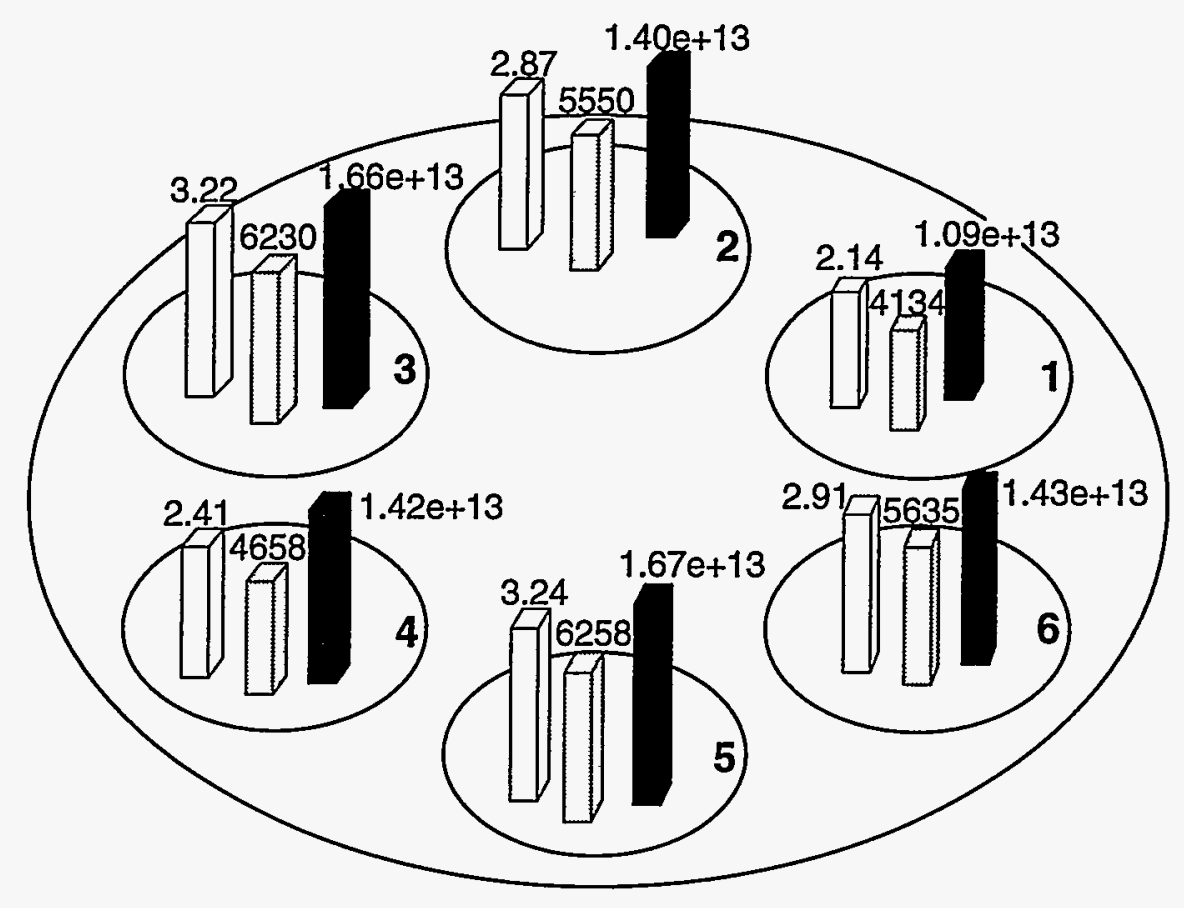

$\square \quad$ Linear heat rate $(\mathrm{kW} / \mathrm{ft})$

$\square$ Burnup (MWd/MT per year)

Fast neutron flux $>1 \mathrm{MeV}\left(\mathrm{n} / \mathrm{cm}^{2}-\mathrm{sec}\right)$

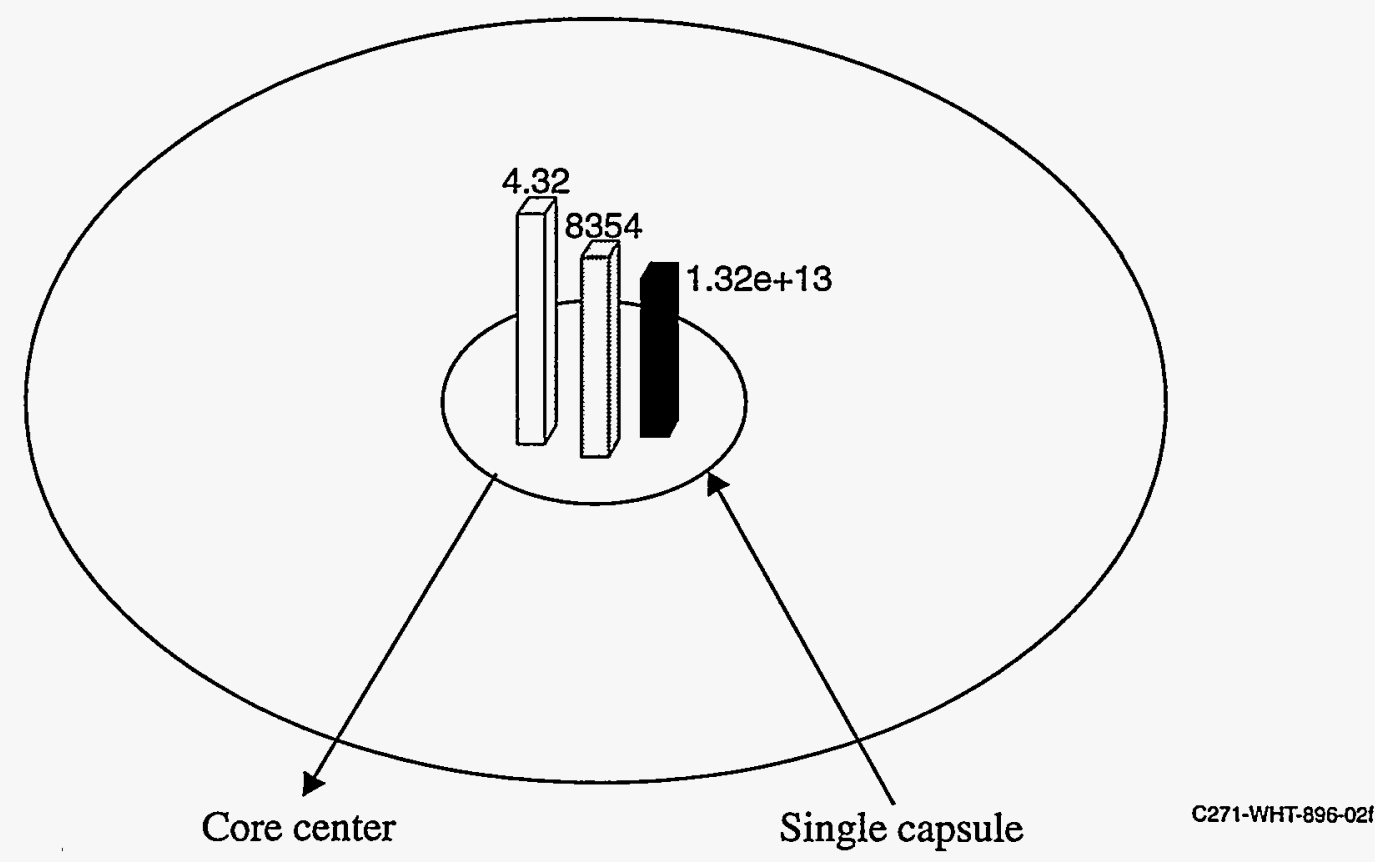


Figure 9. Calculated linear heat rates, burnups, and fast neutron fluxes of MOX fuel pins in one or six drop-in capsules in an ATR large-I hole (WG-Pu $7.0 \mathrm{wt} \%$ ).

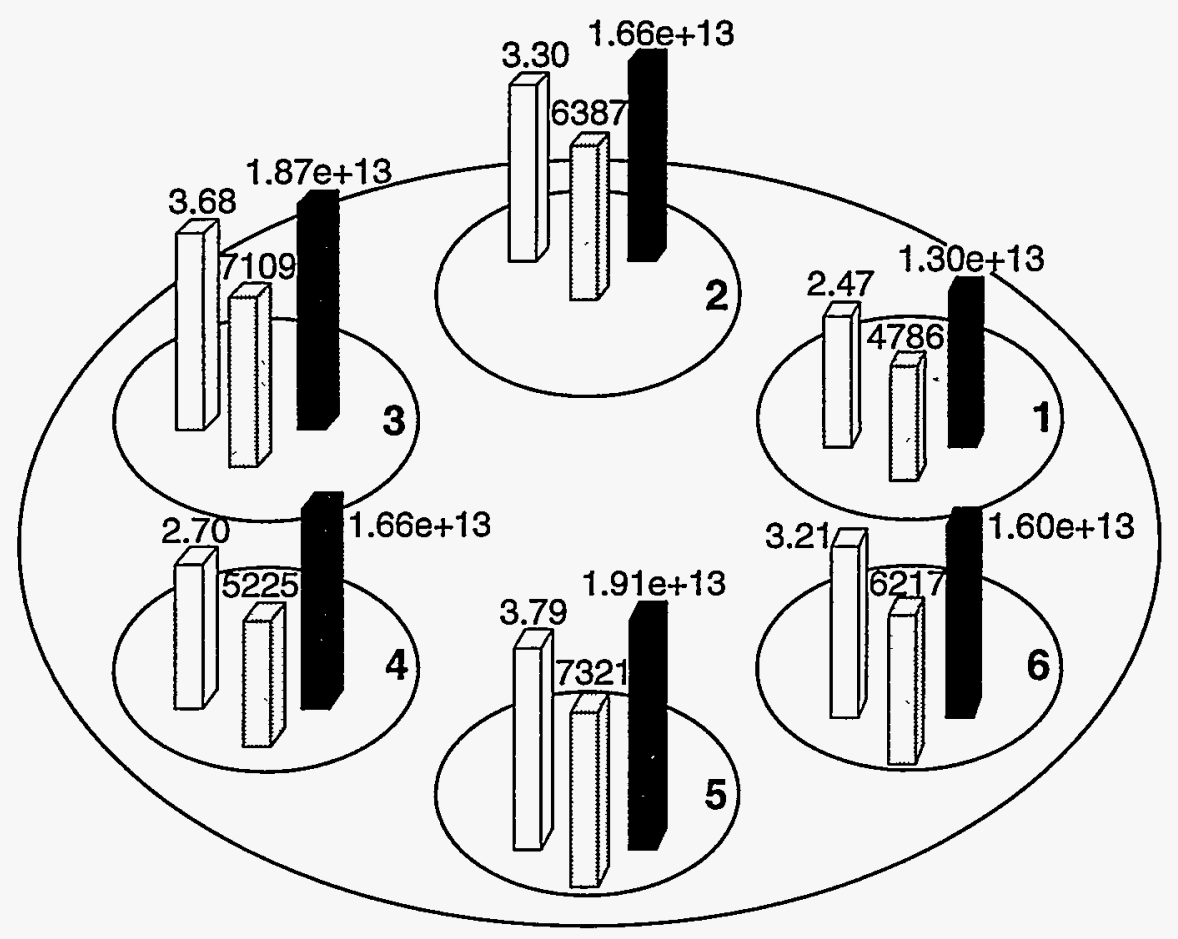

$\square$ Linear heat rate $(\mathrm{kW} / \mathrm{ft})$

$\square$ Burnup (MWd/MT per year)

Fast neutron flux $>1 \mathrm{MeV}\left(\mathrm{n} / \mathrm{cm}^{2}-\mathrm{sec}\right)$

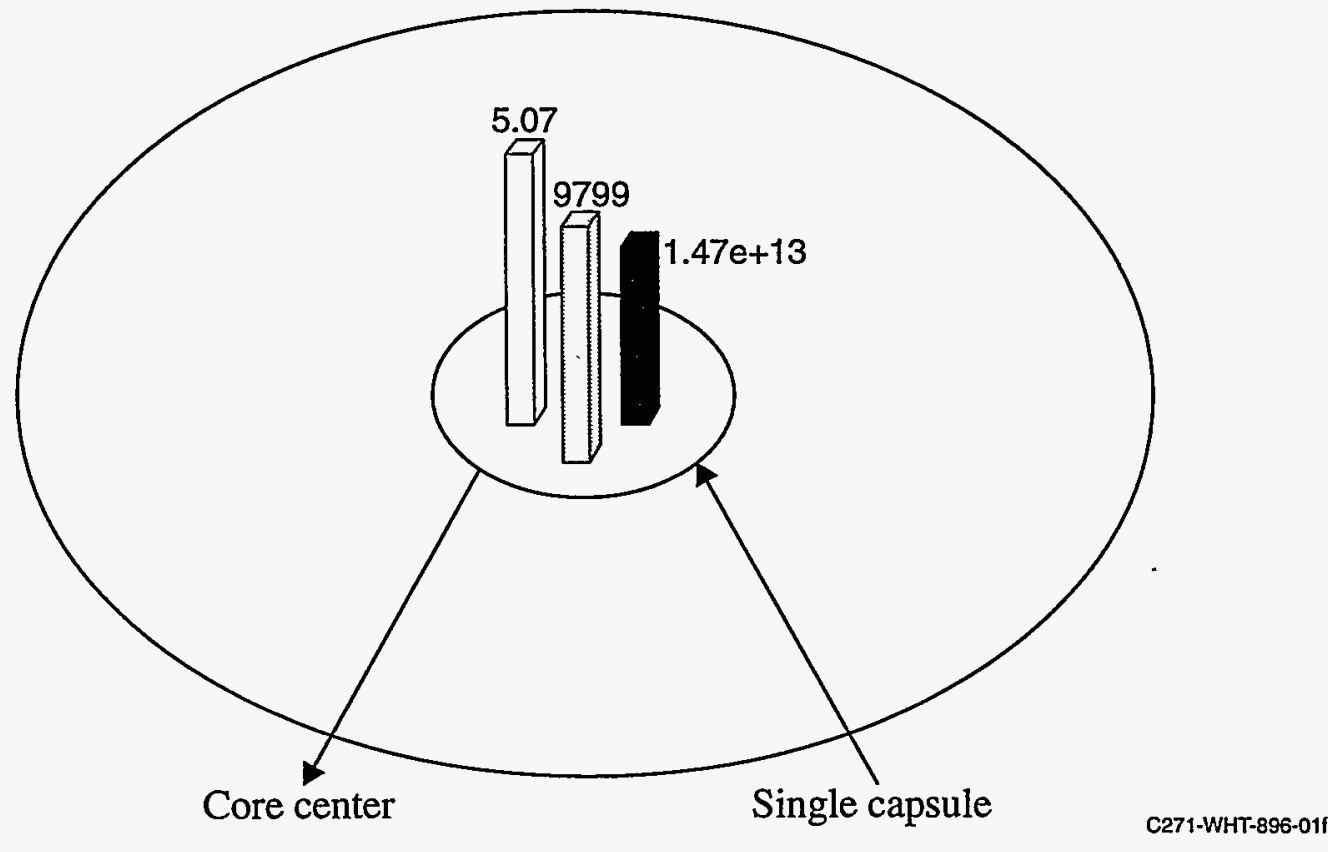




\subsection{Single MOX Fuel Pins in I-Holes and B-Holes}

For this group of calculations, the ATR power distribution was assumed to be the same as for ATR Cycle 110-B, which is expected to be typical of most future cycles. In Cycle 110-B, the power distribution in the NW, NE, Center, SW, and SE lobes was 17, 30, 27, 22, and $29 \mathrm{MW}$, respectively, for a total thermal power of $125 \mathrm{MW}$. At the beginning of the first such cycle after placement in the reactor, single PWR-type fuel pins in small, medium, and large I-holes and in small and large B-holes in the East quadrant of the ATR would generate total heat rates as displayed in Table 12 for $\mathrm{MOX}$ fuel containing $\mathrm{WGPuO}_{2}$ at a concentration of $3.0 \mathrm{wt} \%$. The Iholes are all located beyond the hafnium control drums from the core, so the heating rates achieved by pins placed in these holes are low compared to those in pins placed in the B-holes, which are located between the core and the hafnium drums. The heat rates in the small and medium I-holes are greater than the ones in the large I-hole, because these holes are located closer to core fuel elements. But the large I-holes offer considerably greater capacity. Table 13 shows specific power, linear heat rates, and burnup for the same conditions. Tables 14-17 show analogous quantities for PWR MOX fuel pins containing $\mathrm{WGPuO}_{2}$ at concentrations of 5.0 and $7.0 \mathrm{wt} \%$. Tables 18-23 show the same data as Tables 12-17, but for BWR-type fuel pins. The BWR-type pellets have a diameter of $1.056 \mathrm{~cm}$, as opposed to $0.819 \mathrm{~cm}$ for the PWR-type pellets.

The heat rates for PWR pellets in the small I-hole are closest to those in a commercial PWR (in which the maximum linear heat rate is $12.99 \mathrm{~kW} / \mathrm{ft}$ ), although the heat rates in the small I-holes are in all cases larger than those in the PWR and usually too large for temperatures to remain within acceptable limits (see the discussion below on thermohydraulics analyses). The heat rates for BWR pellets are closest to those in a commercial BWR (in which the maximum linear heat rate is $13.41 \mathrm{~kW} / \mathrm{ft}$ ) in the small or medium I-hole, depending on $\mathrm{WGPuO}_{2}$ concentration in the $\mathrm{MOX}$ fuel. Again, however, the heat rates in the small I-holes are too high for thermal limits to be met. The linear heat rates and total heat rates per pin for BWR fuel are higher than those for PWR fuel, because the BWR fuel pellets have greater diameter. However, the specific power for PWR fuel is higher: the increase in linear heat rate is not proportional to the increase in pellet volume from PWR fuel to BWR fuel because of self-shielding. Furthermore, self-shielding prevents proportionate increases in heat rates when the $\mathrm{WGPuO}_{2}$ concentration increases from $3 \%$ to $5 \%$ and $7 \%$. The BWR pins experience more self-shielding because they are larger in diameter. 
Table 12. Total heat rates of PWR weapons-grade $\mathrm{MOX}$ fuel $\left(\mathrm{WGPuO}_{2} 3.0 \mathrm{wt} \%\right)$ capsules in small I, medium I, large I, small B, and large B-holes in the East quadrant of ATR

\begin{tabular}{|c|c|c|c|c|c|}
\cline { 2 - 6 } \multicolumn{1}{c|}{} & \multicolumn{5}{c|}{ Total heat rates (W/g per quadrant MW) } \\
\hline Location & Small I-hole & Medium I & Large I & Small B & Large B \\
\hline $\begin{array}{c}\text { Bottom 1 fuel } \\
\text { section }\end{array}$ & $2.118 \mathrm{e}+00$ & $4.890 \mathrm{e}-01$ & $2.536 \mathrm{e}-01$ & $6.990 \mathrm{e}+00$ & $3.712 \mathrm{e}+00$ \\
\hline 2 & $2.380 \mathrm{e}+00$ & $5.448 \mathrm{e}-01$ & $3.213 \mathrm{e}-01$ & $8.032 \mathrm{e}+00$ & $4.290 \mathrm{e}+00$ \\
\hline 3 & $2.062 \mathrm{e}+00$ & $4.936 \mathrm{e}-01$ & $2.617 \mathrm{e}-01$ & $7.427 \mathrm{e}+00$ & $3.976 \mathrm{e}+00$ \\
\hline $\begin{array}{c}\text { Top 4 fuel } \\
\text { section }\end{array}$ & $1.684 \mathrm{e}+00$ & $3.903 \mathrm{e}-01$ & $2.241 \mathrm{e}-01$ & $6.003 \mathrm{e}+00$ & $3.221 \mathrm{e}+00$ \\
\hline SST cladding & $4.208 \mathrm{e}-02$ & $2.150 \mathrm{e}-02$ & $1.661 \mathrm{e}-02$ & $1.975 \mathrm{e}-01$ & $1.241 \mathrm{e}-01$ \\
\hline SST tube & $4.165 \mathrm{e}-02$ & $2.185 \mathrm{e}-02$ & $1.696 \mathrm{e}-02$ & $1.956 \mathrm{e}-01$ & $1.231 \mathrm{e}-01$ \\
\hline Water annulus & $5.648 \mathrm{e}-02$ & $2.923 \mathrm{e}-02$ & $2.235 \mathrm{e}-02$ & $4.280 \mathrm{e}-01$ & $1.979 \mathrm{e}-01$ \\
\hline Outer SST & $4.284 \mathrm{e}-02$ & $2.275 \mathrm{e}-02$ & $1.802 \mathrm{e}-02$ & $2.022 \mathrm{e}-01$ & $1.273 \mathrm{e}-01$ \\
\hline Outer water & $5.442 \mathrm{e}-02$ & $3.233 \mathrm{e}-02$ & $2.561 \mathrm{e}-02$ & $4.745 \mathrm{e}-01$ & $2.116 \mathrm{e}-01$ \\
\hline
\end{tabular}

For typical NE 30 MW cycle (110-B), the power split over NW, NE, Center, SW and SE lobes is $17,30,27,22$, and $29 \mathrm{MW}$, respectively. North-West quadrant $=23.75 \mathrm{MW}$, North-East quadrant $=36.75$, and East quadrant $=36.25 \mathrm{MW}$.

Fuel pellet diameter $=0.819 \mathrm{~cm}$, and density $=10.54 \mathrm{~g} / \mathrm{cc}$.

Table 13. Comparison of maximum linear power density and burnup (MWd/MT) of weaponsgrade $\mathrm{MOX}$ fuel $\left(\mathrm{WGPuO}_{2} 3.0 \mathrm{wt} \%\right)$ capsules in the East quadrant of ATR* and a typical PWR $\mathrm{UO}_{2}$ fuel

\begin{tabular}{|c|c|c|c|c|}
\hline Location & $\begin{array}{c}\text { Specific power } \\
(\mathrm{W} / \mathrm{g})\end{array}$ & $\begin{array}{c}\text { Max. linear } \\
\text { power density } \\
(\mathrm{kW} / \mathrm{ft})\end{array}$ & $\begin{array}{c}\text { Max. linear } \\
\text { power density } \\
(\mathrm{W} / \mathrm{cm})\end{array}$ & $\begin{array}{c}\text { Burnup } \\
\text { (MWD/MT) } \\
\text { per year }\end{array}$ \\
\hline PWR $^{* \mathrm{UO}_{2} \text { fuel }}$ & $7.528 \mathrm{e}+01$ & $1.299 \mathrm{e}+01$ & $4.260 \mathrm{e}+02$ & $2.258 \mathrm{e}+04$ \\
\hline \hline Small I & $8.492 \mathrm{e}+01$ & $1.465 \mathrm{e}+01$ & $4.805 \mathrm{e}+02$ & $2.796 \mathrm{e}+04$ \\
\hline Medium I & $1.895 \mathrm{e}+01$ & $3.269 \mathrm{e}+00$ & $1.072 \mathrm{e}+02$ & $6.240 \mathrm{e}+03$ \\
\hline Large I & $1.009 \mathrm{e}+01$ & $1.741 \mathrm{e}+00$ & $5.712 \mathrm{e}+01$ & $3.324 \mathrm{e}+03$ \\
\hline Small B & $2.882 \mathrm{e}+02$ & $4.971 \mathrm{e}+01$ & $1.631 \mathrm{e}+03$ & $9.489 \mathrm{e}+04$ \\
\hline Large B & $1.523 \mathrm{e}+02$ & $2.627 \mathrm{e}+01$ & $8.617 \mathrm{e}+02$ & $5.014 \mathrm{e}+04$ \\
\hline
\end{tabular}

* For typical NE $30 \mathrm{MW}$ cycle (110-B), the power split over NW, NE, Center, SW and SE lobes is $17,30,27,22$, and $29 \mathrm{MW}$, respectively. North-West quadrant $=23.75 \mathrm{MW}$, North-East quadrant $=36.75$, and East quadrant $=36.25 \mathrm{MW}$. The quarter-core $\mathrm{MCNP}$ model is based on the middle of 110-B cycle fuel loading in the East quadrant with outer shim control drums at SE $85.40^{\circ}$ and NE $79.30^{\circ}$. There are 7 cycles per year at 42 effective full power days per cycle.

** Assume 300 full power days per year with thermal output $3411 \mathrm{MWt}$. 
Table 14. Total heat rates of PWR weapons-grade $\mathrm{MOX}$ fuel $\left(\mathrm{WGPuO}_{2} 5.0 \mathrm{wt} \%\right)$ capsules in small I, medium I, large I, small B, and large B-holes in the East quadrant of ATR

\begin{tabular}{|c|c|c|c|c|c|}
\cline { 2 - 6 } \multicolumn{1}{c|}{} & \multicolumn{5}{c|}{ Total heat rates (W/g) per quadrant MW } \\
\hline Location & Small I-hole & Medium I & Large I & Small B & Large B \\
\hline $\begin{array}{c}\text { Bottom 1 fuel } \\
\text { section }\end{array}$ & $2.539 \mathrm{e}+00$ & $6.385 \mathrm{e}-01$ & $3.344 \mathrm{e}-01$ & $9.124 \mathrm{e}+00$ & $4.849 \mathrm{e}+00$ \\
\hline 2 & $2.928 \mathrm{e}+00$ & $7.278 \mathrm{e}-01$ & $4.005 \mathrm{e}-01$ & $1.037 \mathrm{e}+01$ & $5.483 \mathrm{e}+00$ \\
\hline 3 & $2.840 \mathrm{e}+00$ & $6.913 \mathrm{e}-01$ & $3.911 \mathrm{e}-01$ & $9.724 \mathrm{e}+00$ & $5.280 \mathrm{e}+00$ \\
\hline $\begin{array}{c}\text { Top 4 fuel } \\
\text { section }\end{array}$ & $2.378 \mathrm{e}+00$ & $5.606 \mathrm{e}-01$ & $3.049 \mathrm{e}-01$ & $8.099 \mathrm{e}+00$ & $4.189 \mathrm{e}+00$ \\
\hline SST cladding & $4.457 \mathrm{e}-02$ & $2.213 \mathrm{e}-02$ & $1.729 \mathrm{e}-02$ & $2.077 \mathrm{e}-01$ & $1.303 \mathrm{e}-01$ \\
\hline SST tube & $4.316 \mathrm{e}-02$ & $2.232 \mathrm{e}-02$ & $1.718 \mathrm{e}-02$ & $2.043 \mathrm{e}-01$ & $1.283 \mathrm{e}-01$ \\
\hline Water annulus & $6.119 \mathrm{e}-02$ & $3.052 \mathrm{e}-02$ & $2.305 \mathrm{e}-02$ & $4.467 \mathrm{e}-01$ & $2.103 \mathrm{e}-01$ \\
\hline Outer SST & $4.350 \mathrm{e}-02$ & $2.315 \mathrm{e}-02$ & $1.802 \mathrm{e}-02$ & $2.068 \mathrm{e}-01$ & $1.298 \mathrm{e}-01$ \\
\hline Outer water & $5.666 \mathrm{e}-02$ & $3.349 \mathrm{e}-02$ & $2.613 \mathrm{e}-02$ & $4.849 \mathrm{e}-01$ & $2.176 \mathrm{e}-01$ \\
\hline
\end{tabular}

For typical NE $30 \mathrm{MW}$ cycle (110-B), the power split over NW, NE, Center, SW and SE lobes is $17,30,27,22$, and $29 \mathrm{MW}$, respectively. North-West quadrant $=23.75 \mathrm{MW}$, North-East quadrant $=36.75$, and East quadrant $=36.25 \mathrm{MW}$.

Fuel pellet diameter $=0.819 \mathrm{~cm}$, and density $=10.54 \mathrm{~g} / \mathrm{cc}$.

Table 15. Comparison of maximum linear power density and burnup (MWd/MT) of weaponsgrade $\mathrm{MOX}$ fuel $\left(\mathrm{WGPuO}_{2} 5.0 \mathrm{wt} \%\right)$ capsules in the East quadrant of ATR* and a typical PWR $\mathrm{UO}_{2}$ fuel

\begin{tabular}{|c|c|c|c|c|}
\hline Location & $\begin{array}{c}\text { Specific power } \\
\text { (W/g) }\end{array}$ & $\begin{array}{c}\text { Max. linear } \\
\text { power density } \\
(\mathrm{kW} / \mathrm{ft})\end{array}$ & $\begin{array}{c}\text { Max. linear } \\
\text { power density } \\
(\mathrm{W} / \mathrm{cm})\end{array}$ & $\begin{array}{c}\text { Burnup } \\
\text { (MWD/MT) } \\
\text { per year }\end{array}$ \\
\hline PWR $\mathrm{UO}_{2}$ fuel & $7.528 \mathrm{e}+01$ & $1.299 \mathrm{e}+01$ & $4.260 \mathrm{e}+02$ & $2.258 \mathrm{e}+04$ \\
\hline \hline Small I & $1.107 \mathrm{e}+02$ & $1.910 \mathrm{e}+01$ & $6.265 \mathrm{e}+02$ & $3.646 \mathrm{e}+04$ \\
\hline Medium I & $2.635 \mathrm{e}+01$ & $4.545 \mathrm{e}+00$ & $1.491 \mathrm{e}+02$ & $8.675 \mathrm{e}+03$ \\
\hline Large I & $1.399 \mathrm{e}+01$ & $2.414 \mathrm{e}+00$ & $7.918 \mathrm{e}+01$ & $4.607 \mathrm{e}+03$ \\
\hline Small B & $3.814 \mathrm{e}+02$ & $6.578 \mathrm{e}+01$ & $2.158 \mathrm{e}+03$ & $1.256 \mathrm{e}+05$ \\
\hline Large B & $2.014 \mathrm{e}+02$ & $3.473 \mathrm{e}+01$ & $1.139 \mathrm{e}+03$ & $6.630 \mathrm{e}+04$ \\
\hline
\end{tabular}

* For typical NE $30 \mathrm{MW}$ cycle (110-B), the power split over NW, NE, Center, SW and SE lobes is $17,30,27,22$, and $29 \mathrm{MW}$, respectively. North-West quadrant $=23.75 \mathrm{MW}$, North-East quadrant $=36.75$, and East quadrant $=36.25 \mathrm{MW}$. The quarter core $\mathrm{MCNP}$ model is based on the middle of 110-B cycle fuel loading in the East quadrant with outer shim control drums at SE $85.40^{\circ}$ and $\mathrm{NE} 79.30^{\circ}$. There are 7 cycles per year at 42 effective full power days per cycle.

** Assume 300 full power days per year with thermal output $3411 \mathrm{MWt}$. 
Table 16. Total heat rates of PWR weapons-grade $\mathrm{MOX}$ fuel $\left(\mathrm{WGPuO}_{2} 7.0 \mathrm{wt} \%\right)$ capsules in small I, medium I, large I, small B, and large B-holes in the East quadrant of ATR

\begin{tabular}{|c|c|c|c|c|c|}
\cline { 2 - 6 } \multicolumn{1}{c|}{} & \multicolumn{5}{c|}{ Total heat rates (W/g) per quadrant MW } \\
\hline Location & Small I-hole & Medium I & Large I & Small B & Large B \\
\hline $\begin{array}{c}\text { Bottom 1 fuel } \\
\text { section }\end{array}$ & $3.209 \mathrm{e}+00$ & $7.286 \mathrm{e}-01$ & $3.962 \mathrm{e}-01$ & $1.039 \mathrm{e}+01$ & $5.558 \mathrm{e}+00$ \\
\hline 2 & $3.629 \mathrm{e}+00$ & $8.433 \mathrm{e}-01$ & $4.580 \mathrm{e}-01$ & $1.184 \mathrm{e}+01$ & $6.119 \mathrm{e}+00$ \\
\hline 3 & $3.547 \mathrm{e}+00$ & $7.955 \mathrm{e}-01$ & $4.551 \mathrm{e}-01$ & $1.126 \mathrm{e}+01$ & $6.114 \mathrm{e}+00$ \\
\hline $\begin{array}{c}\text { Top 4 fuel } \\
\text { section }\end{array}$ & $2.751 \mathrm{e}+00$ & $6.448 \mathrm{e}-01$ & $3.156 \mathrm{e}-01$ & $9.229 \mathrm{e}+00$ & $4.822 \mathrm{e}+00$ \\
\hline SST cladding & $4.724 \mathrm{e}-02$ & $2.347 \mathrm{e}-02$ & $1.679 \mathrm{e}-02$ & $2.119 \mathrm{e}-01$ & $1.309 \mathrm{e}-01$ \\
\hline SST tube & $4.556 \mathrm{e}-02$ & $2.374 \mathrm{e}-02$ & $1.730 \mathrm{e}-02$ & $2.059 \mathrm{e}-01$ & $1.287 \mathrm{e}-01$ \\
\hline Water annulus & $6.687 \mathrm{e}-02$ & $3.246 \mathrm{e}-02$ & $2.360 \mathrm{e}-02$ & $4.598 \mathrm{e}-01$ & $2.150 \mathrm{e}-01$ \\
\hline Outer SST & $4.451 \mathrm{e}-02$ & $2.414 \mathrm{e}-02$ & $1.816 \mathrm{e}-02$ & $2.078 \mathrm{e}-01$ & $1.291 \mathrm{e}-01$ \\
\hline Outer water & $5.896 \mathrm{e}-02$ & $3.461 \mathrm{e}-02$ & $2.655 \mathrm{e}-02$ & $4.920 \mathrm{e}-01$ & $2.215 \mathrm{e}-01$ \\
\hline
\end{tabular}

For typical NE $30 \mathrm{MW}$ cycle (110-B), the power split over NW, NE, Center, SW and SE lobes is $17,30,27,22$, and $29 \mathrm{MW}$, respectively. North-West quadrant $=23.75 \mathrm{MW}$, North-East quadrant $=36.75$, and East quadrant $=36.25 \mathrm{MW}$.

Fuel pellet diameter $=0.819 \mathrm{~cm}$, and density $=10.54 \mathrm{~g} / \mathrm{cc}$.

Table 17. Comparison of maximum linear power density and burnup (MWd/MT) of weaponsgrade MOX fuel (WGPuO $7.0 \mathrm{wt} \%$ ) capsules in the East quadrant of ATR* and a typical PWR $\mathrm{UO}_{2}$ fuel

\begin{tabular}{|c|c|c|c|c|}
\hline Location & $\begin{array}{c}\text { Specific power } \\
(\mathrm{W} / \mathrm{g})\end{array}$ & $\begin{array}{c}\text { Max. linear } \\
\text { power density } \\
(\mathrm{kW} / \mathrm{ft})\end{array}$ & $\begin{array}{c}\text { Max. linear } \\
\text { power density } \\
(\mathrm{W} / \mathrm{cm})\end{array}$ & $\begin{array}{c}\text { Burnup } \\
\text { (MWD/MT) } \\
\text { per year }\end{array}$ \\
\hline PWR $\mathrm{UO}_{2}$ fuel & $7.528 \mathrm{e}+01$ & $1.299 \mathrm{e}+01$ & $4.260 \mathrm{e}+02$ & $2.258 \mathrm{e}+04$ \\
\hline \hline Small I & $1.363 \mathrm{e}+02$ & $2.350 \mathrm{e}+01$ & $7.711 \mathrm{e}+02$ & $4.487 \mathrm{e}+04$ \\
\hline Medium I & $3.070 \mathrm{e}+01$ & $5.296 \mathrm{e}+00$ & $1.737 \mathrm{e}+02$ & $1.011 \mathrm{e}+04$ \\
\hline Large I & $1.611 \mathrm{e}+01$ & $2.778 \mathrm{e}+00$ & $9.114 \mathrm{e}+01$ & $5.303 \mathrm{e}+03$ \\
\hline Small B & $4.408 \mathrm{e}+02$ & $7.604 \mathrm{e}+01$ & $2.495 \mathrm{e}+03$ & $1.452 \mathrm{e}+05$ \\
\hline Large B & $2.323 \mathrm{e}+02$ & $4.007 \mathrm{e}+01$ & $1.314 \mathrm{e}+03$ & $7.648 \mathrm{e}+04$ \\
\hline
\end{tabular}

* For typical NE $30 \mathrm{MW}$ cycle (110-B), the power split over NW, NE, Center, SW and SE lobes is $17,30,27,22$, and $29 \mathrm{MW}$, respectively. North-West quadrant $=23.75 \mathrm{MW}$, North-East quadrant $=36.75$, and East quadrant $=36.25 \mathrm{MW}$. The quarter core MCNP model is based on the middle of 110-B cycle fuel loading in the East quadrant with outer shim control drums at SE $85.40^{\circ}$ and $\mathrm{NE} 79.30^{\circ}$. There are 7 cycles per year at 42 effective full power days per cycle.

Assume 300 full power days per year with thermal output $3411 \mathrm{MWt}$. 
Table 18. Total heat rates of $\mathrm{BWR}$ weapons-grade $\mathrm{MOX}$ fuel ( $\mathrm{WGPuO}_{2} 3.0$ wt\%) capsules in small I, medium I, large I, small B, and large B-holes in the East quadrant of ATR

\begin{tabular}{|c|c|c|c|c|c|}
\cline { 2 - 6 } \multicolumn{1}{c|}{} & \multicolumn{5}{c|}{ Total heat rates (W/g) per quadrant MW } \\
\hline $\begin{array}{c}\text { Location } \\
\text { Bottom 1 fuel } \\
\text { section }\end{array}$ & Small I-hole & Medium I & Large I & Small B & Large B \\
\hline 2 & $1.756 \mathrm{e}+00$ & $4.365 \mathrm{e}-01$ & $2.325 \mathrm{e}-01$ & $6.842 \mathrm{e}+00$ & $3.166 \mathrm{e}+00$ \\
\hline 3 & $1.930 \mathrm{e}+00$ & $4.634 \mathrm{e}-01$ & $2.345 \mathrm{e}-01$ & $7.462 \mathrm{e}+00$ & $3.463 \mathrm{e}+00$ \\
\hline $\begin{array}{c}\text { Top 4 fuel } \\
\text { section }\end{array}$ & $1.581 \mathrm{e}+00$ & $3.625 \mathrm{e}-01$ & $1.820 \mathrm{e}-01$ & $5.940 \mathrm{e}+00$ & $2.745 \mathrm{e}+00$ \\
\hline SST cladding & $4.157 \mathrm{e}-02$ & $2.138 \mathrm{e}-02$ & $1.588 \mathrm{e}-02$ & $2.017 \mathrm{e}-01$ & $1.203 \mathrm{e}-01$ \\
\hline SST tube & $4.100 \mathrm{e}-02$ & $2.187 \mathrm{e}-02$ & $1.633 \mathrm{e}-02$ & $2.057 \mathrm{e}-01$ & $1.200 \mathrm{e}-01$ \\
\hline Water annulus & $5.880 \mathrm{e}-02$ & $3.042 \mathrm{e}-02$ & $2.277 \mathrm{e}-02$ & $4.430 \mathrm{e}-01$ & $2.032 \mathrm{e}-01$ \\
\hline Outer SST & $4.252 \mathrm{e}-02$ & $2.278 \mathrm{e}-02$ & $1.754 \mathrm{e}-02$ & $2.189 \mathrm{e}-01$ & $1.259 \mathrm{e}-01$ \\
\hline Outer water & $5.766 \mathrm{e}-02$ & $3.410 \mathrm{e}-02$ & $2.617 \mathrm{e}-02$ & $4.877 \mathrm{e}-01$ & $2.187 \mathrm{e}-01$ \\
\hline
\end{tabular}

For typical NE $30 \mathrm{MW}$ cycle (110-B), the power split over NW, NE, Center, SW and SE lobes is $17,30,27,22$, and $29 \mathrm{MW}$, respectively. North-West quadrant $=23.75 \mathrm{MW}$, North-East quadrant $=36.75$, and East quadrant $=36.25 \mathrm{MW}$.

Fuel pellet diameter $=1.056 \mathrm{~cm}$, and density $=10.54 \mathrm{~g} / \mathrm{cc}$.

Table 19. Comparison of maximum linear power density and burnup (MWd/MT) of weaponsgrade $\mathrm{MOX}$ fuel $\left(\mathrm{WGPuO}_{2} 3.0 \mathrm{wt} \%\right)$ capsules in the East quadrant of ATR* and a typical BWR $\mathrm{UO}_{2}$ fuel

\begin{tabular}{|c|c|c|c|c|}
\hline Location & $\begin{array}{c}\text { Specific power } \\
\text { (W/g) }\end{array}$ & $\begin{array}{c}\text { Max. linear } \\
\text { power density } \\
(\mathrm{kW} / \mathrm{ft})\end{array}$ & $\begin{array}{c}\text { Max. linear } \\
\text { power density } \\
(\mathrm{W} / \mathrm{cm})\end{array}$ & $\begin{array}{c}\text { Burnup } \\
\text { (MWD/MT) } \\
\text { per year }\end{array}$ \\
\hline BWR $^{* \mathrm{UO}_{2} \text { fuel }}$ & $4.767 \mathrm{e}+01$ & $1.341 \mathrm{e}+01$ & $4.400 \mathrm{e}+02$ & $1.430 \mathrm{e}+04$ \\
\hline \hline Small I & $7.415 \mathrm{e}+01$ & $2.087 \mathrm{e}+01$ & $6.845 \mathrm{e}+02$ & $2.442 \mathrm{e}+04$ \\
\hline Medium I & $1.683 \mathrm{e}+01$ & $4.735 \mathrm{e}+00$ & $1.553 \mathrm{e}+02$ & $5.540 \mathrm{e}+03$ \\
\hline Large I & $8.600 \mathrm{e}+00$ & $2.420 \mathrm{e}+00$ & $7.939 \mathrm{e}+01$ & $2.832 \mathrm{e}+03$ \\
\hline Small B & $2.853 \mathrm{e}+02$ & $8.029 \mathrm{e}+01$ & $2.634 \mathrm{e}+03$ & $9.395 \mathrm{e}+04$ \\
\hline Large B & $1.292 \mathrm{e}+02$ & $3.637 \mathrm{e}+01$ & $1.193 \mathrm{e}+03$ & $4.256 \mathrm{e}+04$ \\
\hline
\end{tabular}

- For typical NE $30 \mathrm{MW}$ cycle (110-B), the power split over NW, NE, Center, SW and SE lobes is $17,30,27,22$, and $29 \mathrm{MW}$, respectively. North-West quadrant $=23.75 \mathrm{MW}$, North-East quadrant $=36.75$, and East quadrant $=36.25 \mathrm{MW}$. The quarter core MCNP model is based on the middle of 110-B cycle fuel loading in the East quadrant with outer shim control drums at SE $85.40^{\circ}$ and $\mathrm{NE} 79.30^{\circ}$. There are 7 cycles per year at 42 effective full power days per cycle.

** Assume 300 full power days per year with thermal output $3579 \mathrm{MWt}$. 
Table 20. Total heat rates of BWR weapons-grade $\mathrm{MOX}$ fuel $\left(\mathrm{WGPuO}_{2} 5.0 \mathrm{wt} \%\right)$ capsules in small I, medium I, large I, small B, and large B-holes in the East quadrant of ATR

\begin{tabular}{|c|c|c|c|c|c|}
\cline { 2 - 6 } \multicolumn{1}{c|}{} & \multicolumn{5}{c|}{ Total heat rates (W/g) per quadrant MW } \\
\hline Location & Small I-hole & Medium I & Large I & Small B & Large B \\
\hline $\begin{array}{c}\text { Bottom I fuel } \\
\text { section }\end{array}$ & $2.149 \mathrm{e}+00$ & $5.044 \mathrm{e}-01$ & $2.640 \mathrm{e}-01$ & $8.343 \mathrm{e}+00$ & $3.862 \mathrm{e}+00$ \\
\hline 2 & $2.455 \mathrm{e}+00$ & $6.336 \mathrm{e}-01$ & $3.073 \mathrm{e}-01$ & $9.942 \mathrm{e}+00$ & $4.486 \mathrm{e}+00$ \\
\hline 3 & $2.446 \mathrm{e}+00$ & $5.811 \mathrm{e}-01$ & $3.268 \mathrm{e}-01$ & $9.626 \mathrm{e}+00$ & $4.338 \mathrm{e}+00$ \\
\hline $\begin{array}{c}\text { Top 4 fuel } \\
\text { section }\end{array}$ & $1.982 \mathrm{e}+00$ & $4.947 \mathrm{e}-01$ & $2.495 \mathrm{e}-01$ & $7.532 \mathrm{e}+00$ & $3.490 \mathrm{e}+00$ \\
\hline SST cladding & $4.242 \mathrm{e}-02$ & $2.208 \mathrm{e}-02$ & $1.676 \mathrm{e}-02$ & $2.109 \mathrm{e}-01$ & $1.244 \mathrm{e}-01$ \\
\hline SST tube & $4.206 \mathrm{e}-02$ & $2.203 \mathrm{e}-02$ & $1.710 \mathrm{e}-02$ & $2.113 \mathrm{e}-01$ & $1.243 \mathrm{e}-01$ \\
\hline Water annulus & $6.356 \mathrm{e}-02$ & $3.130 \mathrm{e}-02$ & $2.368 \mathrm{e}-02$ & $4.652 \mathrm{e}-01$ & $2.147 \mathrm{e}-01$ \\
\hline Outer SST & $4.274 \mathrm{e}-02$ & $2.308 \mathrm{e}-02$ & $1.783 \mathrm{e}-02$ & $2.201 \mathrm{e}-01$ & $1.270 \mathrm{e}-01$ \\
\hline Outer water & $6.040 \mathrm{e}-02$ & $3.440 \mathrm{e}-02$ & $2.684 \mathrm{e}-02$ & $5.021 \mathrm{e}-01$ & $2.264 \mathrm{e}-01$ \\
\hline
\end{tabular}

For typical NE 30 MW cycle (110-B), the power split over NW, NE, Center, SW and SE lobes is $17,30,27,22$, and $29 \mathrm{MW}$, respectively. North-West quadrant $=23.75 \mathrm{MW}$, North-East quadrant $=36.75$, and East quadrant $=36.25 \mathrm{MW}$.

Fuel pellet diameter $=1.056 \mathrm{~cm}$, and density $=10.54 \mathrm{~g} / \mathrm{cc}$.

Table 21. Comparison of maximum linear power density and burnup ( $\mathrm{MWd} / \mathrm{MT})$ of weaponsgrade MOX fuel $\left(\mathrm{WGPuO}_{2} 5.0 \mathrm{wt} \%\right)$ capsules in the East quadrant of ATR* and a typical BWR $\mathrm{UO}_{2}$ fuel

\begin{tabular}{|c|c|c|c|c|}
\hline Location & $\begin{array}{c}\text { Specific power } \\
\text { (W/g) }\end{array}$ & $\begin{array}{c}\text { Max. linear } \\
\text { power density } \\
(\mathrm{kW} / \mathrm{ft})\end{array}$ & $\begin{array}{c}\text { Max. linear } \\
\text { power density } \\
(\mathrm{W} / \mathrm{cm})\end{array}$ & $\begin{array}{c}\text { Burnup } \\
\text { (MWD/MT) } \\
\text { per year }\end{array}$ \\
\hline BWR $^{*} \mathrm{UO}_{2}$ fuel & $4.767 \mathrm{e}+01$ & $1.341 \mathrm{e}+01$ & $4.400 \mathrm{e}+02$ & $1.430 \mathrm{e}+04$ \\
\hline \hline Small I & $9.334 \mathrm{e}+01$ & $2.627 \mathrm{e}+01$ & $8.616 \mathrm{e}+02$ & $3.074 \mathrm{e}+04$ \\
\hline Medium I & $2.209 \mathrm{e}+01$ & $6.215 \mathrm{e}+00$ & $2.039 \mathrm{e}+02$ & $7.273 \mathrm{e}+03$ \\
\hline Large I & $1.121 \mathrm{e}+01$ & $3.155 \mathrm{e}+00$ & $1.035 \mathrm{e}+02$ & $3.692 \mathrm{e}+03$ \\
\hline Small B & $3.641 \mathrm{e}+02$ & $1.025 \mathrm{e}+02$ & $3.361 \mathrm{e}+03$ & $1.199 \mathrm{e}+05$ \\
\hline Large B & $1.639 \mathrm{e}+02$ & $4.611 \mathrm{e}+01$ & $1.513 \mathrm{e}+03$ & $5.396 \mathrm{e}+04$ \\
\hline
\end{tabular}

* For typical NE $30 \mathrm{MW}$ cycle (110-B), the power split over NW, NE, Center, SW and SE lobes is $17,30,27,22$, and $29 \mathrm{MW}$, respectively. North-West quadrant $=23.75 \mathrm{MW}$, North-East quadrant $=36.75$, and East quadrant $=36.25 \mathrm{MW}$. The quarter core MCNP model is based on the middle of 110-B cycle fuel loading in the East quadrant with outer shim control drums at SE $85.40^{\circ}$ and NE $79.30^{\circ}$. There are 7 cycles per year at 42 effective full power days per cycle.

** Assume 300 full power days per year with thermal output $3579 \mathrm{MWt}$. 
Table 22. Total heat rates of $\mathrm{BWR}$ weapons-grade $\mathrm{MOX}$ fuel $\left(\mathrm{WGPuO}_{2} 7.0 \mathrm{wt} \%\right)$ capsules in small I, medium I, large I, small B, and large B-holes in the East quadrant of ATR

\begin{tabular}{|c|c|c|c|c|c|}
\cline { 2 - 6 } \multicolumn{1}{c|}{} & \multicolumn{5}{c|}{ Total heat rates (W/g) per quadrant MW } \\
\hline Location & Small I-hole & Medium I & Large I & Small B & Large B \\
\hline $\begin{array}{c}\text { Bottom 1 fuel } \\
\text { section }\end{array}$ & $2.556 \mathrm{e}+00$ & $6.267 \mathrm{e}-01$ & $3.336 \mathrm{e}-01$ & $9.932 \mathrm{e}+00$ & $4.453 \mathrm{e}+00$ \\
\hline 2 & $3.001 \mathrm{e}+00$ & $7.473 \mathrm{e}-01$ & $3.764 \mathrm{e}-01$ & $1.120 \mathrm{e}+01$ & $5.107 \mathrm{e}+00$ \\
\hline 3 & $2.758 \mathrm{e}+00$ & $6.878 \mathrm{e}-01$ & $3.834 \mathrm{e}-01$ & $1.069 \mathrm{e}+01$ & $4.912 \mathrm{e}+00$ \\
\hline $\begin{array}{c}\text { Top 4 fuel } \\
\text { section }\end{array}$ & $2.174 \mathrm{e}+00$ & $5.211 \mathrm{e}-01$ & $2.800 \mathrm{e}-01$ & $8.610 \mathrm{e}+00$ & $3.957 \mathrm{e}+00$ \\
\hline SST cladding & $4.534 \mathrm{e}-02$ & $2.264 \mathrm{e}-02$ & $1.711 \mathrm{e}-02$ & $2.143 \mathrm{e}-01$ & $1.262 \mathrm{e}-01$ \\
\hline SST tube & $4.361 \mathrm{e}-02$ & $2.286 \mathrm{e}-02$ & $1.720 \mathrm{e}-02$ & $2.153 \mathrm{e}-01$ & $1.250 \mathrm{e}-01$ \\
\hline Water annulus & $6.783 \mathrm{e}-02$ & $3.355 \mathrm{e}-02$ & $2.437 \mathrm{e}-02$ & $4.773 \mathrm{e}-01$ & $2.199 \mathrm{e}-01$ \\
\hline Outer SST & $4.410 \mathrm{e}-02$ & $2.360 \mathrm{e}-02$ & $1.820 \mathrm{e}-02$ & $2.250 \mathrm{e}-01$ & $1.273 \mathrm{e}-01$ \\
\hline Outer water & $6.336 \mathrm{e}-02$ & $3.589 \mathrm{e}-02$ & $2.769 \mathrm{e}-02$ & $5.100 \mathrm{e}-01$ & $2.290 \mathrm{e}-01$ \\
\hline
\end{tabular}

For typical NE $30 \mathrm{MW}$ cycle (110-B), the power split over NW, NE, Center, SW and SE lobes is $17,30,27,22$, and $29 \mathrm{MW}$, respectively. North-West quadrant $=23.75 \mathrm{MW}$, North-East quadrant $=36.75$, and East quadrant $=36.25 \mathrm{MW}$.

Fuel pellet diameter $=1.056 \mathrm{~cm}$, and density $=10.54 \mathrm{~g} / \mathrm{cc}$.

Table 23. Comparison of maximum linear power density and burnup (MWd/MT) of weaponsgrade MOX fuel (WGPuO $27.0 \mathrm{wt} \%$ ) capsules in the East quadrant of ATR* and a typical BWR $\mathrm{UO}_{2}$ fuel

\begin{tabular}{|c|c|c|c|c|}
\hline Location & $\begin{array}{c}\text { Specific power } \\
(\mathrm{W} / \mathrm{g})\end{array}$ & $\begin{array}{c}\text { Max. linear } \\
\text { power density } \\
(\mathrm{kW} / \mathrm{ft})\end{array}$ & $\begin{array}{c}\text { Max. linear } \\
\text { power density } \\
(\mathrm{W} / \mathrm{cm})\end{array}$ & $\begin{array}{c}\text { Burnup } \\
\text { (MWD/MT) } \\
\text { per year }\end{array}$ \\
\hline BWR $^{*} \mathrm{UO}_{2}$ fuel & $4.767 \mathrm{e}+01$ & $1.341 \mathrm{e}+01$ & $4.400 \mathrm{e}+02$ & $1.430 \mathrm{e}+04$ \\
\hline \hline Small I & $1.088 \mathrm{e}+02$ & $3.062 \mathrm{e}+01$ & $1.004 \mathrm{e}+03$ & $3.582 \mathrm{e}+04$ \\
\hline Medium I & $2.609 \mathrm{e}+01$ & $7.342 \mathrm{e}+00$ & $2.409 \mathrm{e}+02$ & $8.592 \mathrm{e}+03$ \\
\hline Large I & $1.349 \mathrm{e}+01$ & $3.795 \mathrm{e}+00$ & $1.245 \mathrm{e}+02$ & $4.441 \mathrm{e}+03$ \\
\hline Small B & $4.153 \mathrm{e}+02$ & $1.169 \mathrm{e}+02$ & $3.834 \mathrm{e}+03$ & $1.368 \mathrm{e}+05$ \\
\hline Large B & $1.876 \mathrm{e}+02$ & $5.280 \mathrm{e}+01$ & $1.732 \mathrm{e}+03$ & $6.178 \mathrm{e}+04$ \\
\hline
\end{tabular}

* For typical NE 30 MW cycle (110-B), the power split over NW, NE, Center, SW and SE lobes is $17,30,27,22$, and $29 \mathrm{MW}$, respectively. North-West quadrant $=23.75 \mathrm{MW}$, North-East quadrant $=36.75$, and East quadrant $=36.25 \mathrm{MW}$. The quarter core MCNP model is based on the middle of 110-B cycle fuel loading in the East quadrant with outer shim control drums at SE $85.40^{\circ}$ and NE $79.30^{\circ}$. There are 7 cycles per year at 42 effective full power days per cycle.

* Assume 300 full power days per year with thermal output $3579 \mathrm{MWt}$. 
Figures 10-13 show the residual radioactivity and the residual decay heat in drop-in capsules containing PWR and BWR MOX pellets at an enrichment of 5\%, after the pins are removed from the reactor following irradiation in a small I-hole for a long enough time to achieve a burnup of $45,000 \mathrm{MWd} / \mathrm{MT}$. In all cases, the activity drops by about a factor of five and the decay heat drops by about a factor of ten within a day. These quantities fall by a further factor of three or four within about three weeks and then subside slowly.

Tables 24 and 25, for PWR and BWR MOX fuel capsules, respectively, show the maximum temperatures attained in the fuel pellets in each of the I-holes for which the neutronics calculations of this section were performed. These temperatures were obtained by using the heat rates predicted by the neutronics calculations as input to the ABAQUS thermohydraulics code, ${ }^{28}$ with appropriate ATR coolant conditions as the thermohydraulic environment: the inlet temperature was $125^{\circ} \mathrm{F}$, the mass flow rate was $8.3151 \mathrm{bm} / \mathrm{in}^{2}$-s , and the inlet pressure was 355 psia.

Each of the tables shows results for two capsule configurations - the single-encapsulation and double-encapsulation configurations shown in Figure 4. For each configuration, the temperatures are given in the tables for the small, medium, and large I-holes and for MOX fuel compositions of $3.0,5.0$, and $7.0 \mathrm{wt} \% \mathrm{WGPuO}_{2}$.

The results in the tables confirm some relationships that one would expect from basic physical principles. Singly encapsulated fuel runs cooler than doubly encapsulated fuel for the same linear heat rate. Higher $\mathrm{WGPuO}_{2}$ concentrations raise the operating temperatures in a given reactor power configuration. Because PWR pellets have smaller diameter, they run cooler than $B W R$ pellets in a given reactor power configuration.

Other trends, which the tables do not contain enough data to illustrate, can also be stated. Reducing the thickness of the gap between the fuel pellets and the cladding improves heat transfer out of the pellets and reduces fuel temperatures. Since the ratio of axial maximum thermal neutron flux to axial minimum thermal neutron flux in the ATR is approximately 2 , substantial reductions in maximum temperatures can be achieved by shifting the axial placement of short capsules towards the lower-flux end regions. (Capsules with fueled regions longer than half the length of the core obviously cannot be shifted far enough to avoid the peak flux location, but if the downstream end of the capsule is placed near this location, the coolant temperature will be low where the heat generation rate is highest, and fuel temperatures may still remain below the melting point.) 


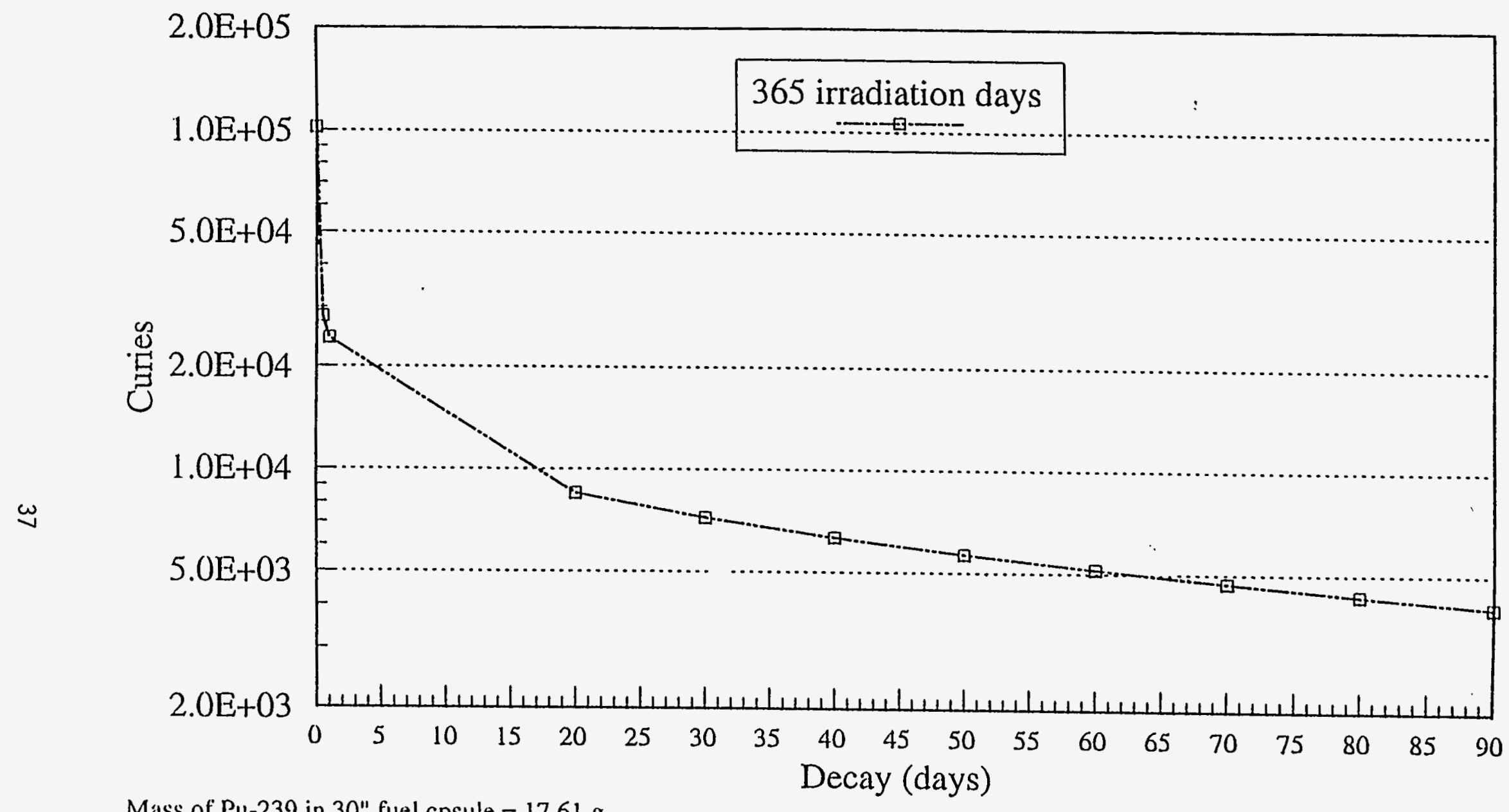

Mass of Pu-239 in 30" fuel cpsule $=17.61 \mathrm{~g}$

Weapons-grade Pu 5 wi\%.

Figure 10. Radioactivity of actinides and fission products in PWR MOX fuel capsule irradiated in small I-hole. 


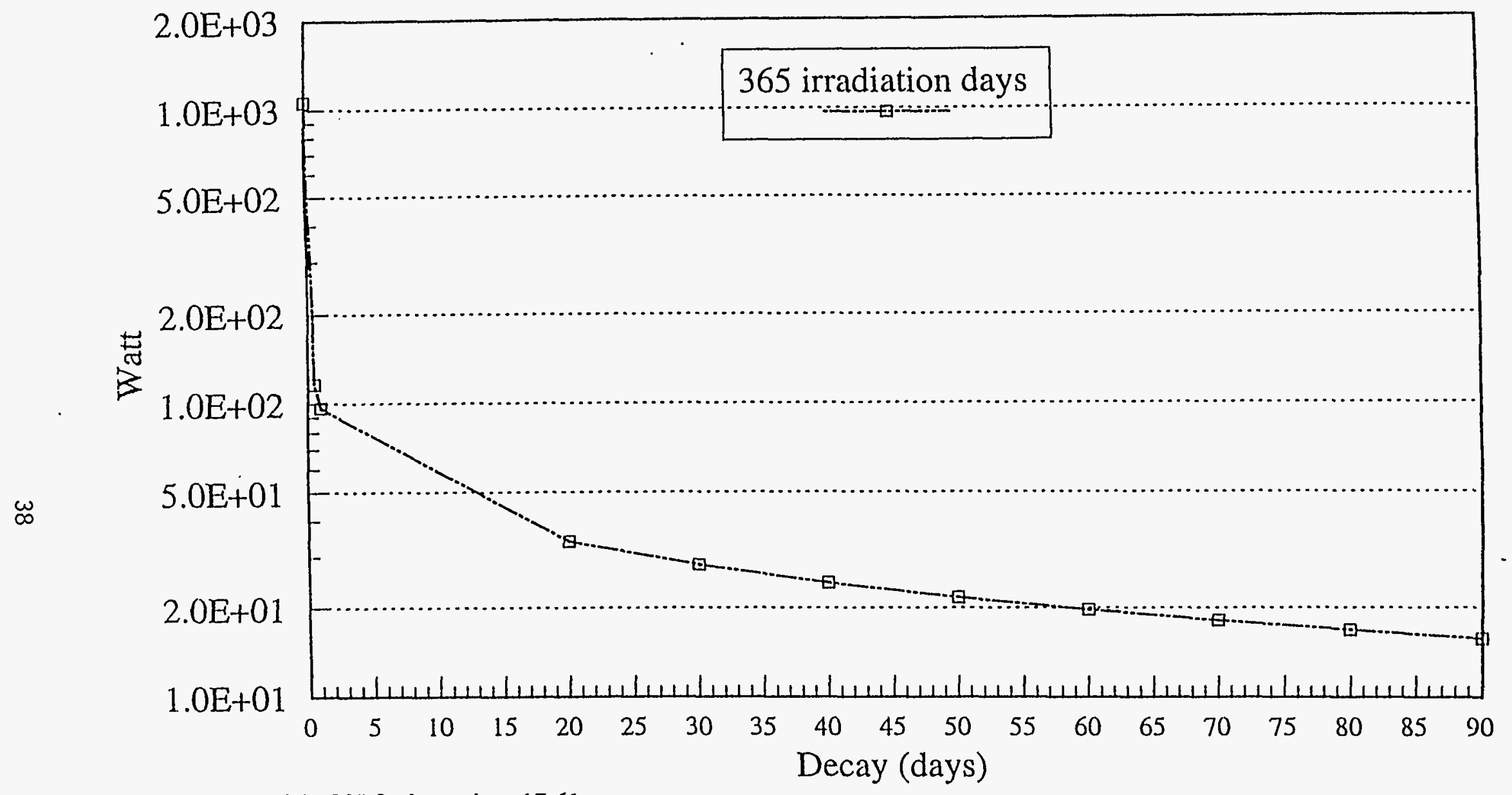

Mass of Pu-239 in 30" fuel cpsule $=17.61 \mathrm{~g}$

Weapons-grade Pu 5 wt\%.

Figure 11. Thermal heat of actinides and fission products in PWR MOX fuel capsule irradiated in small I-hole. 


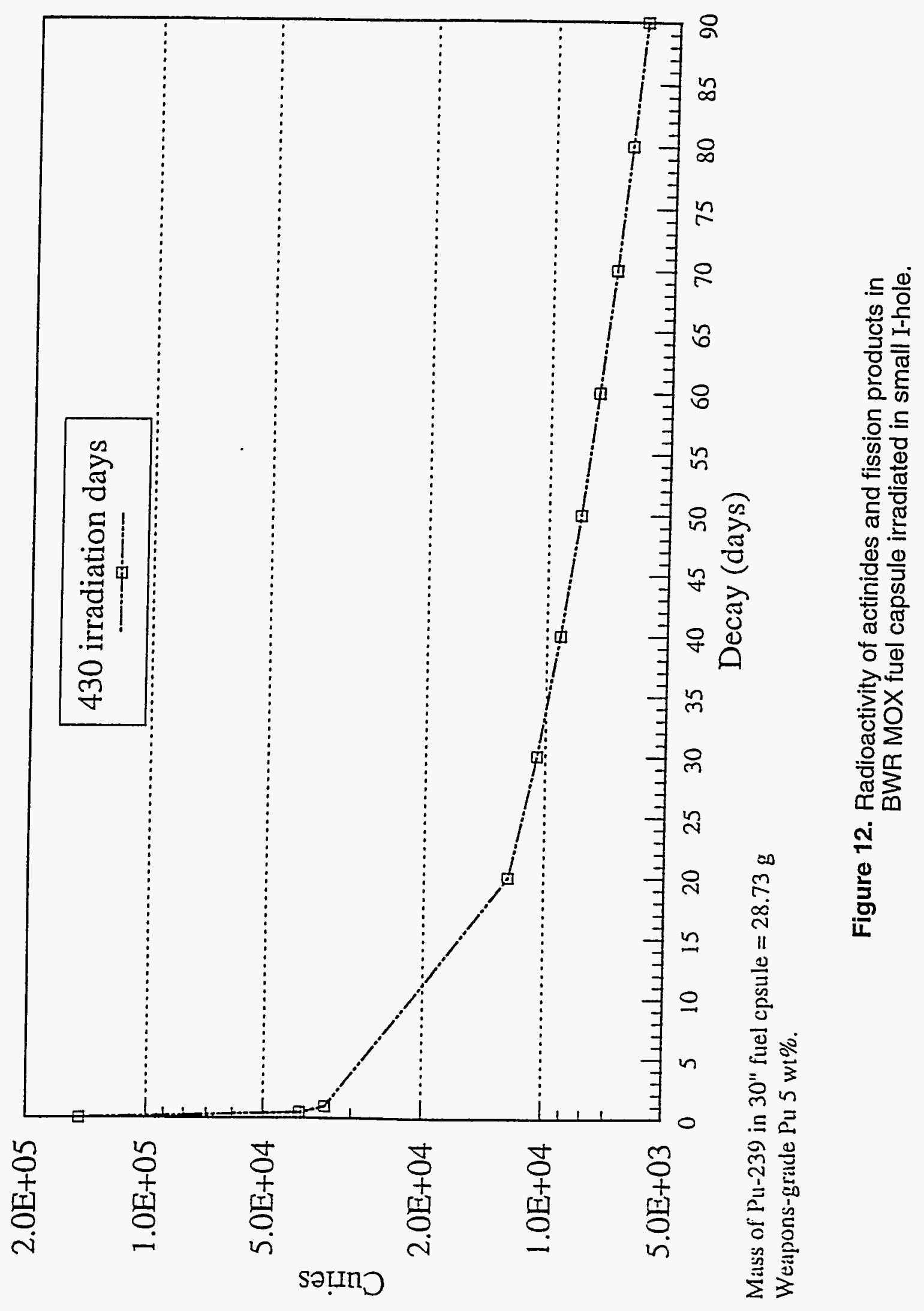




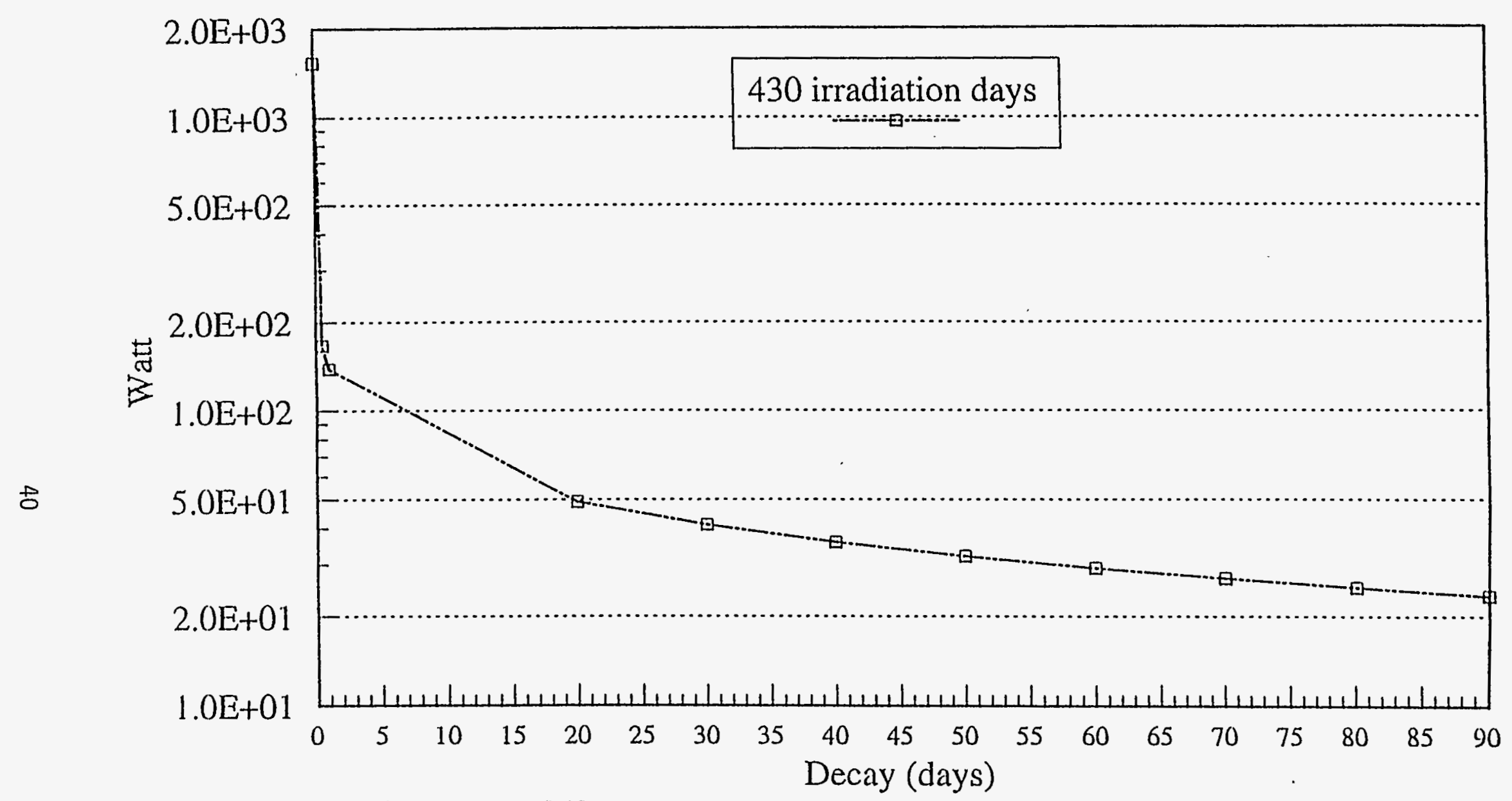

Mass of Pu-239 in 30" fuel cpsule $=28.73 \mathrm{~g}$

Weapons-grade Pu 5 wi\%.

Figure 13. Thermal heat of actinides and fission products in BWR MOX fuel capsule irradiated in small I-hole. 
Table 24. Maximum Temperatures for PWR MOX Fuel in ATR I-Holes

\begin{tabular}{|c|c|c|c|c|c|}
\hline & & & \multicolumn{3}{|c|}{ Temperature, ${ }^{\circ} \mathrm{C}$} \\
\hline Location & $\begin{array}{c}\text { Configuration and gas } \\
\text { gap(s) (in.) }\end{array}$ & $\mathrm{GaS}$ & $\mathrm{Wt \%} \mathrm{PuO}_{2}$ & $\mathrm{Wt} \% \mathrm{PuO}_{2}$ & $\mathrm{Wt \%} \mathrm{PuO}_{2}$ \\
\hline & & & & & \\
\hline & & & 3 & 5 & 7 \\
\hline Small I & Double, .003 and .007 & $\mathrm{Ne}, \mathrm{He}$ & 2886 & 3344 & 3899 \\
\hline Medium 1 & Double, .003 and .007 & $\mathrm{Ne}, \mathrm{He}$ & 958 & 1211 & 1359 \\
\hline Large I & Double, .003 and .007 & $\mathrm{Ne}, \mathrm{He}$ & 604 & 733 & 824 \\
\hline & & & & & \\
\hline Small I & Single, .002 & $\mathrm{Ne}$ & 2368 & 2809 & 3348 \\
\hline Medium I & Single, .002 & $\mathrm{Ne}$ & 585 & 783 & 908 \\
\hline Large I & Single, .002 & $\mathrm{Ne}$ & 361 & 439 & 506 \\
\hline
\end{tabular}

Table 25. Maximum Temperatures for BWR MOX Fuel in ATR I-holes

\begin{tabular}{|c|c|c|c|c|c|}
\hline & & & \multicolumn{3}{|c|}{ Temperature, ${ }^{\circ} \mathrm{C}$} \\
\hline Location & $\begin{array}{c}\text { Configuration and gas } \\
\text { gap(s) (in.) }\end{array}$ & $\mathrm{Gas}$ & $\mathrm{Wt \%} \mathrm{PuO}_{2}$ & Wt\% $\mathrm{PuO}_{2}$ & $\mathrm{Wt} \mathrm{PuO}_{2}$ \\
\hline & & & 3 & 5 & 7 \\
\hline Small I & Double, .003 and .007 & $\mathrm{Ne}, \mathrm{He}$ & 3515 & 4152 & \\
\hline Medium I & Double, .003 and .007 & $\mathrm{Ne}, \mathrm{He}$ & 1169 & 1498 & 1700 \\
\hline Large I & Double, .003 and .007 & $\mathrm{Ne}, \mathrm{He}$ & 704 & 857 & 996 \\
\hline & & & & & \\
\hline Small I & Single, .002 & $\mathrm{Ne}$ & 2904 & 3521 & 4139 \\
\hline Medium I & Single, .002 & $\mathrm{Ne}$ & 731 & 998 & 1189 \\
\hline Large I & Single, .002 & $\mathrm{Ne}$ & 414 & 511 & 602 \\
\hline
\end{tabular}

For the configurations shown in Figure 4, maximum fuel temperatures in the small I-hole approach or exceed the MOX fuel melting point of approximately $2500^{\circ} \mathrm{C}$ except for the singly encapsulated PWR pellets at the $3.0 \mathrm{wt} \% \mathrm{WGPuO}_{2}$ composition. In the other I-holes, the maximum fuel temperatures remain well below the melting point. For placement in ATR small Iholes, except for PWR pellets at $3.0 \mathrm{wt} \% \mathrm{WGPuO}_{2}$, one or more of several possible steps could be taken. First, a shroud of hafnium, which is a very strong absorber of thermal neutrons, could be placed around the capsule. This step is a standard method of reducing thermal neutron fluxes in ATR experiment locations, and the proper amount of hafnium shrouding could allow burnup rates, etc., to be higher than those attainable in the medium or large I-holes without causing the fuel to melt. Second, capsules could be placed in small I-holes in ATR quadrants operating at lower power than the East quadrant for which the analyses were performed (as noted above and in the tables, the East side of the reactor is expected to operate at about $50 \%$ higher power than the West 
side in typical future cycles). Third, the gap between the fuel and the cladding can be reduced. Fourth, short capsules, located near the ends of the core, can be used.

Thermohydraulics calculations were also performed for unshrouded capsules in the small and large B-holes, but the temperatures were so high that it is not useful to report them.

\subsection{EMOX Fuel}

Only a small effort was devoted to neutronics calculations for EMOX fuel pellets. These calculations considered a short fuel capsule as shown in Figure 3, placed in small, medium, and large I-holes in the Northwest quadrant of the ATR. Table 26 gives the total heat rates for these capsules. Figures 14 and 15 show the residual radioactivity and the residual decay heat in the capsule that was irradiated in the small I-hole, after its removal from the reactor.

Table 26. Total heat rates of the evolutionary weapons-grade MOX fuel (WGPuO $4.0 \mathrm{wt} \%)^{\mathrm{A}}$ capsules in small I, medium I, and large I-holes in the North-West quadrant of ATR

\begin{tabular}{|c|c|c|c|}
\hline & \multicolumn{3}{|c|}{ Total heat rates (w/g per quadrant MW) } \\
\hline ID & Small I-hole & Medium I-hole & Large I-hole \\
\hline Top I fuel section ${ }^{3}$ & $3.350 \mathrm{e}+00$ & $1.177 \mathrm{e}+00$ & $7.226 \mathrm{e}-01$ \\
\hline 2 & $3.641 e+00$ & $1.350 \mathrm{e}+00$ & $8.433 \mathrm{e}-01$ \\
\hline 3 & $3.486 \mathrm{e}+00$ & $1.249 \mathrm{e}+00$ & $7.541 \mathrm{e}-01$ \\
\hline Bottom 4 fuel section & $2.753 e+00$ & $9.611 \mathrm{e}-01$ & $5.908 \mathrm{e}-01$ \\
\hline SST cladding & $5.136 e-02$ & $2.813 e-02$ & $2.196 \mathrm{e}-02$ \\
\hline SST tube & $4.978 \mathrm{e}-02$ & $2.819 e-02$ & $2.181 \mathrm{e}-02$ \\
\hline Water annulus & $6.742 \mathrm{e}-02$ & $3.743 \mathrm{e}-02$ & $2.812 \mathrm{e}-02$ \\
\hline Outer SST & $4.967 e-02$ & $2.864 \mathrm{e}-02$ & $2.276 \mathrm{e}-02$ \\
\hline Outer water & $6.115 \mathrm{e}-02$ & $3.821 \mathrm{e}-02$ & $4.318 \mathrm{e}-01$ \\
\hline
\end{tabular}

A EMOX composition: $\mathrm{PuO}_{2} 4.0 \mathrm{wt} \%, \mathrm{UO}_{2} 66.0 \mathrm{wt} \%, \mathrm{ZrO}_{2} 26.4 \mathrm{wt} \%$, and $\mathrm{CaO} 3.6 \mathrm{wt} \%$.

For typical NE $30 \mathrm{MW}$ cycle, the power split over NW, NE, Center, SW and SE lobes is 17, 30, $25.9,26$, and $27 \mathrm{MW}$, respectively. North-West quadrant $=23.48 \mathrm{MW}$, North-East quadrant 36.48 , and East quadrant $=34.98 \mathrm{MW}$. 


\section{Figure 14: Radioactivity of actinides and fission products in 20 irradiated EMOX fuel pellets}

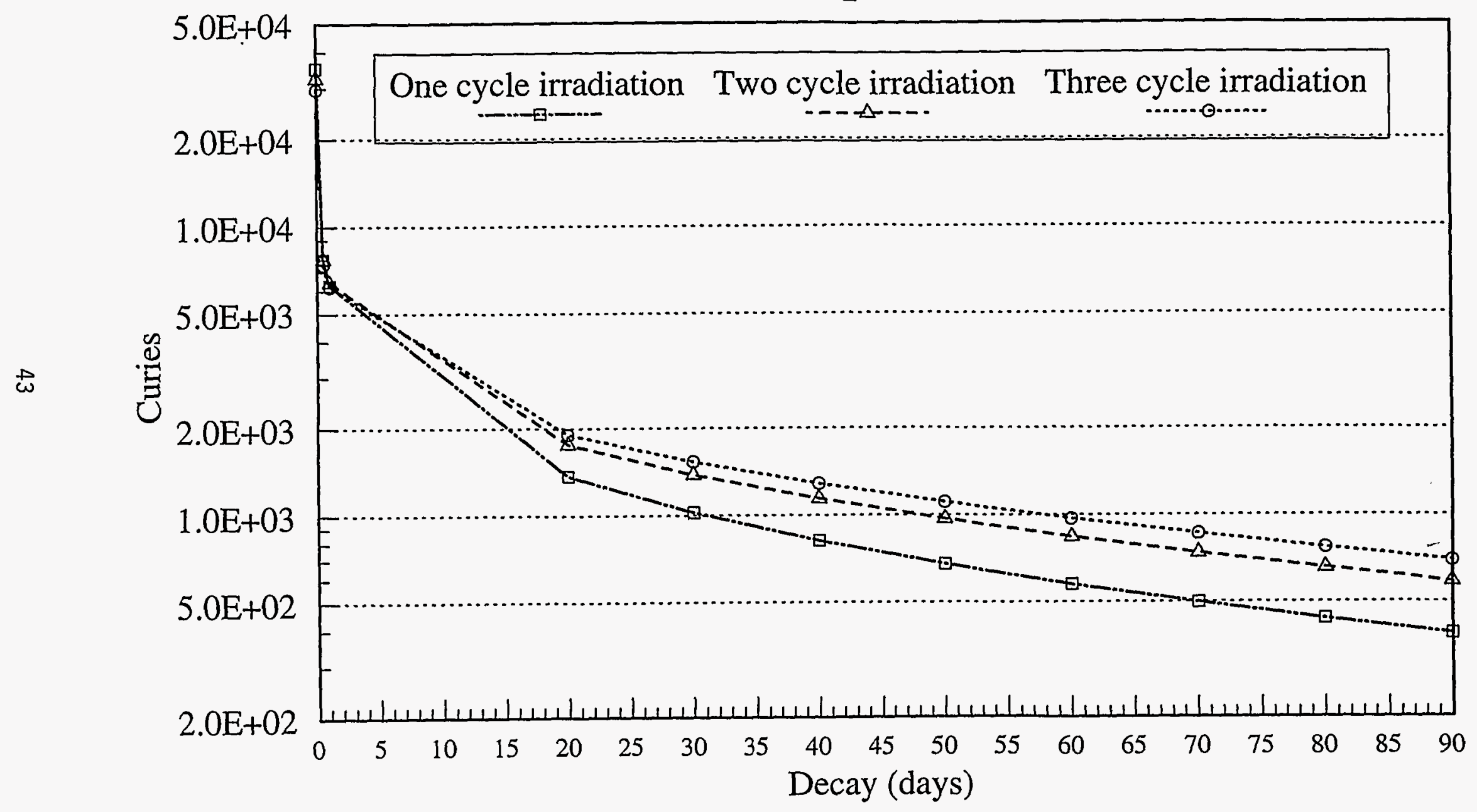

Mass of Pu-239 in 20 fuel pellets $=3.68 \mathrm{~g}$ 


\section{Figure 15: Thermal heat of actinides and fission products in 20 irradiated EMOX fuel pellets}

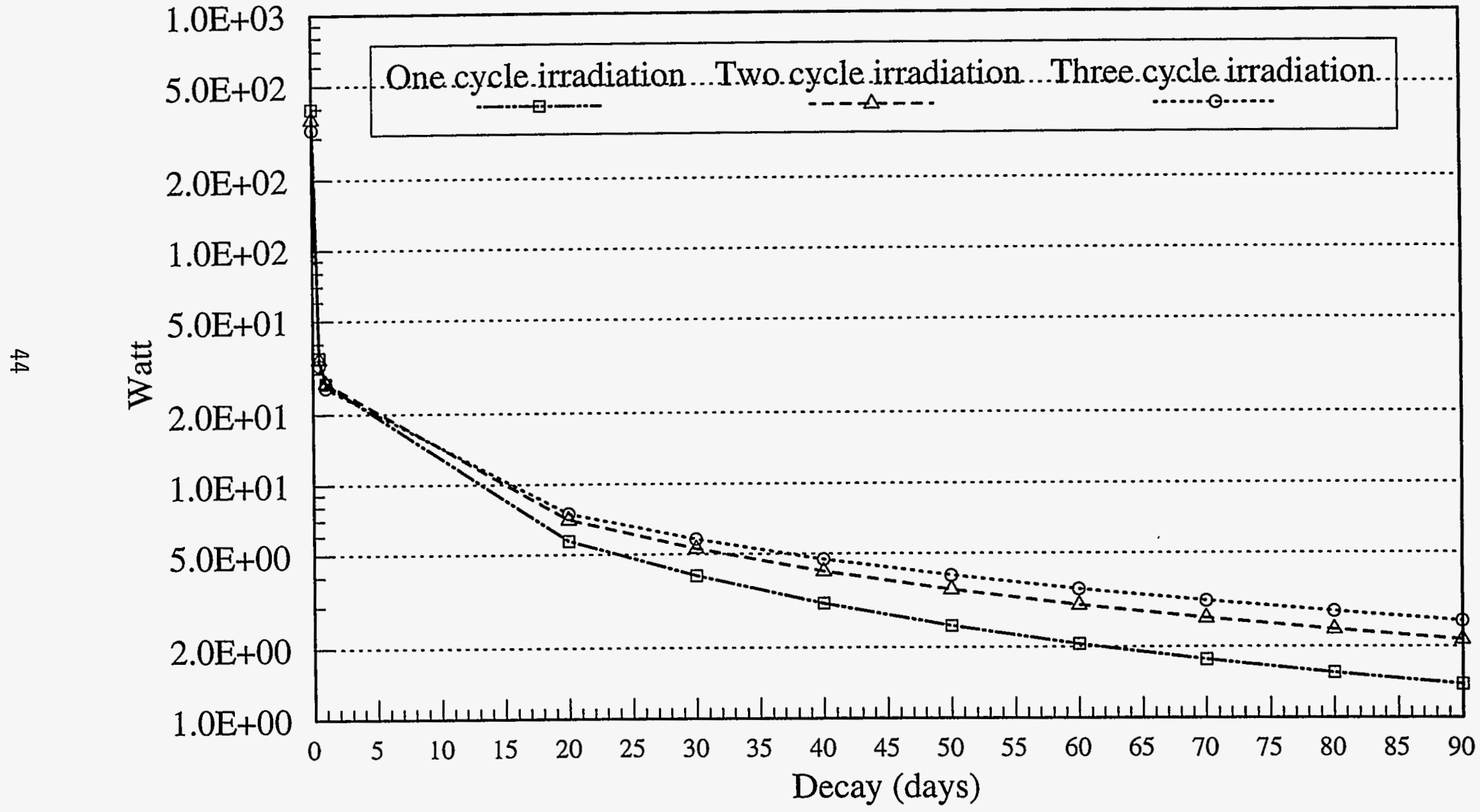

Mass of Pu-239 in 20 fuel pellets $=3.68 \mathrm{~g}$ 


\subsection{NEUTRONICS ANALYSIS OF COMMERCIAL REACTORS}

During the course of this LDRD project we received questions from potential ATR customers about how ATR parameters (neutron fluxes, neutron spectra, linear heat generation rates, and MOX burnup rates) compare with commercial reactor parameters. So, we decided to establish a capability to analyze commercial Pressurized Water Reactors (PWR), Boiling Water Reactors (BWR), and Canadian Deuterium-Uranium (CANDU) reactors. Furthermore, we desired to have a neutronics methodology that is consistent with the methodology used to analyze the ATR. This should avoid potential questions that could arise if one method such as modal theory with only a few neutron energy groups were used to analyze commercial reactors, and a different method such as continuous-energy Monte Carlo were used to analyze the ATR. Now, we have established the capability to analyze all reactors using the same consistent and reasonably accurate method.

Sections 6.1 through 6.5 describe a mixed $\mathrm{UO}_{2}$ and WG-MOX fuel assembly in a checkerboard arrangement within a PWR. The codes MCNP, ${ }^{26}$ ORIGEN, ${ }^{29}$ and a new checkerboard mixed fuel assembly model depletion tool were used to analyze the WG-MOX fuel burnup characteristics. The fuel assembly physics and burnup characteristics are analyzed, and the results are discussed. WG-MOX fuel assembly design features and the unit cell and checkerboard models are described in Sections 6.1 and 6.2. A unit pin cell model was used to analyze the $\mathrm{UO}_{2}$ and WG-MOX fuel lattices as described in Section 6.3. In that section, the relationship between the infinite core multiplication factor $\mathrm{K}_{\infty}$ and the pin pitch for the $\mathrm{UO}_{2}$ and WG-MOX fuel lattices is discussed. The plutonium transmutation characteristics of a proposed mixed pressurized water reactor core were investigated using the checkerboard MCNP model and the ORIGEN2 computer code. In Section 6.4 the calculated neutronics characteristics $\left(\mathrm{K}_{\infty}\right.$ and relative pin power distribution) of the mixed $\mathrm{UO}_{2}$ and WG-MOX fuel assembly are compared to a low-enriched $\mathrm{UO}_{2}$ fuel assembly, and the calculated burnup characteristics in a mixed PWR core are also discussed. Section 6.5 summarizes the PWR analyses. Section 6.6 describes the BWR and CANDU models. Section 6.7 presents comparisons of neutron flux spectra in the various reactors.

\subsection{Weapons-Grade MOX Fuel Assembly Design Features}

In order for the well-established operating experience and neutronics safety features of lowenriched $\mathrm{UO}_{2}$ in LWRs to be preserved, the WG-MOX fuel should be compatible with commercial PWR design. The assembly configuration of a Westinghouse PWR ( $17 \times 17$ fuel element array) should be retained so that the maximum use of current LWR technology can be made. Because 
${ }^{239} \mathrm{Pu}$ has a higher thermal neutron absorption cross section than ${ }^{235} \mathrm{U}$, the neutron spectrum in MOX fuel is hardened, and the boron worth is reduced. The impact of WG-MOX fuel in the PWR core will be reduced by interspersing the WG-MOX fuel assemblies with PWR $\mathrm{UO}_{2}$ fuel assemblies in a checkerboard arrangement as shown in Figure 16. Another advantage of mixing $\mathrm{UO}_{2}$ and WG-MOX fuel assemblies is that the difference in delayed neutron parameters of WGMOX and conventional $\mathrm{UO}_{2}$ fuel will be reduced. The discharged WG-MOX spent fuel should have a ${ }^{240} \mathrm{Pu} / \mathrm{Pu}$ ratio $>24 \%$, about the same as for the $\mathrm{LWR} \mathrm{UO}_{2}$ spent fuel.

Another important design requirement to meet is that the WG-MOX fuel relative pin power cannot exceed the limiting value. The limiting relative fuel pin power in a typical PWR core is 1.52. ${ }^{30}$ By definition, the peak relative pin power in the core is the product of the peak relative assembly power and the peak relative pin power (PRPP) in an assembly. At the beginning of cycle (BOC), the peak relative assembly power is $1.22 .^{31}$ In general, the peak of relative assembly power will decrease toward the end of cycle (EOC), while the PRPP remains relatively constant during the fuel cycle. So the advanced WG-MOX fuel assembly should be optimized to guarantee that the PRPP is less than the limiting value $1.52 / 1.22=1.245$ at BOC.

For this study, the design goals of the mixed $\mathrm{UO}_{2}$ and WG-MOX fuel assembly are: (1) to use a current PWR $17 \times 17$ fuel-element assembly geometry, (2) to provide adequate excess reactivity for fuel depletion, (3) to meet the spent fuel standard, (4) to assure a negative temperature coefficient, and (5) to keep the PRPP less than 1.245 at the BOC.

\subsection{Unit Cell and Checkerboard Assembly Models}

In general, reactor physics analysis consists of multistep analysis methods. The successive steps are pin-cell, fuel assembly, and reactor core analyses. The multidimensional, multigroup diffusion equation with node-wise constant cross sections requires the heterogeneous structure in the fuel assembly to be appropriately homogenized. The resulting homogeneous power distribution can be combined with a suitable dehomogenization technique to reconstruct the pinwise power distribution. However, the complex spectral transitions at the boundaries between $\mathrm{UO}_{2}$ and WG-MOX fuel assemblies present a serious challenge. A checkerboard fuel assembly model (CBFAM), which will eliminate the generation of few-group cross sections and the homogenization and dehomogenization steps, is introduced to accomplish the new mixed-fuel analysis in one comprehensive step. ${ }^{32}$ The CBFAM can perform the calculation in a straightforward fashion and treat the entire mixed assembly at once. Its disadvantages are a longer computational time to achieve the required tally precision, and statistical fluctuations in the results. 


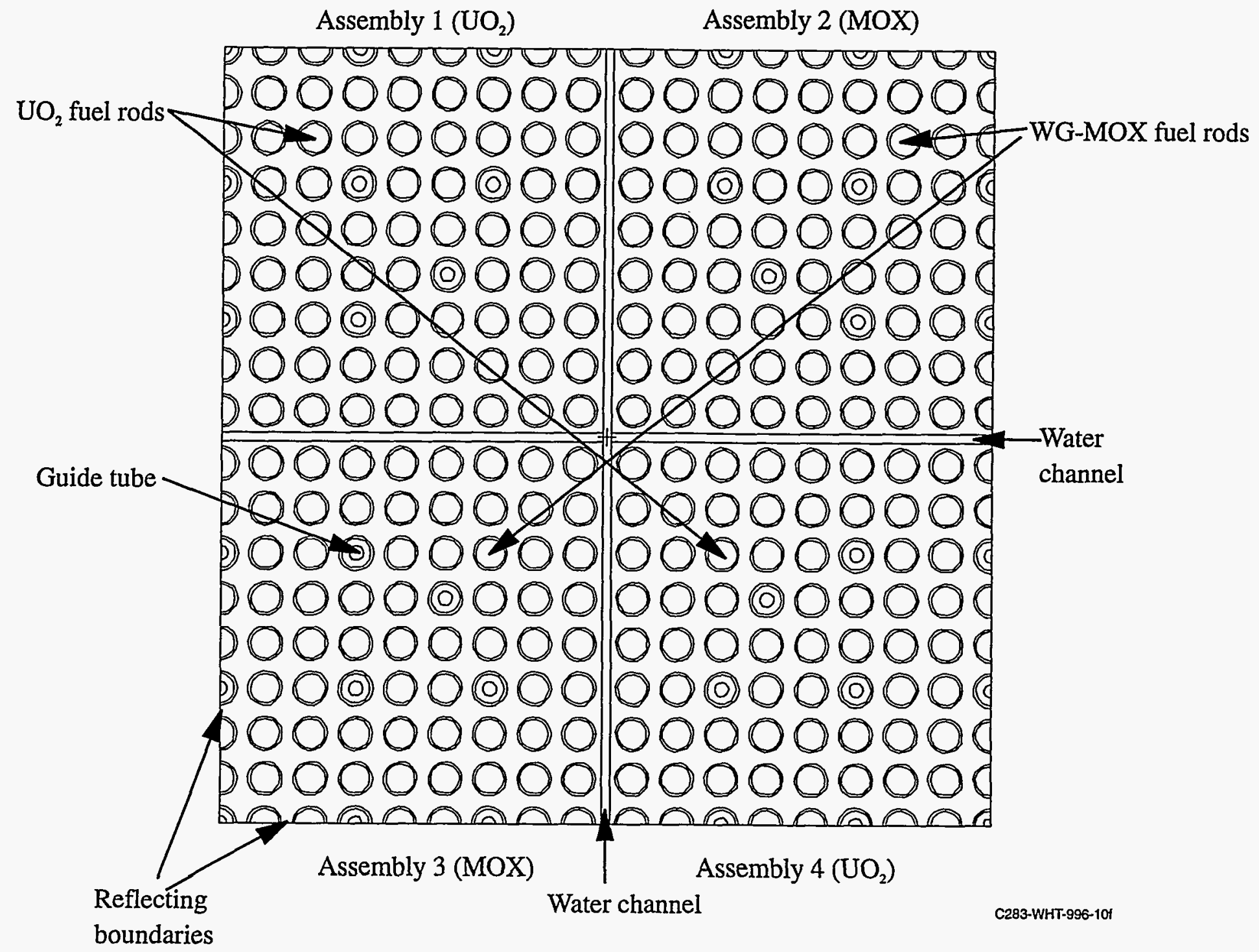

Figure 16. Plan view of an MCNP model of one quarter of four $17 \times 17$ element PWR fuel assemblies with reflective planes on a $21.5 \mathrm{~cm}$ square lattice. 
A typical PWR unit cell has been chosen as the basic unit cell configuration for the fuel neutronic analysis. The unit cell consists of one fuel pin and a one-pitch square of surrounding water. $\mathrm{UO}_{2}$ and WG-MOX with $96 \%$ of theoretical density were used in the fuel compositions. The fuel pins are $0.819 \mathrm{~cm}$ in diameter; they are clad with $0.0527 \mathrm{~cm}$ of $\mathrm{Zr}$. A gap of $0.0082 \mathrm{~cm}$ separates the $\mathrm{UO}_{2}$ pin from the clad tube. The moderator water density in the hot condition is $0.727 \mathrm{~g} / \mathrm{cm}^{3}$.

The codes MCNP and ORIGEN2 are used with a new CBFAM depletion tool to analyze the mixed $\mathrm{UO}_{2}$ and WG-MOX fuel assembly burnup characteristics. MCNP is a 3-dimensional, continuous-energy, coupled neutron-photon transport code. It utilizes pointwise cross-section data evaluated from ENDF/B-V (and/or ENDF/B-VI). Both the free gas and $S(\alpha, \beta)$ models are used to describe thermal neutron scattering. The MCNP-calculated fluxes and neutron reaction rates within each unit cell for neutrons in the energy range from 0 to $20 \mathrm{MeV}$ are normalized to a one group flux and burnup-dependent one-group cross sections (BDOGXS), which are then input to ORIGEN2 isotope buildup and depletion calculations. ${ }^{33}$ Following the ORIGEN2 calculations (one ORIGEN2 run per cell), the calculated isotopic concentrations in each cell are transferred back to the MCNP model for the next static calculation. Throughout the fuel depletion process, the data conversion between the two codes is handled by a UNIX shell script and the Lotus 1-2-3 spreadsheet macro code. ${ }^{34}$ Because the cross sections of ${ }^{235,238} \mathrm{U}$ and ${ }^{239-242} \mathrm{Pu}$ do not vary linearly with burnup, ${ }^{35}$ the on-line cross-section corrections as described above are used in the mixed fuel assembly burnup analysis. The methodology developed in this study can also be applied in design analyses for WG-MOX fuel testing in the Advanced Test Reactor and for WG-MOX fuel lead test assemblies in PWR cores. A similar methodology using MCNP and ORIGEN2, developed at the INEL, shows excellent results when compared to the CASMO code, which is used for LWR assembly calculations. ${ }^{20,21}$

\subsection{Unit Cell and Fuel Assembly Neutronic Characteristics}

Using the unit cell model, evaluations of the relationship between the MCNP-calculated infinite multiplication factor and pin pitch were carried out for $\mathrm{UO}_{2}$ and $\mathrm{WG}-\mathrm{MOX}$ fuel lattices. The fuel compositions of the four study cases are tabulated in Table 27. The uranium in cases 1 and 2 contains 3.2 and 5.0 atom \% of ${ }^{235} \mathrm{U}$. The ${ }^{238} \mathrm{Pu},{ }^{239} \mathrm{Pu},{ }^{240} \mathrm{Pu},{ }^{241} \mathrm{Pu}$, and ${ }^{242} \mathrm{Pu}$ atom percents of the $\mathrm{Pu}$ in WG-MOX fuel are $0.045,93.6,5.9,0.4$ and 0.1 , respectively. The weight percents of $\mathrm{WGPuO}_{2}$ in cases 3 and 4 are 3.5 and $5.0 \mathrm{wt} \%$. The MCNP-calculated $\mathrm{K}_{\infty}$ values $( \pm$ 0.0014) for these four cases are plotted in Figure 17 as functions of pitch. 
Table 27. Fuel compositions of $\mathrm{UO}_{2}$ and WG-MOX PWR fuel pins in unit cells and the mixed fuel assembly.

\begin{tabular}{|c|c|c|c|}
\hline $\mathrm{ID}$ & $\mathrm{UO}_{2}$ unit cell & \multicolumn{2}{|c|}{ WG-MOX unit cell } \\
\hline Case 1 & $\mathrm{UO}_{2}{ }^{235} \mathrm{U} 3.2$ atom\% & & \\
\hline Case 2 & & \multicolumn{2}{|c|}{$\begin{array}{c}\text { Weapons-grade } \mathrm{PuO}_{2} 3.5 \mathrm{wt} \% \\
\text { Depleted } \mathrm{UO}_{2} \text { with }{ }^{235} \mathrm{U} 0.2 \text { atom\% }\end{array}$} \\
\hline Case 3 & $\mathrm{UO}_{2}{ }^{235} \mathrm{U} 5.0$ atom $\%$ & & \\
\hline Case 4 & & \multicolumn{2}{|c|}{$\begin{array}{c}\text { Weapons-grade } \mathrm{PuO}_{2} 5.0 \mathrm{wt} \% \\
\text { Depleted } \mathrm{UO}_{2} \text { with }{ }^{235} \mathrm{U} 0.2 \text { atom\% }\end{array}$} \\
\hline $\begin{array}{l}\text { Mixed } \mathrm{UO}_{2} \text { and WG- } \\
\text { MOX fuel assembly }\end{array}$ & Assembly $1^{\mathrm{a}}$ and 4 & \multicolumn{2}{|c|}{ Assembly 2 and 3} \\
\hline Checkerboard 1 & $\mathrm{UO}_{2}{ }^{233} \mathrm{U} 3.2$ atom\% & \multicolumn{2}{|c|}{$\overline{\mathrm{UO}_{2}}$} \\
\hline Checkerboard 2 & $\mathrm{UO}_{2}{ }^{235} \mathrm{U} 3.2$ atom\% & \multicolumn{2}{|c|}{ Weapons-grade $\mathrm{PuO}_{2} 3.5 \mathrm{wt} \%$} \\
\hline \multirow[t]{2}{*}{$\begin{array}{l}\text { Checkerboard 3 } \\
\text { (Optimized }\end{array}$} & \multirow[t]{2}{*}{$\mathrm{UO}_{2}{ }^{235} \mathrm{U} 3.2$ atom $\%$} & Assembly 2 & Assembly 3 \\
\hline & & $\begin{array}{c}\text { Weapons-grade } \mathrm{PuO}_{2} \\
2.0 \text { wt\% at }(1,1)^{\mathrm{b}} \text {, } \\
(2,1) \text {, and }(1,9) \text { corner } \\
\text { rod positions } \\
\text { Weapons-grade } \mathrm{PuO}_{2} \\
2.5 \text { wt\% at }(1,2 \text { to } 8), \\
\text { and ( } 2 \text { to } 9,9) \\
\text { boundary rod } \\
\text { positions } \\
\text { Weapons-grade } \mathrm{PuO}_{2} \\
3.5 \text { wt } \% \text { for all other } \\
\text { rod positions }\end{array}$ & $\begin{array}{c}\text { Weapons-grade } \mathrm{PuO}_{2} \\
2.0 \text { wt } \% \text { at }(1,1) \text {, } \\
(1,2) \text {, and }(9,1) \text { corner } \\
\text { rod positions } \\
\text { Weapons-grade } \mathrm{PuO}_{2} \\
2.5 \text { wt\% at }(2 \text { to } 8,1) \text {, } \\
\text { and }(9,2 \text { to } 9) \\
\text { boundary rod } \\
\text { positions } \\
\text { Weapons-grade } \mathrm{PuO}_{2} \\
3.5 \text { wt\% for all other } \\
\text { rod positions }\end{array}$ \\
\hline \multirow[t]{2}{*}{ Checkerboard 4} & \multirow[t]{2}{*}{$\begin{array}{l}\mathrm{UO}_{2} \text { twice-burnt, at } \\
\text { the end of second } \\
\text { cycle }\end{array}$} & Assembly 2 & Assembly 3 \\
\hline & & $\begin{array}{l}\text { Same as checkerboard } \\
\text { 3, WG-MOX once } \\
\text { burnt at the end of first } \\
\text { cycle }\end{array}$ & $\begin{array}{l}\text { Same as checkerboard } \\
\text { 3, WG-MOX once } \\
\text { burnt at the end of first } \\
\text { cycle }\end{array}$ \\
\hline
\end{tabular}

See Figure 18 for orientation of assemblies 1,2,3, and 4 .

b See Table 28 for the coordinates of rod position (column, row). 
Figure 17. Relation of the PWR infinite core multiplication factor $\left(K_{\infty}\right)^{*}$ to fuel pin pitch for low-enriched $\mathrm{UO}_{2}$ and weapons-grade MOX fuel lattices.

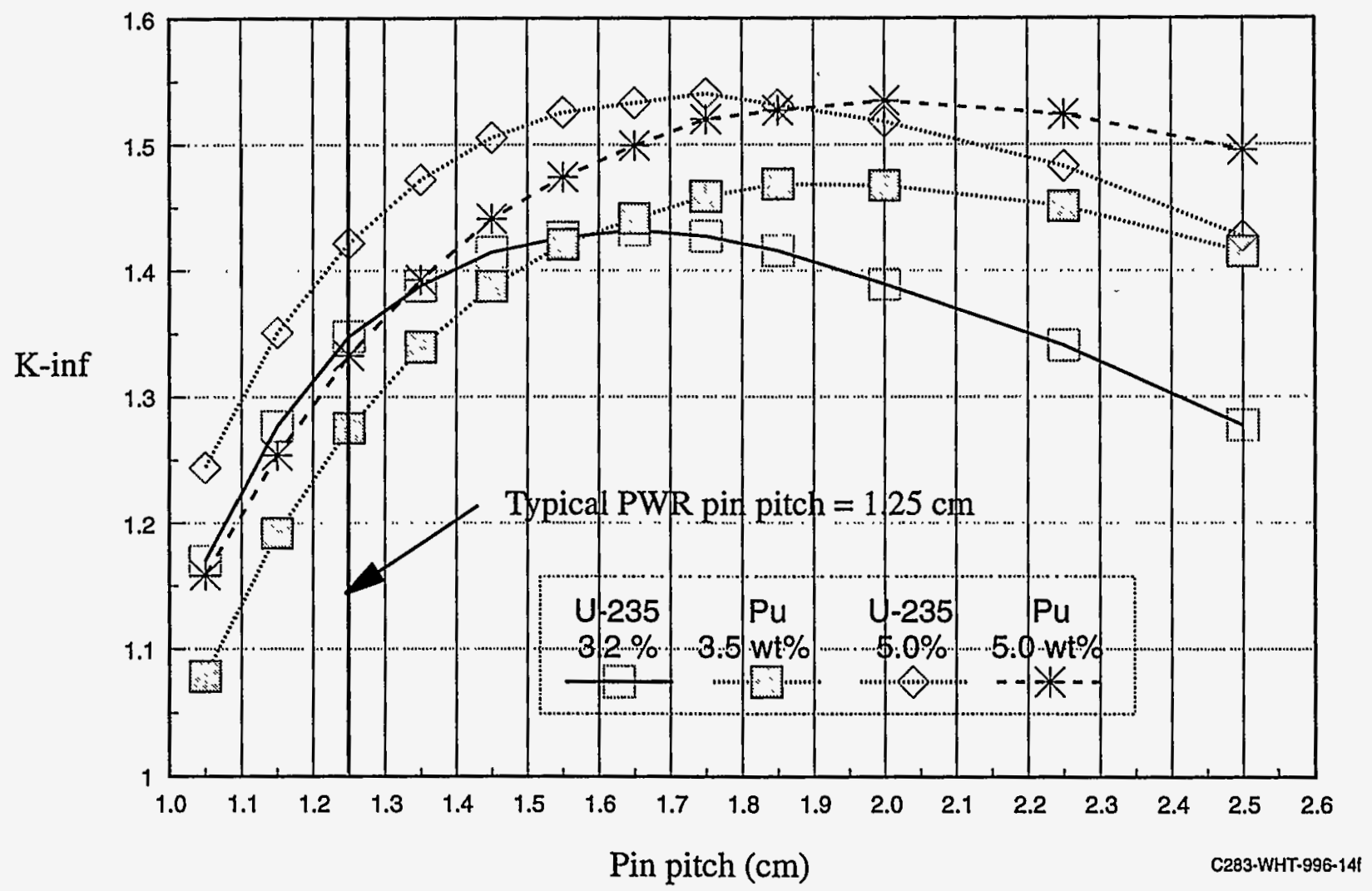

* One uncertainty band $(1 \sigma)$ of MCNP-calculated $K_{\infty}= \pm 0.0015$. 
From reactor physics theory, we know that when the water-to-uranium volume ratio decreases, the thermal utilization ( $f$ ) increases and the resonance escape probability (p) decreases. The multiplication factor in an infinite thermal reactor is the product $\mathrm{K}_{\infty}=\eta \varepsilon p f$ (for simplicity, $\eta$ and $\varepsilon$ are kept as constants). If the resonance escape probability (p) decreases while the (f) reaches its plateau as the pin pitch increases, then $\mathrm{K}_{\infty}$ should go through a maximum at some lattice configuration. Because the total thermal absorption cross section is about $50 \%$ higher in ${ }^{239} \mathrm{Pu}$ than in ${ }^{235} \mathrm{U}$, the MOX fuel lattice shows a considerable spectrum hardening. We can see clearly from Figure 17 that the values of the pin pitch where the peaks in $\mathrm{K}_{\infty}$ occur have pushed from 1.6 for $\mathrm{UO}_{2}$ to $2.0 \mathrm{~cm}$ for WG-MOX lattices. The effect of higher ${ }^{239} \mathrm{Pu}$ absorption also appears as a much higher ratio of fast neutron flux $(\mathrm{E}>0.625 \mathrm{eV})$ to thermal neutron flux. The fast-to-thermal neutron flux ratios of $\mathrm{UO}_{2}$ and WG-MOX fuel lattices with a pin pitch of $1.25 \mathrm{~cm}$ are 9.2 and 18.9 , respectively. However, all the cases in this study with a reference pin pitch of $1.25 \mathrm{~cm}$ have a strong positive slope at the undermoderated (left) side, which will make the isothermal temperature coefficient negative.

Typical PWR core data are: active height $366 \mathrm{~cm}$, active diameter $337 \mathrm{~cm}$, number of fuel assemblies 193, fuel-element array $17 \times 17$, and total number of fuel locations 50,952. Four cells are needed to describe the fuel pin, gap/integrated burnable absorber, cladding tube, and water coolant in each fuel location. To evaluate the mixed $\mathrm{UO}_{2}$ and WG-MOX assembly fuel cycle performance, a detailed checkerboard pin-by-pin fuel assembly model was used. A typical PWR fuel assembly was selected to generate the CBFAM. The layout of the CBFAM is shown in Figure 16. Four checkerboard cases (as tabulated in the bottom half of Table 27) were investigated in this study. There are four $\mathrm{UO}_{2}$ assemblies in checkerboard 1. Table 28 displays the values of $\mathrm{K}_{\infty}$ and relative pin power that were calculated for the \#1 CBFAM by MCNP. For all the checkerboard MCNP cases, 1,200,000 source particles were used, and the standard deviations of the $\mathrm{K}_{\infty}$ and pin power tallies are \pm 0.0005 and \pm 0.018 , respectively. For checkerboard 1 the PRPP is 1.058 , which easily meets the limit of 1.245. Checkerboard 2 consists of two $\mathrm{UO}_{2}$ assemblies (assemblies 1 and 4) and two WG-MOX fuel assemblies (assemblies 2 and 3). Because of its higher capture and fission cross sections, ${ }^{239} \mathrm{Pu}$ causes a large flux gradient between the WG-MOX and $\mathrm{UO}_{2}$ fuel assembly boundaries. The MCNP-calculated $\mathrm{K}_{\infty}$ and relative pin powers in the assemblies are shown in Table 29. The PRPP is 1.339 , which exceeds the limit of 1.245 . We improve on checkerboard 2 by lowering the WGPu wt\% in fuel rods at the boundaries and corners as specified in Table 27. The optimized checkerboard 3 has much better performance than checkerboard 2. Its MCNP-calculated $\mathrm{K}_{\infty}$ and relative pin power values in the assembly are shown in Table 30. The PRPP is 1.140 , which meets the design requirement at BOC. 
Checkerboards 3 and 4 are investigated in the fuel cycle performance analysis in the following section.

Table 28. MCNP-calculated normalized pin-power distribution in the $\mathrm{PWR} \mathrm{UO}_{2}$ fuel assemblies (checkerboard 1) at the beginning of fuel cycle ${ }^{a}$

\begin{tabular}{|c|c|c|c|c|c|c|c|c|c|c|c|c|c|c|c|c|c|c|}
\hline \multirow{3}{*}{ ID } & \multicolumn{9}{|c|}{ Assembly $1 \mathrm{UO}_{2}$} & \multicolumn{9}{|c|}{ Assembly $2 \mathrm{UO}_{2}$} \\
\hline & \multicolumn{9}{|c|}{ Peak relative pin power $=1.053$} & \multicolumn{9}{|c|}{ Peak relative pin power $=1.058$} \\
\hline & 1 & 2 & 3 & 4 & 5 & 6 & 7 & 8 & 9 & $T$ & 2 & 3 & 4 & 5 & 6 & 7 & 8 & 9 \\
\hline$T$ & & 1.01 & 1.02 & 0.00 & 1.00 & 1.03 & 0.00 & 1.01 & 0.99 & 0.98 & 1.00 & 0.00 & 1.01 & 1.01 & 0.00 & 1.01 & 1.00 & \\
\hline 2 & 1.01 & $\overline{0.99}$ & 1.01 & 1.01 & 0.98 & 0.98 & 1.00 & 0.99 & 1.00 & 0.99 & 0.98 & 1.01 & 1.00 & 0.99 & 1.02 & 0.99 & 0.98 & 1.00 \\
\hline 3 & 1.01 & 0.99 & 0.99 & 1.02 & 0.99 & 1.00 & 1.03 & 1.00 & 1.01 & 0.99 & 0.99 & 1.03 & 0.99 & 0.99 & 1.02 & 0.97 & 0.97 & 0.99 \\
\hline 4 & 0.00 & 1.01 & 1.02 & 0.00 & 1.02 & 1.04 & 0.00 & 1.01 & 1.00 & 1.01 & 1.02 & 0.00 & 1.03 & 1.02 & 0.00 & 1.01 & 1.00 & 0.00 \\
\hline 5 & 1.00 & 0.98 & 0.99 & 1.03 & 1.01 & 1.05 & 1.02 & 1.00 & 1.00 & 0.99 & 0.98 & 1.04 & 1.06 & 1.00 & 1.01 & 0.98 & 0.99 & 1.02 \\
\hline 6 & 1.01 & 0.97 & 0.98 & 1.03 & 1.05 & 0.00 & 1.02 & 0.97 & 0.99 & 0.98 & 0.97 & 1.02 & 0.00 & 1.03 & 1.01 & 1.00 & 0.99 & 1.02 \\
\hline 7 & 0.00 & 1.02 & 1.00 & 0.00 & 1.02 & 1.00 & 0.98 & 0.95 & 0.98 & 0.97 & 0.95 & 0.97 & 1.01 & 1.03 & 0.00 & 1.02 & 1.01 & 0.00 \\
\hline 8 & 1.00 & 0.97 & 0.98 & 1.01 & 0.97 & 0.97 & 0.96 & 0.97 & 0.99 & 0.98 & 0.96 & 0.96 & 0.96 & 0.99 & 1.02 & 0.98 & 0.99 & 1.02 \\
\hline 9 & 0.99 & 0.98 & 1.00 & 0.99 & 0.98 & 0.96 & 0.97 & 0.98 & 1.02 & 0.99 & 1.00 & 0.99 & 0.97 & 0.99 & 1.01 & 1.00 & 1.02 & 0.99 \\
\hline $\bar{T}$ & 1.01 & 0.98 & $\overline{0.99}$ & 0.99 & $\overline{0.98}$ & 0.98 & $\overline{0.97}$ & $\overline{0.97}$ & 1.00 & 1.02 & $\overline{0.99}$ & $\overline{0.97}$ & 1.00 & $\overline{0.99}$ & 1.00 & 1.00 & $\overline{0.99}$ & 1.00 \\
\hline$\overline{2}$ & 1.02 & 0.98 & 0.99 & 1.00 & 0.98 & 0.97 & 0.95 & 0.94 & 0.97 & 0.98 & 0.96 & 0.96 & 0.98 & 0.98 & 1.01 & 0.99 & 1.00 & 1.02 \\
\hline 3 & 0.00 & 1.03 & 1.02 & 0.00 & 1.03 & 1.01 & 0.98 & 0.97 & 0.99 & 0.98 & 0.95 & 0.98 & 1.02 & 1.03 & 0.00 & 1.01 & 1.01 & 0.00 \\
\hline 4 & 1.02 & 1.01 & 0.99 & 1.02 & 1.03 & 0.00 & 1.00 & $0 . \overline{97}$ & 0.98 & 0.98 & 0.99 & 1.02 & 0.00 & 1.05 & 1.03 & 0.99 & 0.99 & 1.00 \\
\hline 5 & 1.03 & 1.00 & 1.00 & 1.03 & 1.01 & 1.02 & 1.02 & $\overline{0.98}$ & 1.01 & 0.99 & 0.99 & 1.02 & 1.03 & 1.03 & 1.02 & 0.98 & $1.00^{\circ}$ & 1.00 \\
\hline 6 & 0.00 & 1.02 & 1.01 & 0.00 & 1.03 & 1.03 & $\overline{0.00}$ & 1.02 & 1.00 & 1.01 & 1.02 & 0.00 & 1.05 & 1.03 & 0.00 & 1.03 & 1.01 & 0.00 \\
\hline 7 & 1.05 & 0.99 & 0.99 & 1.02 & 1.01 & 0.99 & 1.03 & 0.99 & 1.00 & 1.01 & 0.99 & 1.02 & 0.99 & 1.00 & 1.02 & 1.00 & 0.99 & 1.02 \\
\hline 8 & 1.04 & 1.02 & 1.00 & 1.04 & 1.00 & 0.98 & 1.02 & 0.99 & 1.01 & 1.00 & 1.00 & 1.02 & 1.01 & 1.01 & 1.04 & 1.00 & 0.99 & 1.02 \\
\hline 9 & & 1.04 & 1.03 & 0.00 & 1.02 & 1.01 & 0.00 & 1.01 & 1.00 & 1.01 & 1.01 & 0.00 & 1.03 & 1.02 & 0.00 & 1.01 & 1.04 & \\
\hline & \multicolumn{9}{|c|}{ Peak relative pin power $=1.055$} & \multicolumn{9}{|c|}{ Peak relative pin power $=1.052$} \\
\hline & \multicolumn{9}{|c|}{ Assembly $3 \mathrm{UO}_{2}$} & \multicolumn{9}{|c|}{ Assembly $4 \mathrm{UO}_{2}$} \\
\hline
\end{tabular}

${ }^{a}$ MCNP-calculated $\mathrm{K}_{\infty}=1.3597 \pm 0.0004$.

Note: the peak value of relative pin power in each assembly is underlined. Since values are given in the lattice to only two decimal places, some unit cells appear to have values equal to the peak because of round-off error; the actual peak values are given to three decimal places in the borders. 
Table 29. MCNP-calculated normalized pin-power distribution in the mixed $\mathrm{UO}_{2}$ and WG-MOX PWR fuel assemblies (checkerboard 2) at the beginning of fuel cycle ${ }^{a}$

\begin{tabular}{|c|c|c|c|c|c|c|c|c|c|c|c|c|c|c|c|c|c|c|}
\hline \multirow{3}{*}{ ID } & \multicolumn{9}{|c|}{ Assembly $1 \mathrm{UO}_{2}$} & \multicolumn{9}{|c|}{ Assembly 2 MOX } \\
\hline & \multicolumn{9}{|c|}{ Peak relative pin power $=1.103$} & \multicolumn{9}{|c|}{ Peak relative pin power $=1.339$} \\
\hline & T & 2 & 3 & 4 & 5 & 6 & 7 & 8 & 9 & 1 & 2 & 3 & 4 & 5 & 6 & 7 & 8 & 9 \\
\hline T & & 1.08 & 1.07 & 0.00 & 1.05 & 1.05 & $\overline{0.00}$ & 0.96 & 0.85 & 1.21 & 1.04 & 0.00 & 0.94 & 0.96 & 0.00 & 0.96 & 0.95 & \\
\hline 2 & 1.07 & 1.06 & 1.05 & 1.07 & $\overline{1.03}$ & 1.01 & 1.02 & 0.94 & 0.84 & 1.20 & 1.01 & 1.01 & 0.90 & 0.90 & 0.95 & 0.90 & $0 . \overline{92}$ & 1.00 \\
\hline 3 & 1.10 & 1.06 & 1.06 & 1.08 & 1.06 & 1.01 & 1.02 & $\overline{0.93}$ & 0.83 & 1.23 & 1.00 & 0.97 & 0.91 & 0.91 & 0.94 & 0.91 & 0.90 & $0 . \overline{09}$ \\
\hline 4 & 0.00 & 1.08 & 1.09 & 0.00 & 1.07 & 1.07 & 0.00 & 0.94 & 0.86 & 1.20 & 1.06 & 0.00 & 1.01 & 0.98 & 0.00 & 0.97 & 0.95 & $\overline{0.00}$ \\
\hline 5 & 1.08 & 1.03 & 1.03 & 1.09 & 1.06 & 1.08 & 1.02 & 0.90 & 0.84 & 1.19 & 1.00 & $\overline{1.03}$ & 1.00 & 0.96 & $\overline{0.97}$ & 0.91 & 0.91 & 0.93 \\
\hline 6 & 1.05 & 1.04 & 1.02 & 1.07 & 1.06 & 0.00 & 1.00 & 0.88 & 0.81 & 1.19 & 0.96 & 1.01 & 0.00 & 1.03 & 0.97 & 0.92 & 0.92 & 0.98 \\
\hline 7 & 0.00 & 1.02 & 1.04 & 0.00 & 1.02 & 1.01 & 0.95 & 0.87 & $\overline{0.81}$ & 1.19 & 0.97 & 0.96 & 1.00 & 1.02 & 0.00 & 0.99 & 1.00 & 0.00 \\
\hline 8 & 0.93 & 0.94 & 0.93 & 0.96 & $\overline{0.94}$ & 0.91 & 0.86 & 0.83 & 0.80 & 1.19 & 1.02 & 0.99 & 0.98 & 0.99 & 1.06 & 1.02 & 1.01 & 1.03 \\
\hline 9 & 0.86 & 0.85 & 0.85 & 0.85 & 0.83 & $\overline{0.84}$ & 0.82 & 0.80 & 0.78 & 1.34 & 1.21 & 1.16 & 1.21 & 1.21 & 1.19 & 1.21 & 1.19 & 1.20 \\
\hline $\bar{l}$ & 1.20 & 1.22 & 1.21 & 1.19 & 1.23 & 1.19 & 1.17 & 1.21 & 1.31 & 0.80 & $0 . \overline{0.80}$ & 0.83 & 0.84 & $\overline{0.85}$ & $\overline{0.85}$ & 0.86 & $\overline{0.86}$ & $\overline{0.86}$ \\
\hline 2 & 1.01 & 0.99 & 1.01 & 1.06 & 0.98 & $\overline{0.97}$ & 0.99 & 1.02 & 1.21 & 0.81 & 0.85 & 0.88 & 0.91 & 0.93 & 0.97 & 0.94 & 0.93 & 0.93 \\
\hline 3 & 0.00 & 0.98 & 1.00 & 0.00 & 1.07 & 1.01 & 0.95 & 0.98 & 1.16 & 0.82 & 0.89 & 0.95 & 0.99 & 1.03 & 0.00 & 1.03 & 1.04 & 0.00 \\
\hline 4 & 0.95 & 0.92 & 0.91 & 0.98 & 1.02 & 0.00 & 0.99 & 1.00 & 1.18 & 0.83 & 0.91 & 1.00 & 0.00 & 1.08 & 1.07 & 1.03 & 1.02 & 1.08 \\
\hline 5 & 1.00 & $0 . \overline{92}$ & 0.91 & 0.98 & 0.97 & 1.01 & 1.04 & 1.01 & 1.20 & $\overline{0.84}$ & 0.92 & 1.03 & 1.07 & 1.04 & 1.08 & 1.05 & 1.06 & 1.07 \\
\hline 6 & 0.00 & $\overline{0.92}$ & 0.94 & 0.00 & 0.98 & 1.02 & 0.00 & 1.04 & 1.22 & 0.85 & 0.97 & 0.00 & 1.06 & 1.08 & 0.00 & 1.08 & 1.08 & 0.00 \\
\hline 7 & $\overline{0.93}$ & 0.90 & 0.91 & 0.94 & $\overline{0.92}$ & 0.94 & 0.99 & 1.01 & 1.19 & 0.85 & 0.95 & 1.03 & $\overline{1.03}$ & 1.07 & 1.10 & 1.07 & 1.08 & 1.11 \\
\hline 8 & $\overline{0.94}$ & 0.91 & 0.92 & 0.95 & 0.91 & 0.93 & 1.01 & 1.01 & 1.25 & $\overline{0.84}$ & 0.95 & 1.03 & 1.04 & 1.05 & 1.11 & 1.08 & 1.08 & 1.13 \\
\hline 9 & & 0.96 & 0.99 & 0.00 & $\overline{0.93}$ & 0.96 & 0.00 & 1.05 & 1.23 & 0.86 & 0.98 & 0.00 & 1.06 & 1.09 & 0.00 & 1.12 & 1.10 & \\
\hline & \multicolumn{9}{|c|}{ Peak relative pin power $=1.311$} & \multicolumn{9}{|c|}{ Peak relative pin power $=1.131$} \\
\hline & \multicolumn{9}{|c|}{ Assembly 3 MOX } & \multicolumn{9}{|c|}{ Assembly $4 \mathrm{UO}_{2}$} \\
\hline
\end{tabular}

${ }^{\mathrm{a}}$ MCNP-calculated $\mathrm{K}_{\infty}=1.4245 \pm 0.0005$.

Note: the peak value of relative pin power in each assembly is underlined. Since values are given in the lattice to only two decimal places, some unit cells appear to have values equal to the peak because of round-off error; the actual peak values are given to three decimal places in the borders. 
Table 30. MCNP-calculated normalized pin-power distribution in the mixed $\mathrm{UO}_{2}$ and WG-MOX PWR fuel assemblies (checkerboard 3) at the beginning of fuel cycle ${ }^{a}$

\begin{tabular}{|c|c|c|c|c|c|c|c|c|c|c|c|c|c|c|c|c|c|c|}
\hline \multirow{3}{*}{ ID } & \multicolumn{9}{|c|}{ Assembly $1 \mathrm{UO}_{2}$} & \multicolumn{9}{|c|}{ Assembly 2 MOX } \\
\hline & \multicolumn{9}{|c|}{ Peak relative pin power $=1.101$} & \multicolumn{9}{|c|}{ Peak relative pin power $=1.140$} \\
\hline & $T$ & 2 & $\overline{3}$ & 4 & 5 & 6 & 7 & 8 & 9 & 1 & 2 & 3 & 4 & 5 & 6 & 7 & 8 & 9 \\
\hline 1 & & 1.05 & 1.08 & 0.00 & 1.06 & 1.05 & 0.00 & 0.97 & 0.87 & 0.92 & 0.78 & 0.00 & 1.00 & $\overline{0.99}$ & 0.00 & 0.97 & $\overline{0.97}$ & \\
\hline 2 & 1.07 & 1.06 & 1.05 & 1.09 & 1.05 & $1.0 \overline{3}$ & 1.02 & $\overline{0.93}$ & 0.87 & 1.06 & 1.07 & 1.02 & 0.94 & $\overline{0.93}$ & 0.98 & 0.91 & 0.90 & 0.93 \\
\hline 3 & 1.08 & 1.05 & 1.04 & 1.09 & 1.05 & 1.04 & 1.02 & 0.92 & 0.88 & 1.04 & 1.04 & 1.02 & 0.95 & $\overline{0.93}$ & 0.99 & 0.92 & 0.92 & 0.96 \\
\hline 4 & 0.00 & 1.10 & 1.06 & 0.00 & 1.07 & 1.07 & 0.00 & 0.96 & 0.86 & 1.03 & 1.11 & 0.00 & 1.01 & 1.00 & 0.00 & 0.99 & 0.98 & 0.00 \\
\hline 5 & 1.04 & 1.04 & 1.05 & 1.09 & 1.06 & 1.06 & 1.01 & 0.94 & 0.88 & 1.03 & 1.06 & 1.07 & 1.03 & 0.96 & 1.00 & 0.93 & 0.96 & 0.98 \\
\hline 6 & 1.04 & 1.02 & 1.02 & 1.06 & 1.06 & 0.00 & 1.01 & 0.93 & 0.85 & 1.04 & 1.05 & 1.06 & 0.00 & 1.04 & 1.03 & 0.97 & 0.92 & 0.99 \\
\hline 7 & 0.00 & 1.03 & 1.02 & 0.00 & 1.03 & 1.02 & 0.95 & 0.89 & 0.87 & 1.06 & 1.08 & 1.01 & 1.04 & 1.06 & 0.00 & 1.01 & 1.05 & 0.00 \\
\hline 8 & 0.99 & 0.97 & 0.95 & 0.95 & 0.95 & 0.93 & 0.87 & 0.86 & 0.83 & 1.08 & 1.11 & 1.04 & 1.06 & 1.08 & 1.12 & 1.07 & 1.06 & 1.14 \\
\hline 9 & 0.88 & 0.88 & 0.88 & 0.88 & 0.86 & 0.86 & 0.86 & 0.85 & $\overline{0.84}$ & 1.02 & 1.07 & 1.03 & 1.03 & 1.05 & 1.05 & 1.05 & 1.04 & 1.05 \\
\hline $\bar{I}$ & 0.95 & $\overline{1} . \overline{09}$ & $1 . \overline{07}$ & 1.06 & $1 . \overline{04}$ & 1.03 & 1.02 & 1.06 & 1.02 & $\overline{0.86}$ & $\overline{0.84}$ & 0.83 & $\overline{0.85}$ & 0.87 & 0.87 & 0.87 & $0 . \overline{88}$ & $\overline{0.89}$ \\
\hline 2 & 0.80 & 1.10 & 1.12 & 1.12 & 1.08 & 1.07 & 1.03 & 1.10 & 1.06 & 0.84 & 0.88 & 0.92 & 0.92 & 0.95 & 0.99 & 0.96 & 0.96 & 0.99 \\
\hline 3 & 0.00 & 1.06 & 1.02 & 0.00 & 1.09 & 1.03 & 1.00 & 1.01 & 1.04 & 0.84 & 0.90 & 0.96 & 1.02 & 1.06 & 0.00 & 1.02 & 1.02 & $\overline{0.00}$ \\
\hline 4 & 1.04 & 0.97 & 0.95 & 1.03 & 1.05 & 0.00 & 1.03 & 1.06 & 1.02 & 0.88 & $\overline{0.92}$ & 1.01 & 0.00 & 1.08 & 1.07 & 1.03 & 1.04 & 1.07 \\
\hline 5 & 0.99 & 0.92 & $\overline{0.94}$ & 1.01 & $\overline{0.98}$ & 1.08 & 1.05 & 1.09 & 1.05 & 0.88 & 0.97 & 1.04 & 1.07 & 1.07 & 1.09 & 1.05 & 1.06 & 1.06 \\
\hline 6 & $\overline{0.00}$ & 0.97 & 0.98 & 0.00 & $\overline{0.98}$ & 1.02 & $\overline{0.00}$ & 1.12 & 1.05 & 0.89 & 0.98 & 0.00 & 1.08 & 1.09 & 0.00 & 1.10 & 1.09 & 0.00 \\
\hline 7 & 0.98 & 0.94 & $\overline{0.94}$ & 0.97 & 0.92 & 0.97 & 1.03 & 1.08 & 1.03 & 0.88 & 0.95 & 1.05 & 1.05 & 1.06 & 1.06 & 1.06 & 1.04 & 1.10 \\
\hline 8 & 0.98 & 0.93 & $\overline{0.92}$ & 0.98 & 0.94 & $\overline{0.93}$ & 1.04 & 1.08 & 1.07 & 0.89 & 0.98 & 1.02 & 1.03 & 1.07 & 1.08 & 1.06 & 1.04 & 1.09 \\
\hline 9 & & 1.00 & 0.97 & 0.00 & 1.00 & 1.01 & 0.00 & 1.11 & 1.06 & 0.88 & 1.01 & 0.00 & 1.04 & 1.06 & 0.00 & 1.09 & 1.07 & \\
\hline & \multicolumn{9}{|c|}{ Peak relative pin power $=1.121$} & \multicolumn{9}{|c|}{ Peak relative pin power $=1.097$} \\
\hline & \multicolumn{9}{|c|}{ Assembly 3 MOX } & \multicolumn{9}{|c|}{ Assembly $4 \mathrm{UO}_{2}$} \\
\hline
\end{tabular}

a $\quad$ MCNP-calculated $\mathrm{K}_{\infty}=1.3088 \pm 0.0005$.

Note: the peak value of relative pin power in each assembly is underlined. Since values are given in the lattice to only two decimal places, some unit cells appear to have values equal to the peak because of round-off error; the actual peak values are given to three decimal places in the borders. 


\subsection{Mixed Fuel Assembly Burnup Analysis}

From the neutronics viewpoint, only a few chains of isotopes and fission products (i.e. U-Pu, ${ }^{149} \mathrm{Sm}$, and ${ }^{135} \mathrm{Xe}$ chains from fuel irradiation in a reactor) need to be considered in the ORIGEN2 calculations. In this study, the BDOGXS of nuclides whose reactions are important to criticality were updated in the fuel burnup analysis. The MCNP and ORIGEN2 burnup calculations were performed for the CBFAM fuel assemblies at hot full power, without boron, and with all control rods out. This study is based on a typical PWR (3411 MW) with 300 effective full-power days (EFPD) for each fuel burnup cycle.

In the fuel burnup calculations, we used MCNP- and ORIGEN2-calculated BDOGXS and fuel compositions in several configurations: at BOC without xenon (Xe) and samarium (Sm), at BOC with equilibrium Xe and Sm, at the end of $150 \mathrm{EFPD}$, and at the ends of the 1st, 2nd, and 3rd cycles. In the mixed $\mathrm{UO}_{2}$ and WG-MOX fuel cycle burnup analysis, a detailed pin-by-pin checkerboard fuel assembly model was built for the MCNP calculations. Then ORIGEN2 used the MCNP-calculated flux and one-group cross sections to deplete and build up the radioactive isotopes pin-by-pin in the mixed fuel assembly burnup analysis. The inventories of these isotopes were compared as functions of burnup. An optimal checkerboard 3 of the mixed $\mathrm{UO}_{2}$ and WGMOX fuel assembly was selected, which assures that the PRPP is less than 1.245 at BOC. Such parameters as the excess core reactivity, ratio of ${ }^{240} \mathrm{Pu}$ to $\mathrm{Pu}$, and PRPP are examined.

The MCNP- and ORIGEN2-calculated $\mathrm{K}_{\infty}$, the ratio of ${ }^{240} \mathrm{Pu}$ to $\mathrm{Pu}$, and the PRPP are tabulated as functions of burnup in Table 31. Because of the Xe and Sm buildup, $\mathrm{K}_{\infty}$ decreases rapidly until the end of the fifth EFPD, then decreases linearly toward the end of the third cycle. At the end of the second fuel cycle, the ${ }^{240} \mathrm{Pu} / \mathrm{Pu}$ ratios in fuel rods of $3.5,2.5$, and $2.0 \mathrm{wt} \% \mathrm{WGPu}$ reach $24.96 \%, 27.89 \%$ and $27.91 \%$, respectively. The relative pin power distribution at the end of the second cycle is also tabulated in Table 32. The PRPP at the end of the second cycle is 1.141, which meets the design limit constraint on PRPP. Note that $\mathrm{K}_{\infty}$ at the end of third cycle is 1.0935 .

To demonstrate that checkerboard 3 can achieve an adequate equilibrium fuel cycle, checkerboard 4, which contains twice-burnt $\mathrm{UO}_{2}$ assemblies and once-burnt WG-MOX assemblies as specified in Table 27 , is analyzed. Its relative pin power distribution in the assembly and $\mathrm{K}_{\infty}$ $(1.1602 \pm 0.0005)$ are listed in Table 33. The PRPP of checkerboard 4 is 1.161 , which does not exceed the limiting value of 1.245 . 
Table $31 . \mathrm{K}_{\infty}$ peak relative pin power, and ${ }^{240} \mathrm{Pu} / \mathrm{Pu}$ ratio of the mixed $\mathrm{PWR}$ fuel assembly as functions of burnup for checkerboard 3

\begin{tabular}{|c|c|c|c|c|c|}
\hline \multirow[t]{2}{*}{ Case } & \multirow[t]{2}{*}{$\overline{\mathrm{K}_{\infty}}$} & \multirow{2}{*}{$\begin{array}{l}\text { Peak relative } \\
\text { pin power }\end{array}$} & \multicolumn{3}{|c|}{${ }^{240} \mathrm{Pu} / \mathrm{Pu}$ ratio (\%) } \\
\hline & & & $\begin{array}{l}\text { WG-PU } \\
3.5 \mathrm{wt} \%\end{array}$ & $\begin{array}{l}\text { WG-PU } \\
2.5 \mathrm{wt} \%\end{array}$ & $\begin{array}{l}\text { WG-PU } \\
2.0 \mathrm{wt} \%\end{array}$ \\
\hline$\overline{\mathrm{BOC}}$ without $\mathrm{Xe}$ and $\mathrm{Sm}$ & $1.3088^{\mathrm{a}}$ & $1.141^{\circ}$ & 5.92 & $5 . \overline{92}$ & 5.92 \\
\hline $\begin{array}{l}\text { At end of 5th EFPD with } \\
\text { equilibrium Xe and Sm }\end{array}$ & 1.2687 & 1.138 & 6.15 & 6.27 & 6.40 \\
\hline At end of 150th EFPD & 1.2178 & 1.143 & 12.06 & 14.10 & 14.88 \\
\hline $\begin{array}{l}\text { At end of first cycle } \\
\text { (300 EFPDs) }\end{array}$ & 1.1794 & 1.139 & 17.93 & 21.47 & 22.17 \\
\hline $\begin{array}{l}\text { At end of second cycle } \\
\text { (600 EFPDs) }\end{array}$ & 1.1314 & 1.141 & 24.96 & 27.89 & 27.91 \\
\hline $\begin{array}{l}\text { At end of third cycle } \\
\text { (900 EFPDs) }\end{array}$ & 1.0935 & 1.140 & 28.98 & 30.54 & 29.59 \\
\hline
\end{tabular}

a One standard deviation $= \pm 0.0005$.

b Average standard deviation $= \pm 0.018$.

\subsection{Summary of PWR Analysis}

A study using a CBFAM to analyze fuel assembly depletion in checkerboard 3 indicates that a representative equilibrium fuel cycle (checkerboard 4) can be developed. This study is based on a typical PWR (3411 MW) with 300 EFPD for one fuel burnup cycle. At the end of the second cycle, the ${ }^{240} \mathrm{Pu} / \mathrm{Pu}$ ratios in discharged fuel rods initially containing $3.5,2.5$, and $2.0 \mathrm{wt} \% \mathrm{WGPu}$ reach $24.96 \%, 27.89 \%$ and $27.91 \%$, respectively. We conclude that the mixed fuel assemblies can achieve the design goals as described in section 6. 1. The proposed mixed $\mathrm{UO}_{2}$ and WGMOX fuel assemblies can be applied in commercial LWRs without any major system modifications. 
Table 32. MCNP-calculated normalized pin-power distribution in the mixed $\mathrm{UO}_{2}$ and WG-MOX PWR fuel assemblies (checkerboard 3) at the end of second fuel cycle

\begin{tabular}{|c|c|c|c|c|c|c|c|c|c|c|c|c|c|c|c|c|c|c|}
\hline \multirow{2}{*}{ II } & \multicolumn{9}{|c|}{ Assembly $1 \mathrm{UO}_{2}$} & \multicolumn{9}{|c|}{ Assembly 2 MOX } \\
\hline & \multicolumn{9}{|c|}{ Peak relative pin power $=1.092$} & \multicolumn{9}{|c|}{ Peak relative pin power $=1.141$} \\
\hline & 1 & 2 & 3 & 4 & 5 & 6 & 7 & 8 & 9 & 1 & 2 & 3 & 4 & 5 & 6 & 7 & 8 & 9 \\
\hline$T$ & & 1.05 & 1.07 & 0.0 & 1.05 & 1.06 & 0.00 & 1.03 & 0.96 & 0.79 & 0.74 & 0.00 & 1.03 & 0.99 & 0.00 & 1.03 & 1.00 & \\
\hline 2 & 1.09 & 1.04 & 1.02 & 1.06 & 1.03 & 1.02 & 1.03 & 0.98 & 0.95 & 0.89 & 1.12 & 1.06 & 0.97 & 0.94 & 1.00 & 0.94 & 0.96 & 0.98 \\
\hline 3 & 1.06 & 1.03 & 1.02 & 1.05 & 1.02 & 1.04 & 1.04 & 0.98 & 0.95 & 0.88 & 1.10 & 1.08 & 0.98 & 0.95 & 1.03 & 0.95 & 0.95 & 0.99 \\
\hline 4 & 0.00 & 1.06 & 1.06 & 0.00 & 1.07 & 1.05 & 0.00 & 1.02 & 0.96 & $\overline{0.89}$ & 1.14 & 0.00 & 1.04 & 1.02 & 0.00 & 1.00 & 0.99 & 0.00 \\
\hline 5 & 1.08 & 1.01 & 1.03 & 1.05 & 1.03 & 1.05 & 1.04 & 0.98 & 0.95 & 0.88 & 1.07 & 1.08 & 1.06 & 1.02 & 1.03 & 0.98 & 0.96 & 1.00 \\
\hline 6 & 1.05 & 1.02 & 1.04 & 1.06 & 1.08 & 0.00 & 1.01 & 0.96 & 0.92 & 0.88 & 1.05 & 1.07 & 0.00 & 1.08 & 1.05 & 0.96 & 0.99 & 1.04 \\
\hline 7 & 0.00 & 1.02 & 1.03 & 0.00 & 1.05 & 1.03 & 0.97 & 0.95 & 0.93 & 0.87 & 1.08 & 1.00 & 1.08 & 1.10 & 0.00 & 1.05 & 1.05 & 0.00 \\
\hline 8 & 1.01 & 1.00 & 0.99 & 1.03 & 0.97 & 0.96 & 0.95 & 0.94 & 0.96 & 0.88 & 1.12 & 1.06 & 1.06 & 1.07 & 1.13 & 1.09 & 1.07 & 1.12 \\
\hline 9 & 0.97 & 0.98 & 0.98 & 1.00 & 0.95 & 0.96 & 0.95 & 0.95 & 0.98 & 0.84 & 0.90 & 0.88 & 0.88 & 0.89 & 0.88 & 0.88 & 0.89 & 0.90 \\
\hline l & 0.81 & 0.91 & 0.90 & 0.90 & 0.88 & 0.88 & 0.87 & 0.90 & 0.83 & $0 . \overline{97}$ & 0.94 & 0.94 & 0.95 & 0.95 & 0.96 & 0.96 & 0.96 & $0 . \overline{98}$ \\
\hline 2 & 0.76 & 1.11 & 1.09 & 1.12 & 1.09 & 1.05 & 1.07 & 1.12 & 0.89 & 0.96 & 0.94 & $0 . \overline{95}$ & 0.95 & $\overline{0.98}$ & 1.01 & 0.99 & 1.00 & 1.04 \\
\hline 3 & 0.00 & 1.05 & 1.07 & 0.00 & 1.09 & 1.06 & 1.03 & 1.05 & 0.89 & 0.94 & 0.95 & 0.97 & 1.03 & 1.06 & 0.00 & 1.05 & 1.04 & 0.00 \\
\hline 4 & 1.01 & $\overline{0.97}$ & 1.01 & 1.05 & 1.07 & 0.00 & 1.07 & 1.08 & 0.87 & 0.96 & 0.95 & 1.03 & 0.00 & 1.06 & 1.07 & 1.02 & 1.05 & 1.05 \\
\hline 5 & 0.99 & 0.96 & 0.98 & 1.03 & 1.03 & 1.03 & 1.05 & 1.08 & 0.88 & 0.95 & 0.98 & 1.05 & 1.04 & 1.05 & 1.05 & 1.03 & 1.01 & 1.04 \\
\hline 6 & 0.00 & 0.99 & 0.99 & 0.00 & 1.03 & 1.03 & 0.00 & 1.10 & 0.90 & 0.98 & 1.03 & 0.00 & 1.05 & 1.07 & 0.00 & 1.06 & 1.06 & 0.00 \\
\hline 7 & 0.98 & 0.95 & 0.95 & 1.01 & 0.97 & 0.96 & 1.07 & 1.08 & 0.88 & 0.96 & 0.99 & 1.03 & 1.01 & 1.03 & 1.06 & 1.03 & 1.03 & 1.06 \\
\hline 8 & 0.96 & 0.95 & 0.95 & 1.01 & 0.98 & 0.98 & 1.01 & 1.07 & 0.88 & 0.96 & 0.99 & 1.04 & 1.02 & 1.01 & 1.05 & 1.03 & 1.02 & 1.04 \\
\hline 9 & & 0.98 & 1.02 & 0.00 & 0.97 & 1.01 & 0.00 & 1.10 & 0.86 & 0.96 & 1.01 & 0.00 & 1.06 & 1.04 & 0.00 & 1.05 & 1.07 & \\
\hline & \multicolumn{9}{|c|}{ Peak relative pin power $=1.123$} & \multicolumn{9}{|c|}{ Peak relative pin power $=1.073$} \\
\hline & \multicolumn{9}{|c|}{ Assembly 3 MOX } & \multicolumn{9}{|c|}{ Assembly $4 \mathrm{UO}_{2}$} \\
\hline
\end{tabular}

${ }^{a}$ MCNP-calculated $\mathrm{K}_{\infty}=1.1314 \pm 0.0006$

Note: the peak value of relative pin power in each assembly is underlined. Since values are given in the lattice to only two decimal places, some unit cells appear to have values equal to the peak because of round-off error; the actual peak values are given to three decimal places in the borders. 
Table 33. MCNP-calculated normalized pin-power distribution in the mixed $\mathrm{UO}_{2}$ and WG-MOX PWR fuel assemblies (checkerboard 4) at the beginning of equilibrium fuel cycle ${ }^{2}$

\begin{tabular}{|c|c|c|c|c|c|c|c|c|c|c|c|c|c|c|c|c|c|c|}
\hline \multirow{3}{*}{ ID } & \multicolumn{9}{|c|}{ Assembly $1 \mathrm{UO}_{2}$} & \multicolumn{9}{|c|}{ Assembly 2 MOX } \\
\hline & \multicolumn{9}{|c|}{ Peak relative pin power $=1.050$} & \multicolumn{9}{|c|}{ Peak relative pin power $=1.160$} \\
\hline & $T$ & 2 & $\overline{3}$ & 4 & 5 & 6 & 7 & 8 & $\overline{9}$ & $T$ & 2 & 3 & 4 & 5 & 6 & 7 & 8 & 9 \\
\hline $\bar{I}$ & & 1.01 & 1.03 & 0.00 & 1.02 & 1.01 & 0.00 & 0.97 & 0.94 & 0.85 & 0.77 & 0.00 & 1.06 & 1.05 & 0.00 & 1.04 & 1.03 & \\
\hline 2 & 1.01 & 1.00 & 1.01 & 1.02 & 0.99 & 0.98 & 1.00 & 0.96 & 0.93 & 0.95 & 1.14 & 1.09 & 1.00 & 0.98 & 1.02 & 0.98 & 0.96 & 1.02 \\
\hline 3 & 1.02 & 1.00 & 0.98 & 1.03 & $\overline{1.01}$ & 0.99 & 1.00 & 0.96 & 0.91 & 0.95 & 1.09 & 1.06 & 1.01 & 0.99 & 1.03 & 0.97 & 0.99 & 1.03 \\
\hline 4 & 0.00 & 1.03 & 1.02 & 0.00 & 1.05 & 1.03 & $\overline{0.00}$ & 0.97 & 0.92 & $\overline{0.94}$ & $\overline{1.13}$ & $\overline{0.00}$ & 1.09 & 1.04 & 0.00 & 1.03 & 1.02 & 0.00 \\
\hline 5 & 1.02 & 1.01 & 1.00 & 1.04 & 1.04 & 1.05 & 1.02 & 0.95 & 0.90 & 0.92 & 1.11 & 1.11 & 1.11 & 1.04 & 1.05 & 0.99 & 0.98 & 1.01 \\
\hline 6 & 1.02 & 0.99 & 1.00 & 1.04 & 1.05 & $\overline{0.00}$ & 1.00 & 0.94 & 0.90 & 0.92 & 1.07 & 1.09 & 0.00 & 1.10 & 1.06 & 1.01 & 0.98 & 1.02 \\
\hline 7 & 0.00 & 1.02 & 1.02 & 0.00 & 1.02 & 1.00 & 0.95 & 0.91 & 0.90 & 0.92 & 1.05 & 1.04 & 1.09 & 1.13 & $\overline{0.00}$ & 1.07 & 1.08 & 0.00 \\
\hline 8 & 1.00 & 0.97 & 0.96 & 0.98 & 0.95 & 0.93 & 0.93 & 0.91 & 0.90 & 0.98 & 1.13 & 1.08 & 1.08 & 1.10 & 1.16 & 1.10 & 1.09 & 1.14 \\
\hline$\overline{9}$ & $\overline{0.94}$ & 0.93 & 0.92 & 0.92 & 0.91 & 0.92 & 0.90 & 0.90 & 0.94 & 0.90 & $\overline{0.97}$ & $\overline{0.92}$ & 0.92 & 0.94 & 0.95 & $\overline{0.93}$ & 0.92 & 0.94 \\
\hline$\overline{1}$ & 0.85 & $\overline{0.96}$ & $\overline{0.95}$ & $\overline{0.94}$ & $\overline{0.93}$ & $\overline{0.93}$ & 0.92 & $\overline{0.96}$ & 0.90 & 0.94 & 0.92 & 0.91 & 0.90 & $\overline{0.91}$ & 0.93 & $\overline{0.93}$ & $0 . \overline{92}$ & $\overline{0.93}$ \\
\hline 2 & 0.77 & 1.13 & 1.11 & 1.14 & 1.11 & 1.07 & 1.10 & 1.13 & 0.95 & 0.91 & 0.92 & 0.94 & 0.93 & 0.96 & 0.98 & 0.96 & 0.97 & 0.98 \\
\hline 3 & 0.00 & 1.09 & 1.08 & 0.00 & 1.09 & 1.09 & 1.05 & 1.07 & 0.93 & 0.90 & $\overline{0.90}$ & 0.95 & 0.98 & 1.00 & 0.00 & 1.01 & 1.01 & 0.00 \\
\hline 4 & 1.04 & 1.01 & 1.00 & 1.06 & 1.08 & 0.00 & 1.08 & 1.08 & 0.94 & 0.90 & 0.93 & 1.01 & 0.00 & 1.03 & 1.02 & 0.99 & 0.98 & 1.01 \\
\hline 5 & 1.03 & 0.98 & 1.00 & 1.04 & 1.06 & 1.07 & 1.10 & 1.10 & 0.93 & $\overline{0.92}$ & 0.97 & 1.02 & 1.04 & 1.03 & 1.04 & 1.02 & 0.99 & 1.04 \\
\hline 6 & 0.00 & 1.04 & 1.02 & 0.00 & 1.04 & 1.07 & 0.00 & 1.15 & 0.95 & 0.92 & $\overline{0.98}$ & 0.00 & 1.05 & 1.04 & 0.00 & 1.03 & 1.02 & 0.00 \\
\hline$\overline{7}$ & 1.01 & 0.97 & 0.98 & 1.03 & 0.98 & 1.01 & 1.07 & 1.10 & 0.95 & 0.92 & $\overline{0.97}$ & 1.01 & 1.00 & 1.01 & 1.03 & 0.99 & 1.00 & 1.01 \\
\hline 8 & 1.02 & 0.98 & 0.97 & $\overline{0.99}$ & 0.99 & 1.01 & 1.08 & 1.11 & 0.94 & 0.92 & 0.96 & 1.01 & 1.00 & 0.99 & 1.04 & 1.00 & 1.01 & 1.03 \\
\hline 9 & & 1.01 & 1.02 & 0.00 & 1.01 & 1.04 & 0.00 & 1.16 & 0.95 & 0.94 & 0.98 & 0.00 & 1.03 & 1.02 & 0.00 & 1.05 & 1.04 & \\
\hline & \multicolumn{9}{|c|}{ Peak relative pin power $=1.161$} & \multicolumn{9}{|c|}{ Peak relative pin power $=1.046$} \\
\hline & \multicolumn{9}{|c|}{ Assembly 3 MOX } & \multicolumn{9}{|c|}{ Assembly $4 \mathrm{UO}_{2}$} \\
\hline
\end{tabular}

${ }^{a}$ MCNP-calculated $\mathrm{K}_{\infty}=1.1602 \pm 0.0005$.

Note: the peak value of relative pin power in each assembly is underlined. Since values are given in the lattice to only two decimal places, sorne unit cells appear to have values equal to the peak because of round-off error; the actual peak values are given to three decimal places in the borders. 
The results of this study demonstrate that one comprehensive calculation step of the CBFAM can compute the important core physics parameters. MCNP does not have the capability to perform the time-dependent fuel depletion. However, MCNP can generate multigroup fluxes and cross sections for the fuel depletion and isotope generation calculation. Thus, a sequence of MCNP and fuel depletion computations can determine the isotope concentrations throughout the reactor operational cycle. We conclude that the CBFAM can not only provide an accurate pin power distribution to benchmark other core analysis codes, but it can also be applied in a mixed MOX $/ \mathrm{UO}_{2}$ fuel core design, a capsule design for WG-MOX fuel testing in ATR, a WG-MOX fuel lead test assembly design, and a weapons-grade nuclear materials disposition study.

\subsection{BWR and CANDU Models}

BWR and CANDU models were developed for use with the MCNP code. Figure 18 shows a plan view of an MCNP model of four $8 \times 8$-element BWR fuel assemblies. Figure 19 shows a side view of this same BWR model. Six regions are used axially to represent each fuel rod. The boiling water between the rods is represented by 24 axial regions. This provides adequate detail to model the boiling water, which enters the bottom of the core subcooled, then boils as it flows upward to the top of the core. Table 34 shows this effect, with a void fraction of 0.0 at the bottom of the core increasing to 0.66 at the top of the core. Table 34 also shows the corresponding axial distribution of water densities used in the MCNP model. Thus, the threedimensional MCNP model can accurately represent the axial variation in void fraction. This is important because the neutronics characteristics of BWRs change noticeably from bottom to top.

Figure 20 shows a side view of an MCNP model of a 37-element CANDU fuel assembly. The CANDU fuel assemblies are oriented horizontally in the core. Also, a significant amount of heavy water surrounds each fuel assembly. The CANDU model has been used to show that the ATR is also capable of testing CANDU MOX fuel in conditions similar to those present in CANDU reactors, as discussed for the issue of the neutron spectrum in the next section.

\subsection{Comparison of ATR, PWR, BWR, and CANDU Neutron Flux Spectra}

The neutron flux spectra used for testing MOX fuel should be similar to those found in commercial reactors burning MOX fuel. Some comparisons between the spectra in the ATR and a commercial PWR have been presented in our earlier work. ${ }^{3.4}$ These studies show that a hafnium shroud can be placed around the MOX target in the ATR to make the neutron spectrum harder and to reduce the linear heat generation rate in the target. Further comparisons are presented here. 


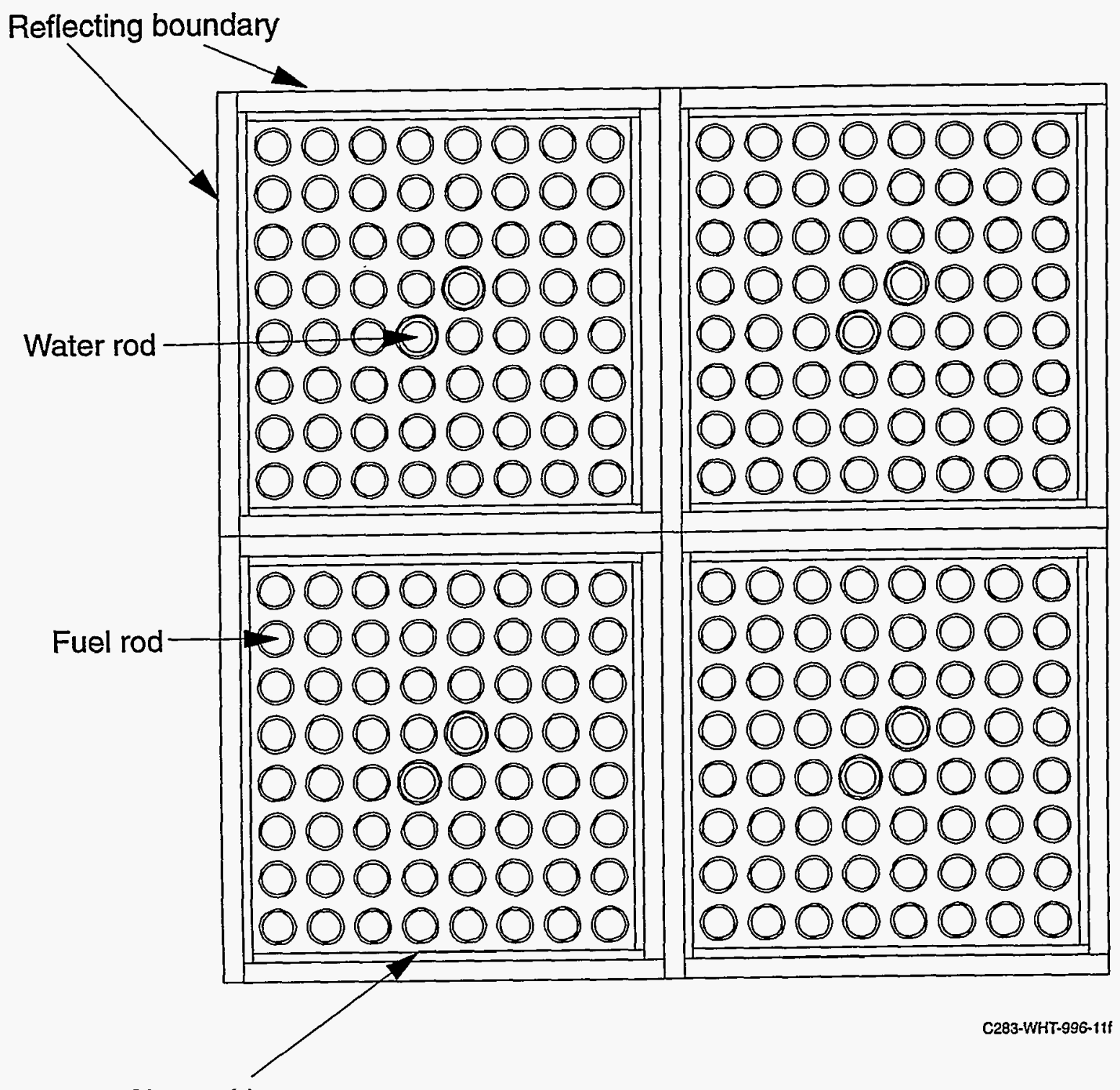

Channel box

Figure 18. Plan view of an MCNP model of four $8 \times 8$ element BWR- 6 fuel assemblies with reflective planes on a $30.5 \mathrm{~cm}$ square lattice. 


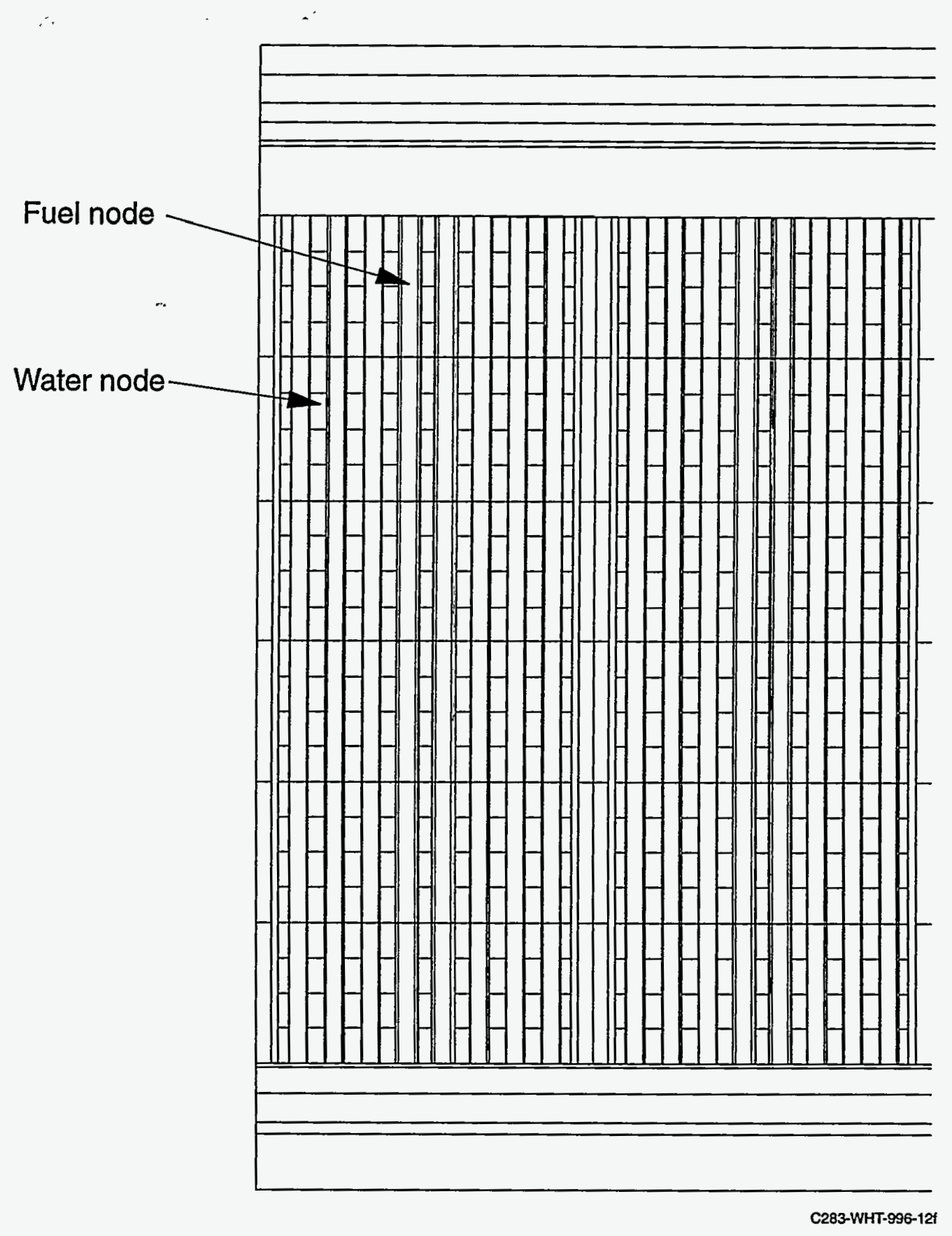

Figure 19. Side view of an MCNP model of four $8 \times 8$ element BWR- 6 fuel assemblies with 6 axial fuel nodes per rod and 24 axial water nodes. 
Table 34. Typical BWR-6 axial void fractions and water densities along the 376-cm active fuel length

\begin{tabular}{|c|c|c|}
\hline Node & Void Fraction & Water density $\left(\mathrm{g} / \mathrm{cm}^{3}\right)$ \\
\hline Top 1 & 0.66 & 0.25738 \\
\hline 2 & 0.66 & 0.25738 \\
\hline 3 & 0.65 & 0.26495 \\
\hline 4 & 0.64 & 0.27252 \\
\hline 5 & 0.64 & 0.27252 \\
\hline 6 & 0.63 & $\overline{0.28009}$ \\
\hline 7 & 0.62 & 0.28766 \\
\hline 8 & 0.61 & 0.29523 \\
\hline 9 & $\overline{0.59}$ & 0.31037 \\
\hline 10 & 0.58 & 0.31794 \\
\hline 11 & $\overline{0.56}$ & 0.33308 \\
\hline 12 & 0.54 & 0.34822 \\
\hline 13 & $\overline{0.51}$ & 0.37093 \\
\hline 14 & 0.48 & 0.39364 \\
\hline 15 & 0.44 & 0.42392 \\
\hline$\overline{16}$ & $\overline{0.40}$ & 0.45420 \\
\hline 17 & 0.35 & 0.49205 \\
\hline 18 & $\overline{0.28}$ & 0.54504 \\
\hline 19 & 0.21 & 0.59803 \\
\hline 20 & 0.13 & 0.65859 \\
\hline 21 & $\overline{0.06}$ & 0.71158 \\
\hline 22 & $\overline{0.02}$ & 0.74186 \\
\hline 23 & 0.00 & 0.75700 \\
\hline Bottom 24 & 0.00 & 0.75700 \\
\hline
\end{tabular}

Figure 21 compares normalized flux spectra in a typical PWR, two BWRs, and a CANDU, all fueled with $\mathrm{UO}_{2}$. The CANDU spectrum is noticeably softer (higher in the thermal neutron energy range) than for the PWR or BWRs. Figure 22 shows the normalized flux spectra in two BWRs (with different uranium enrichments) at the top, middle, and bottom of the reactor. The spectrum at the bottom is the softest because more water is present. In addition, the spectrum is 


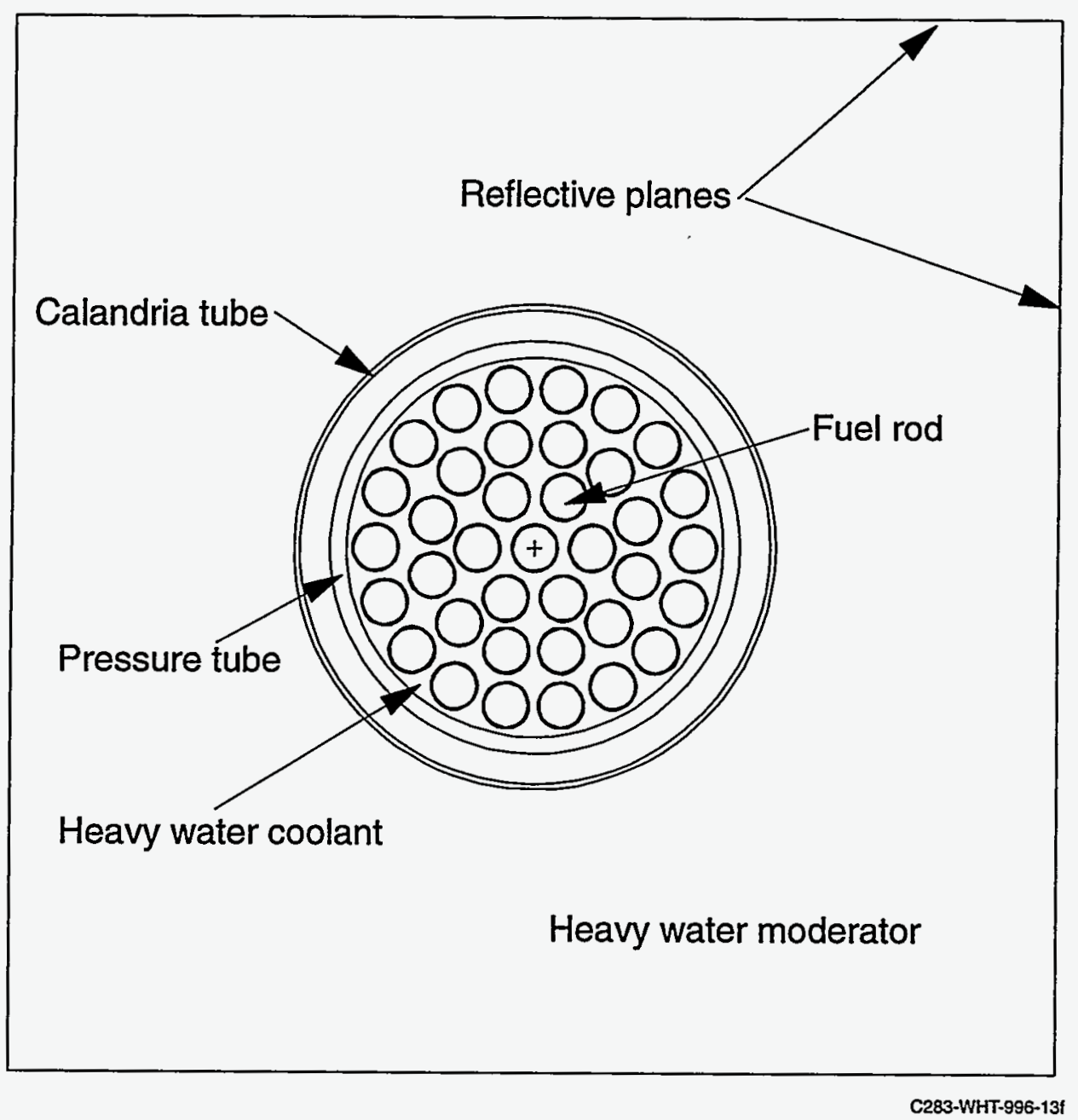

Figure 20. Side view of an MCNP model of a 37-element CANDU fuel assembly with reflective planes on a $28.6 \mathrm{~cm}$ square lattice. 
Figure 21. Comparison of normalized flux spectra in typical PWR, BWR, and CANDU $\mathrm{UO}_{2}$ fuel.

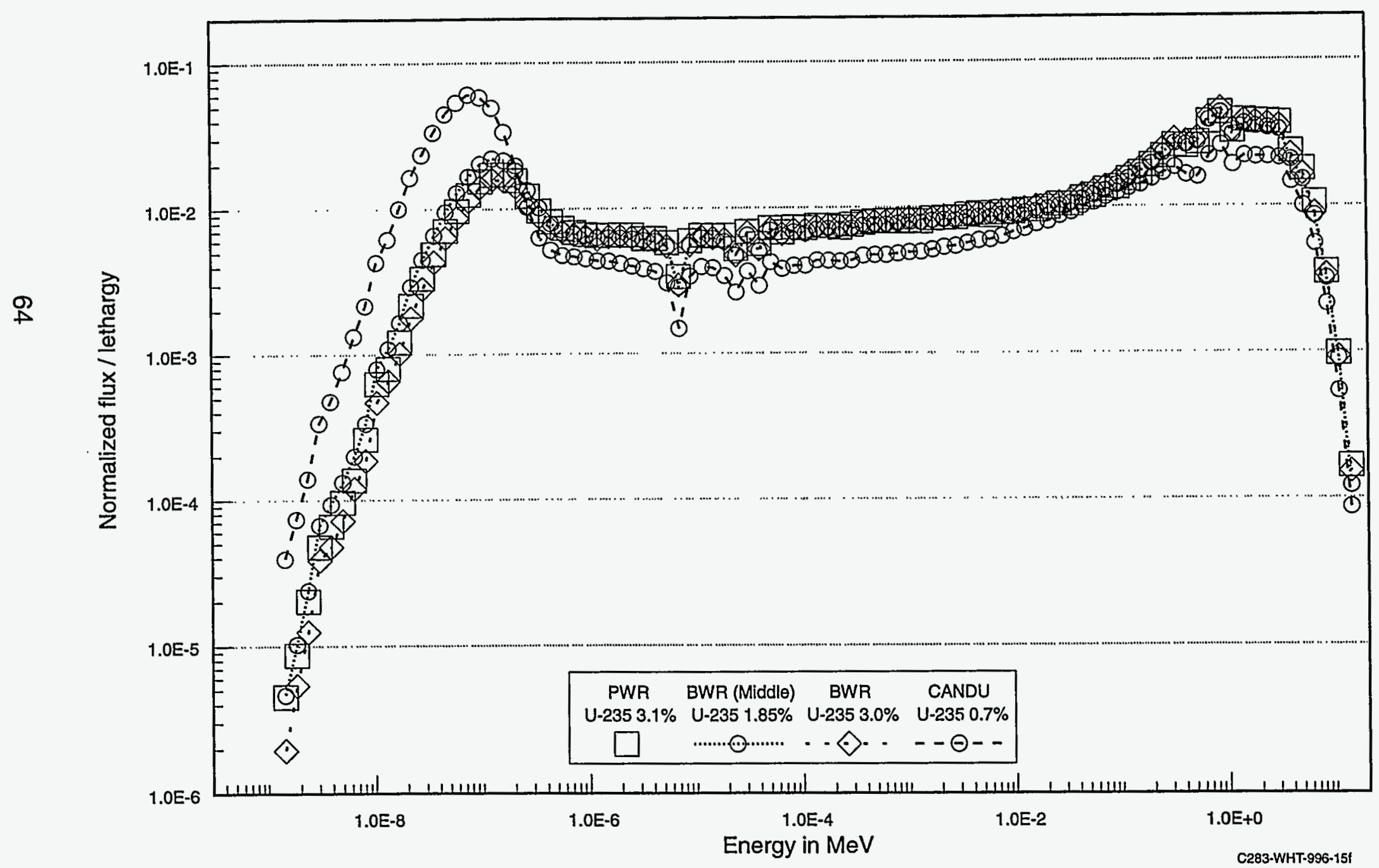


Figure 22. Comparison of normalized flux spectra of BWR $\mathrm{UO}_{2}$ fuel at top, middle, and bottom section.

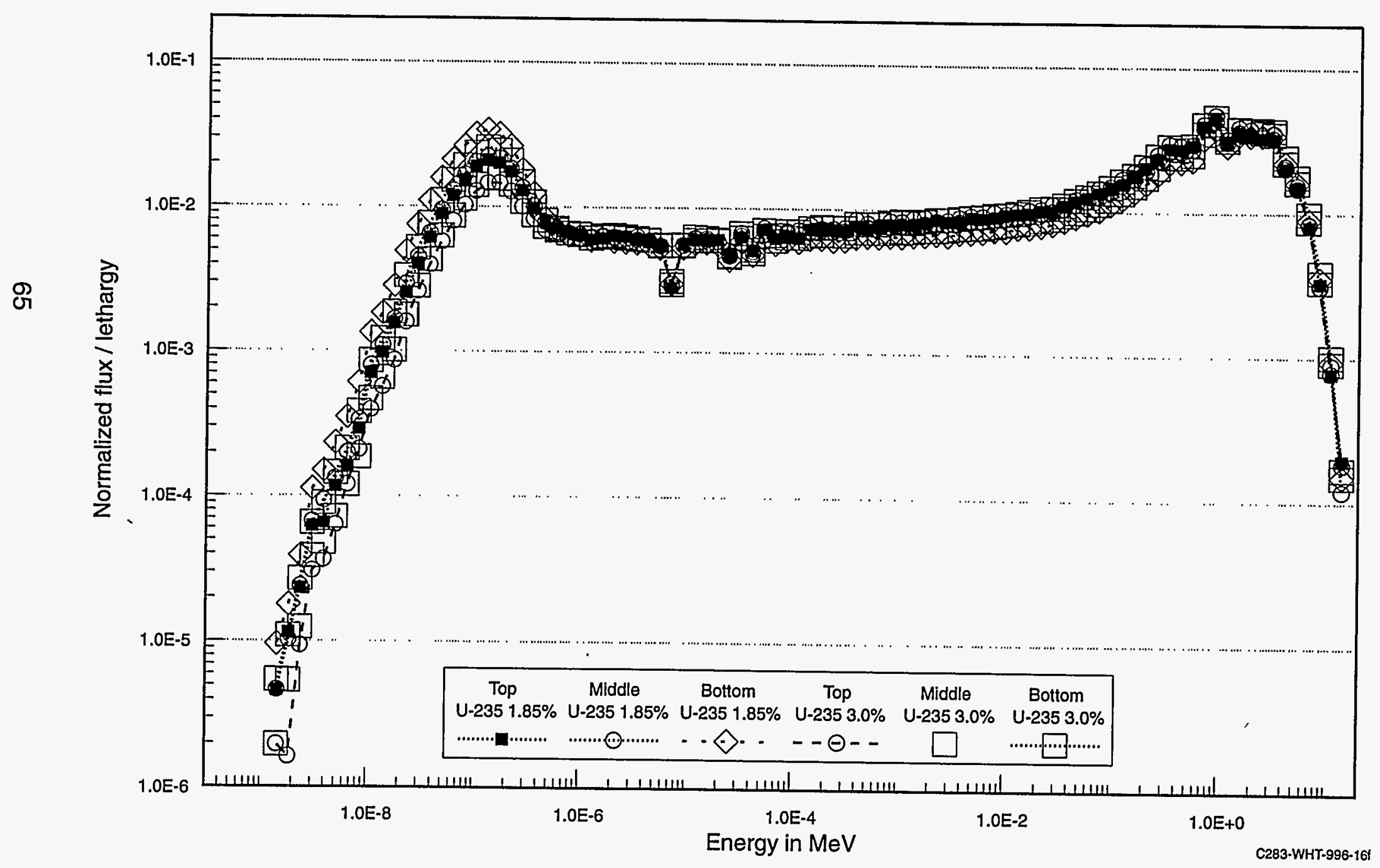


softer in the BWR with the lower uranium enrichment. Figure 23 shows the normalized flux spectra with MOX fuel in various ATR irradiation positions. The I-holes have softer spectra than the B-holes because the I-holes are located in the reflector farther away from the ATR fuel. Figure 24 compares the normalized flux spectra with MOX fuel in the ATR, a PWR, and a CANDU reactor. The spectra in the ATR reflector are similar to those in CANDU reactors, but much softer than the spectra in commercial PWRs containing full MOX cores. Hafnium shrouds can be used to make the ATR spectra harder if desired. 


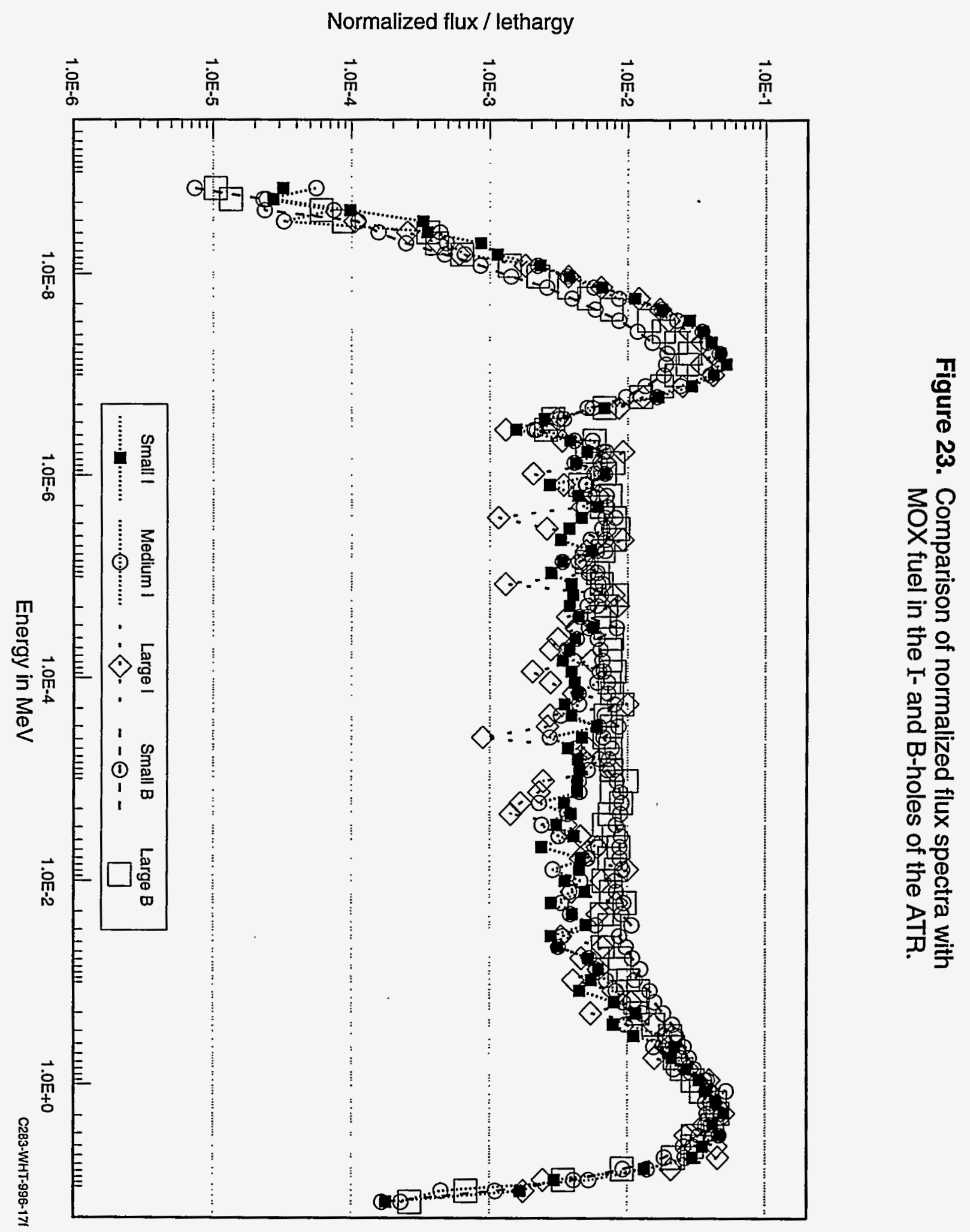


Figure 24. Comparison of normalized flux spectra with MOX fuel in the ATR, PWR, and CANDU.

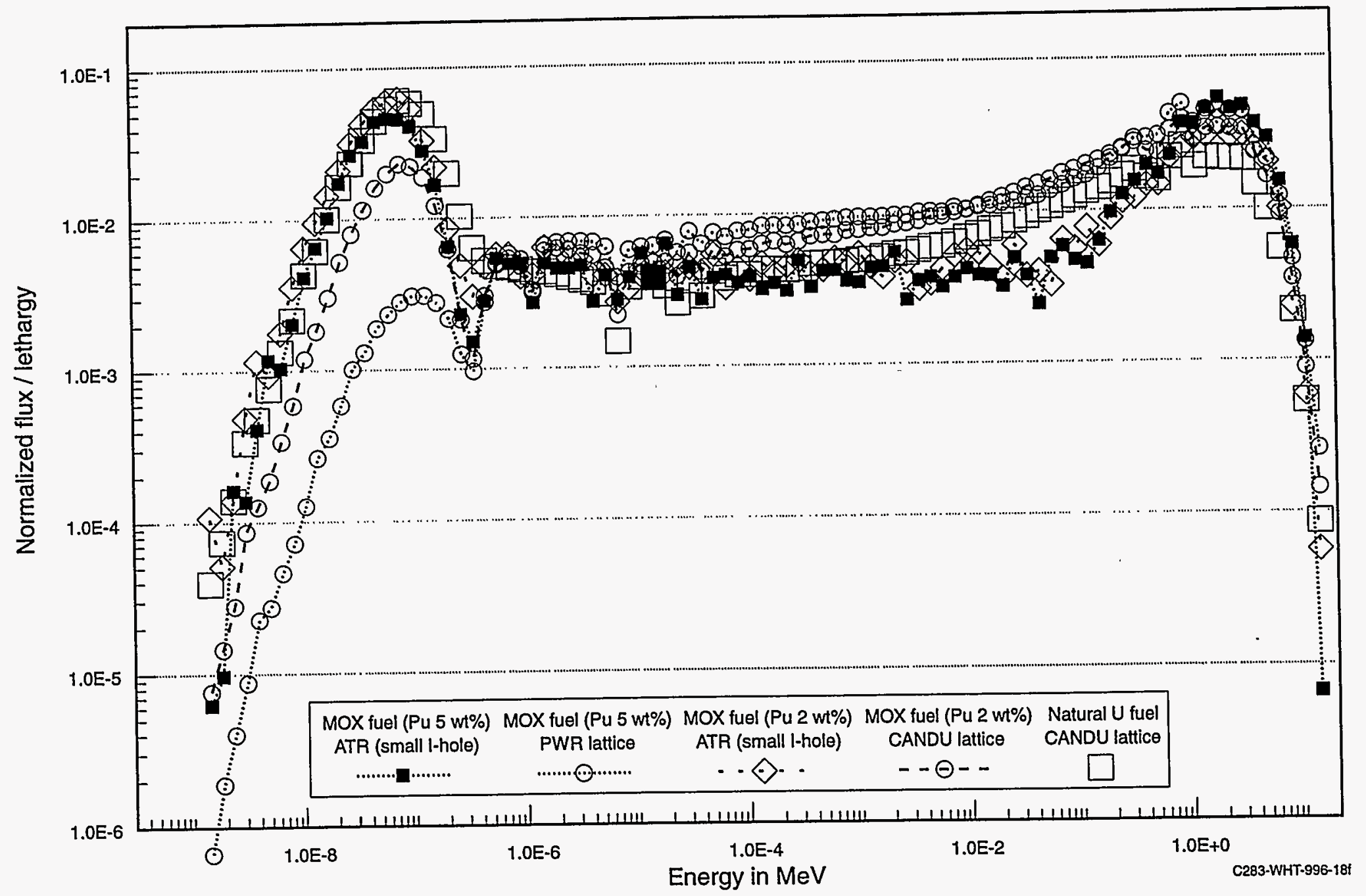




\subsection{TRANSPORTATION OF IRRADIATED MOX FUEL SPECIMENS}

The transport of irradiated MOX fuel specimens necessarily begins at the irradiating facility. The selection of the transport packaging depends on the characteristics of the specimens, and on the facilities involved.

\subsection{Characteristics of the Specimens}

In general, all radioactive materials transport packagings function to protect the general public, the environment, and occupational workers from the hazards associated with radioactive materials. Protection is afforded through specific design features relative to shielding, containment, and, for fissile materials, subcriticality control.

The characteristics of the radioactive material dictate the specific design features a transport packaging must have in order to safely transport the material. These characteristics are:

- Chemical and physical form, and

- Radionuclide inventory and respective activities.

The chemical constituents of the radioactive contents must be known in order to evaluate compatibility. Any constituents that would degrade a packaging's effectiveness in performing its functional responsibilities must be identified. Physical form(s) must be known in order to evaluate containment.

The radionuclide inventory and respective activities must be known in order to evaluate shielding, containment, and subcriticality control. In addition, the radionuclide inventory and activities determine the category into which the radioactive material fits, which then determines the packaging(s) authorized for this transport.

The determination of categories and authorized packagings is described in the Department of Transportation's Hazardous Materials Regulations (HMR, also known as DOT Regs or 49CFR). A category is based on an activity called $A_{2}$. Activities above $A_{2}$ or equivalent $A_{2}$, are called type-B quantities. The HMR lists packagings authorized for the transport of type-B quantities of radioactive material. 
A subsidiary category also exists for those radionuclides defined (by the HMR) as fissile $\left.{ }^{238} \mathrm{Pu},{ }^{239} \mathrm{Pu},{ }^{241} \mathrm{Pu},{ }^{233} \mathrm{U},{ }^{235} \mathrm{U}\right)$. A mass quantity greater than 15 grams of these radionuclides is considered to be a fissile quantity. The HMR lists packagings authorized for the transport of fissile quantities of radioactive material.

There are standard packaging authorized by the HMR for specific type-B quantities and fissile contents, but the majority of type-B fissile packagings are those licensed by the Nuclear Regulatory Commission (NRC) in accordance with their packaging standards (codified in 10CFR71). The NRC also imposes in its regulations an additional requirement for packages transporting plutonium (other than reactor fuel elements or plutonium metal or metal alloy). For activities greater than 20 curies, the packaging is to have two independent containment systems fully qualified to the 10CFR71 design standards.

Relative to MOX fuel irradiation specimens, the important radiological properties will be the presence of the plutonium radionuclides, principally ${ }^{239} \mathrm{Pu}$, and the presence of fission and neutron activation products whose decay schemes include gamma radiation of sufficient strength and activity to require shielding.

The HMR (and NRC) $\mathrm{A}_{2}$ activity for ${ }^{239} \mathrm{Pu}$ is 5.4 millicuries. At a specific activity of 0.062 curies per gram, it takes 930 millicuries of ${ }^{239} \mathrm{Pu}$ to reach 15 grams, and 322 grams to reach 20 curies. Of these three threshold activities, the latter, 322 grams $/ 20$ curies, represents the most significant challenge to packaging designs. These threshold activities will be different for the actual "mixture" of radionuclides that will be present. All the radionuclides must be counted for the calculation of the equivalent $A_{2}$, all the fissile radionuclides must be counted for the 15-gram fissile limit, and all the plutonium radionuclides must be counted for the 20-curie plutonium limit.

Consequently, when designing the irradiation experiments, consideration should be afforded to these thresholds, especially the 20-curie threshold, because it cannot be argued that the radiation specimens are reactor fuel elements in the classic sense. Metal and metal alloy usually refer to unirradiated plutonium; hence, this exception will likewise be hard to argue. There are not very many licensed packagings that have the double containment system for plutonium, especially those that require shielding.

The HMR (and NRC) regulatory limit for radiation fields external to the transport packaging is 200 millirem per hour at the surface of the packaging, or if the conveyance is a closed transport vehicle and no other cargo is carried, $1000 \mathrm{mR} / \mathrm{hr}$ at the packaging's surface or 200 $\mathrm{mR} / \mathrm{hr}$ at the surface of the conveyance. 
Shielding should not be much of a concern when considering that a number of packagings exist for transporting spent fuel assemblies. However, as discussed in Section 7.2, the interface capabilities of the shipping and receiving facilities will limit this packaging selection.

\subsection{Facilities}

The irradiation facility is the ATR, which is within the Test Reactor Area (TRA) "facility" within the security access-controlled boundary of the INEL "site." If the post-irradiation examination (PIE) facility is located within the TRA, the transport is an intra-facility transport. If the PIE facility is not at the TRA, but at another facility within the security access-controlled boundary of the INEL, the transport is an on-site transport. If the PIE facility is outside the security access-controlled boundary, the transport is an off-site transport.

Since the TRA is a Department of Energy (DOE) facility, transport from the ATR is governed by the DOE order on the transport of hazardous materials, DOE Order 460.1, which mandates that off-site hazardous materials transport be conducted in accordance with all federal (DOT's HMR), state, and local regulations. Consequently, selection from the HMR's list of authorized packagings is germane.

The selection of the transport packaging must account for the facility/transport packaging interfaces at both the shipping and receiving facilities in addition to the radiological characteristics of the proposed contents. Since the ATR is the shipping facility, the following limitations will be placed on the transport packaging:

- Underwater-loading-capable in the ATR working canal;

- Suitably short length to keep the irradiated specimens under a sufficient depth of water (for shielding), when loading vertically in the 20 -foot deep canal; and

- No more than 20 tons lifted weight (ATR Technical Specification limitation).

The weight limitation removes commercial-sized spent fuel transport packagings from consideration as suitable candidates, thus leaving only smaller sized packagings. Therefore, consideration to size or ease of disassembly (in the canal) should also be included in designing the irradiation experiments. 
The receiving facility interface requirements must likewise be considered. The receiving facility may not be limited to only the PIE facility. Assuming that an ultimate disposal is necessary at a facility other than the PIE facility, the ultimate disposal facility's acceptance criteria for receipt must be addressed.

\subsection{Transport Packaging Selection Summary}

The transport packaging will be selected based on:

- The radiological characterization of the irradiated MOX fuel specimens, and

- The interface requirements of both the shipping (ATR) and receiving facilities.

Packaging and transport considerations, and ultimate disposal considerations, should be among the inputs to the design of the MOX fuel irradiation specimen(s).

There may not exist a transport packaging that can transport the MOX specimens under the content restrictions and limitations of the packaging's NRC Certificate of Compliance. This would require that an amendment be submitted to the $\mathrm{NRC}$ requesting the requisite change to the Certificate of Compliance to include irradiated MOX fuel specimens as authorized contents. 


\section{REFERENCES}

1. J. W. Sterbentz, J. M. Ryskamp, S. C. Mason, and G. S. Chang, "Mixed Oxide Fuels Testing in the Advanced Test Reactor," Trans. Am. Nucl. Soc., 11,301 (1994).

2. W. K. Terry, J. M. Ryskamp, J. W. Sterbentz, G. S. Chang, R. G. Ambrosek, and S. L. Hayes, "Opportunities for Mixed Oxide Fuel Testing in the Advanced Test Reactor to Support Plutonium Disposition," INEL-95/0384, Idaho National Engineering Laboratory (1995).

3. J. M. Ryskamp, J. W. Sterbentz, G. S. Chang, W. K. Terry, R. G. Ambrosek, and S. L. Hayes, "Mixed Oxide Fuels Testing in the Advanced Test Reactor to Support Plutonium Disposition," INEL-95/0459, Idaho National Engineering Laboratory (1995).

4. J. M. Ryskamp, J. W. Sterbentz, G. S. Chang, and W. K. Terry, "Mixed Oxide Fuel Testing Capabilities in the Advanced Test Reactor," Proceedings of the ASME-JSME 4th International Conference on Nuclear Engineering, New Orleans, LA, March 10-14, 1996, Vol. 4, 477 (1996).

5. National Academy of Sciences, Committee on International Security and Arms Control, Management and Disposition of Excess Weapons Plutonium, National Academy Press, 1994, and Management and Disposition of Excess Weapons Plutonium: Reactor-Related Options, 1995.

6. "Storage and Disposition of Weapons-Usable Fissile Materials Draft Programmatic Environmental Impact Statement," DOE/EIS-0229-D, U.S. Department of Energy (February 1996).

7. "Technical Summary Report for Surplus Weapons-Usable Plutonium Disposition, Rev. 0," U.S. Department of Energy (July 1996).

8. H. R. Cantor and W. V. Danker, "Overview of DOE Fissile Materials Disposition Program," DOE Spent Nuclear Fuel and Fissile Material Management, Reno, NV June 16-20, 1996.

9. J. J. Buksa, S. L. Eaton, and J. W. Toevs, "Disposition of Plutonium as Mixed Oxide Nuclear Fuel," Proceedings of the ASME-JSME 4th International Conference on Nuclear Engineering, New Orleans, LA, March 10-14, 1996, Vol. 4, 453 (1996).

10. W. F. Naughton, "Disposition of Weapons-Grade Plutonium in Commercial Light-Water Reactors," Nuclear News (August 1996).

11. R. T. Primm III, "Assessment of the Technical Viability of Reactor Options for Plutonium Disposition," DOE Spent Nuclear Fuel and Fissile Material Management, Reno, NV, June 1620, 1996, 10 (1996).

12. K. K. S. Pillay, "Plutonium Management for the Future," DOE Spent Nuclear Fuel and Fissile Material Management, Reno, NV, June 16-20, 1996, 3 (1996).

13. G. Lebastard and R. Moyer, "The Disposition of Weapons Plutonium in MOX Fuel," Proceedings of the International Topical Meeting on Nuclear and Hazardous Waste Management, Spectrum '96, Seattle, WA August 18-23, 1996, 2063 (1996). 
14. C. A. Beard, J. J. Buksa, K. Chidester, S. L. Eaton, F. E. Motley, and D. A. Siebe, "Evaluation of Existing United States' Facilities for Use as a Mixed-Oxide (MOX) Fuel Fabrication Facility for Plutonium Disposition," Proceedings of the ASME-JSME 4th International Conference on Nuclear Engineering, New Orleans, LA, March 10-14, 1996, Vol. 4, 459 (1996).

15. H. T. Blair and K. B. Ramsey, "Experience Making Mixed Oxide Fuel with Plutonium from Dismantled Weapons, "Proceedings of the ASME-JSME 4th International Conference on Nuclear Engineering, New Orleans, LA, March 10-14, 1996, Vol. 4, 465 (1996).

16. J. Bader, F. Shallo, and M. Stern, "MOX Fuel Fabrication Utilizing European Technology," Trans. Am. Nucl. Soc., 74, 85 (1996).

17. T. Bullock, "Issues Related to Reutilized U.S. Mixed-Oxide Capability," Trans. Am. Nucl. Soc., 74, 84 (1996).

18. E. H. Ehrlich, "Capability of the Advanced Boiling Water Reactor to Operate with MOX Fuel," Proceedings of the ASME-JSME 4th International Conference on Nuclear Engineering, New Orleans, LA, March 10-14, 1996, Vol. 4, 557 (1996).

19. M. Yagi, M. Nagano, and S. Sakurai, "Feasibility Study on ABWR Full MOX Core," Trans. Am. Nucl. Soc., 74, 329 (1996).

20. P. Chodak III, M. Driscoll, and N. Todreas, "A Pressurized Water Reactor Deep Burn Plutonium Fuel Cycle," Proceedings of the ASME-JSME 4th International Conference on Nuclear Engineering, New Orleans, LA, March 10-14, 1996, Vol. 4, 549 (1996).

21. P. Chodak III, "Destruction of Plutonium Using Non-Uranium Fuels in Pressurized Water Reactor Peripheral Assemblies," PhD Dissertation, Massachusetts Institute of Technology (1996).

22. C. V. Lombardi and A. Mazzola, "Use of Plutonium Stockpiles in Uranium-Free Fuel for Energy Production," DOE Spent Nuclear Fuel and Fissile Material Management, Reno, NV, June 16-20, 1996, 19 (1996).

23. K. B. Ramsey and H. T. Blair, "Fabrication of a Non-Fertile Fuel for the Disposition of Weapons Plutonium in Water Reactors," Proceedings of the ASME-JSME 4th International Conference on Nuclear Engineering, New Orleans, LA, March 10-14, 1996, Vol. 4, 499 (1996)

24. ATR Technical Specifications, issue 089, Idaho National Engineering Laboratory, May 8, 1996.

25. ASME Boiler and Pressure Vessel Code, Section III, American Society of Mechanical Engineers, 1992 Addenda.

26. J. Briesmeister (Editor), "MCNP--A General Monte Carlo N-Particle Transport Code, Version 4A," LA-12625-M, Rev. 2, Los Alamos National Laboratory (1993).

27. S. S. Kim, S. N. Jahshan, and R. B. Nielson, "MCNP Full-Core Modeling of the Advanced Test Reactor," Trans. Am. Nucl. Soc., $\underline{68,} 434$ (1993).

28. ABAQUS User's Manual, Version 5.3, Hibbit, Karlsson \& Sorenson, Inc., 1993.

29. A. G. Croff, "ORIGEN2: A Versatile Computer Code for Calculating the Nuclide Compositions and Characteristics of Nuclear Materials," Nuclear Technology, 62, 335 (1983). 
30. Westinghouse Electric Corp., "Plutonium Disposition Study, Phase II Final Report, Volume I," DOE/SF/19683-5, April 30,1994.

31. Westinghouse Electric Corp., "Pressurized Water Reactor RESAR-3S," Chapter 4, Figure 4.36 (1975).

32. G. S. Chang, "Detailed Pin-by-Pin MCNP Model for Pressurized Water Reactor Core Analysis," Trans. Am. Nucl. Soc., $\underline{72}, 365$.

33. G. S. Chang, "Burnup-Dependent One-Group Cross Section of MOX Fuel for ORIGEN2," Trans. Am. Nucl. Soc., 72 , 391.

34. Reference Guide, Lotus 1-2-3 for UNIX, version 1.2, Lotus Development Corporation, Cambridge, MA, 1992.

35. A. G. Croff, M. A. Bjerke, G. W. Morrision, and L. M. Petrie, "Revised Uranium-Plutonium Cycle PWR and BWR Models for the ORIGEN Computer Code," ORNL/TM-6051, Oak Ridge National Laboratory (1978). 